Universidad Nacional de La Plata

Facultad de Periodismo y Comunicación Social

Maestría en Comunicación y Criminología Mediática

\title{
Tesis
}

\section{La construcción de la figura del "Loco peligroso" en los medios de comunicación impresos diario El Día y diario Hoy}

Exploración del concepto de peligrosidad definido por el derecho, en lo que respecta a las personas con padecimientos mentales que realizan una acción antijurídica y su vinculación con la construcción mediática de la figura del "loco peligroso".

Directora: Mgter. María Elisa Ghea

Codirector: Lic. Xavier Oñativia

Alumna: Lic. Romina Ailín Urios

Noviembre de 2018 


\section{AGRADECIMIENTOS}

En primer lugar, deseo agradecer profundamente a la Educación Pública y a Universidad Nacional de La Plata, por permitirme realizar este trayecto académico en el cual me he enriquecido no sólo en lo que tiene que ver con mi formación profesional, sino también ha fomentado un crecimiento personal.

Agradecer a todas las personas que han colaborado, contribuido y acompañado este proceso de elaboración de tesis. Primeramente, a mi directora, María Elisa Ghea, por su generosidad y paciencia en cada tramo de este camino, siempre cerca y atenta en este proceso de aprendizajes.

A Xavier Oñativia, el co-director de este trabajo, por su lectura criteriosa y valiosos aportes, también por su aliento constante y por leer, discutir y problematizar cada apartado y de ese modo contribuir en la construcción de esta tesis.

A mis compañeros de Maestría, con los que aprendí muchísimo, no solamente de contenidos y conceptos, sino de la praxis, y de la necesidad y riqueza de la interdisciplina para pensar en los múltiples atravesamientos de las situaciones desde un punto de vista crítico y no ingenuo, lo que permite una mejor mirada e intervención. También por acompañarme en este proceso, en el que más de una vez acudí con consultas específicas del campo del derecho y siempre hubo una respuesta $-\mathrm{y}$ en ocasiones más preguntas, para seguir relanzando el debate y análisis-. A ellos gracias miles por su aporte siempre desinteresado y generoso.

A mi familia: San, Lu y Lauti; y amigos, principalmente Marien y Astrid que fueron compañía, soporte, contención y aliento. Los amo infinitamente.

$Y$ a todos aquellos que estuvieron acompañando este proceso de alguna manera, sepan que también forman parte del trabajo que viene a continuación.

Gracias! 


\section{ÍNDICE}

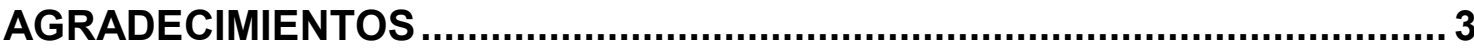

ÍNDICE

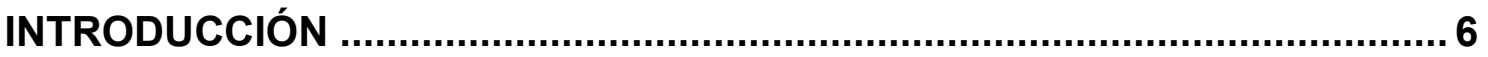

Motivaciones profesionales en la temática abordada............................... 7

Formulación y reformulación del tema de investigación ............................. 10

Revisión de los planteos originales del plan de tesis ............................... 11

Descubrimientos, novedades, oportunidades y nuevos interrogantes .......... 14

Nuevos interrogantes, nuevos objetivos ........................................... 18

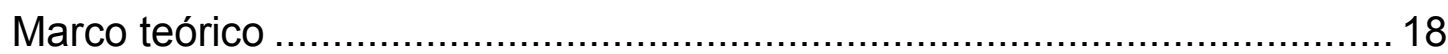

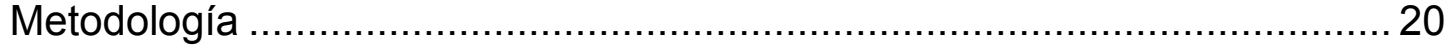

LOS MEDIOS MASIVOS DE COMUNICACIÓN COMO SEGMENTOS DEL

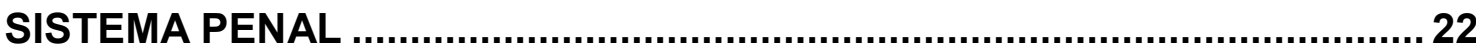

Historizar para conocer .................................................................... 23

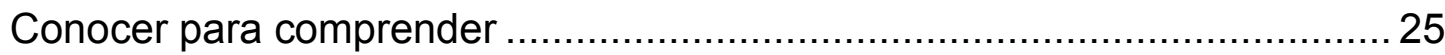

Comprender para avanzar ............................................................. 26

Los medios de comunicación como productores de subjetividades............. 27

Sobre la necesidad del contra discurso ............................................... 37

LAS CORRIENTES CRIMINOLÓGICAS Y LA NOCIÓN DE CASTIGO .......... 39

Las corrientes criminológicas y la noción clásica de castigo...................... 40

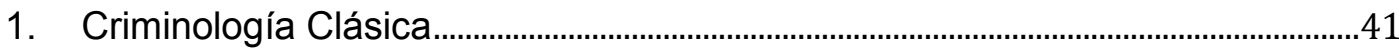

2. Escuela Positivista ................................................................................................................

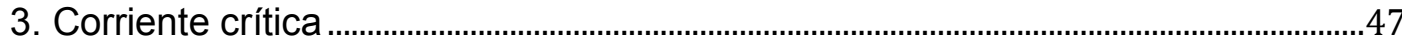

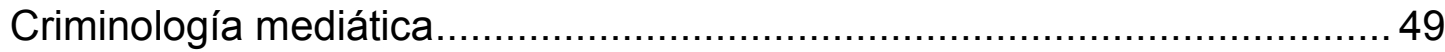

TEORÍA DEL DELITO Y DE LA PENA ................................................... 56

El poder punitivo y la pena ............................................................ 57

El concepto de "delito" y sus elementos................................................. 61

Elementos constitutivos del delito ..................................................... 62

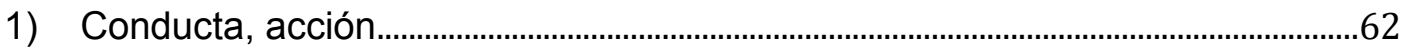

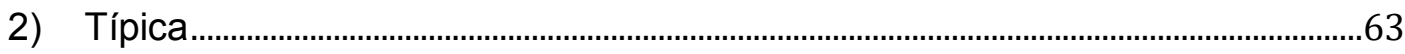

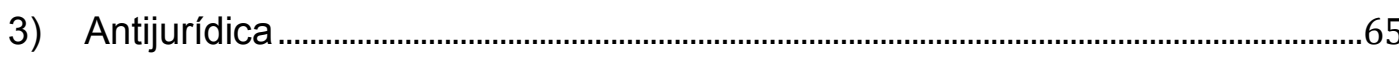


4) Culpable. . .66

El caso de la inimputabilidad: no culpabilidad, ¿no pena? .........................6 68

Delito y vulnerabilidad ............................................................ 71

LA NOCIÓN DE "PELIGROSIDAD" COMO JUSTIFICATIVO PARA LA APLICACIÓN DE MEDIDAS DE SEGURIDAD A PERSONAS CON PADECIMIENTO MENTAL ..................................................................... 75

Sobre el concepto de "peligrosidad" en el derecho .................................. 76 ¿Qué relación puede establecerse entre el concepto de "peligrosidad" y la medida de seguridad desde el Derecho?.

¿Cómo se juega el concepto de peligrosidad en la especificidad del padecimiento mental?

De la locura al padecimiento mental 85

LA CONSTRUCCIÓN DE LA FIGURA DEL “LOCO PELIGROSO” EN EL SEGUIMIENTO DE UNA NOTICIA PUBLICADA POR EL DIARIO EL DÍA DE LA PLATA (Y PUBLICACIONES POSTERIORES REALIZADAS POR EL DIARIO HOY) 91

Análisis e interrogantes del abordaje mediático del caso del "loco del cuchillo" 129

CONCLUSIONES 134 


\section{INTRODUCCIÓN}

Palabras clave: "Loco peligroso". Criminología. Medios de comunicación.

Como licenciada en Psicología, a partir de mis estudios de grado y por mi inserción laboral como docente en la Cátedra de Psicología Forense de la Facultad de Psicología de la Universidad Nacional de La Plata e investigadora y extensionista en el ámbito forense-criminológico, esta tesis constituye un eslabón más de una trayectoria que se ha inscripto siempre desde el interés y la necesidad de profundizar en la temática.

El haber realizado la cursada de la Maestría en Comunicación y Criminología Mediática -Facultad de Periodismo y Comunicación social, UNLP, me permitió empezar a problematizar sobre la construcción que hacen los medios de las subjetividades, y además, las técnicas periodísticas de interpretación de los hechos; el valor de las palabras, la jerarquización de la información que los mismos realizan para construir discursos que influyen en las miradas sobre el mundo que nos rodea y que se instalan en el sentido común.

Cuando decidí cursar la maestría pensé en la relación entre contenidos académicos y mi campo laboral. Particularmente, me atrajo su planteo presente en el Perfil de la propuesta de la Maestría en Comunicación y Criminología Mediática, ${ }^{i}$ con respecto a que

La Maestría en Comunicación y Criminología Mediática propone constituirse como un espacio de formación, reflexión e investigación respecto del fenómeno que involucra a la comunicación en el proceso de expansión del poder punitivo. El eje que articula su propuesta curricular, las instancias de debate que promueve y las prácticas de investigación que contempla, es aquel que da cuenta de la historia, los contextos y los mecanismos que posibilitan un proceso de criminalización creciente, atendiendo a la dimensión comunicacional y de derechos humanos respecto del problema. 
También me llevó a inscribirme el abordaje de análisis y recorrido teórico académico que tienen en cuenta el contexto en el cual los temas presentes inciden en, por ejemplo, el desarrollo y construcción de políticas públicas,

La complejidad de los fenómenos sociales y los actores que intervienen en los mismos ha alcanzado un nivel de desarrollo acorde al actual momento capitalista global de los servicios, las tecnologías y la comunicación. Y es precisamente esta última una de las determinantes en la construcción del actual imaginario social a través de los medios masivos de comunicación.

Es en este sentido, que en este trabajo se aborda la cuestión sobre "La construcción de la figura del "Loco Peligroso" en los medios de comunicación impresos ("El Día" y "Hoy")", los cuales se tomarán como caso testigo. Para ello parto de los aportes que me han otorgado las diversas asignaturas que he cursado en la Maestría en Comunicación y Criminología Mediática.

\section{Motivaciones profesionales en la temática abordada}

En mi historia académica y de investigación, el abordaje analítico y de investigación sobre la Criminología siempre significó un ámbito de interés y de indagación permanente. Fue tema de desarrollo durante la exploración prevista para el sistema de adscripción a la docencia universitaria en la Cátedra de Psicología Forense de la Facultad de Psicología de la Universidad Nacional de La Plata y ha sido punto de partida para la confección de la tesis de la Especialización en Psicología Jurídica y/o Forense realizada en el Colegio de Psicólogos de la Provincia de Buenos Aires, Distrito XI, trabajo denominado "Culpa, responsabilidad (subjetiva) y pena". El escrito hace referencia al entrecruzamiento de los discursos jurídico y psicoanalítico en lo que tiene que ver con la criminalidad en lo atinente al concepto de responsabilidad.

Ese mismo interés me llevó a realizar la Maestría en Comunicación y Criminología Mediática en la Facultad de Periodismo y Comunicación Social de 
la Universidad Nacional de La Plata, para poder seguir profundizando y complejizando el estudio que sobre el tema he venido realizando.

El marco conceptual aportado por la Maestría y la posibilidad de cursar con profesionales de distintas disciplinas fue un aporte para ampliar no sólo mis conocimientos sobre la temática sino, además, me permitió interactuar con esos otros saberes provenientes de diversos campos y de los cuales me he nutrido durante la cursada a través del intercambio con el resto de los cursantes.

Mi inclusión en un proyecto de investigación acreditado por la UNLP "Prácticas y discursos en torno a la inimputabilidad en contexto de encierro penitenciario: exploración de la noción de peligrosidad en medidas de seguridad en el marco de la Ley Nacional de Salud Mental", en el marco del PPID finalizado en julio de 2018, me permitió delimitar un tema de estudio para desarrollar en mi tesis de Maestría.

Sobre este particular es importante conocer el marco legal vigente que regula tanto el ámbito del Derecho Penal como la Salud Mental y su modo de vinculación con los Medios de Comunicación. Atender a la historicidad de la Legislación permite vislumbrar que muchas veces, más allá de encontrarnos inmersos en un Paradigma Humanista, pueden encontrarse resabios de un Paradigma Anterior (positivista) en las prácticas.

Es posible afirmar que existe una distancia entre los discursos y las prácticas que sólo se comprende por medio de la historización. Además, no debe perderse de vista que las leyes producen un efecto en la subjetividad de la población, en tanto son instrumentos, postula Freud en "Tótem y Tabú" (1991) que permiten regular los vínculos. Son control social necesario para habitar en la cultura. Por esto las leyes constituyen el contexto necesario a tener en cuenta para el desarrollo de este trabajo. En las leyes también se encuentra el orden del discurso del cual Michel Foucault tanto se ha encargado de analizar. 
Lo planteado se visualiza en las tensiones que se encuentran presentes entre los discursos y las prácticas vigentes en lo que respecta a las personas con padecimientos mentales que se encuentran en contextos de encierro, o que han cometido una acción antijurídica, es decir, aquellas personas que se encuentran alojadas en instituciones penitenciarias bajo el artículo 34 del Código Penal argentino (inimputabilidad). Lo que interesa en este punto es indagar cómo se juega el concepto de peligrosidad en los medios de comunicación al hacer referencia al -y contribuir en la construcción del- "loco peligroso".

La Ley Nacional de Salud Mental N. ${ }^{\circ} 26.657$ sancionada durante el gobierno de Cristina Fernández de Kirchner, establece en su Capítulo I, "Derechos y garantías", y sostiene en su artículo primero que

La presente ley tiene por objeto asegurar el derecho a la protección de la salud mental de todas las personas, y el pleno goce de los derechos humanos de aquellas con padecimiento mental que se encuentran en el territorio nacional, reconocidos en los instrumentos internacionales de derechos humanos, con jerarquía constitucional, sin perjuicio de las regulaciones más beneficiosas que para la protección de estos derechos puedan establecer las provincias y la Ciudad Autónoma de Buenos Aires.

En su Capítulo II, "Definiciones", se encuentra el Art. 3 de la Ley, que enuncia qué se entiende por salud mental, el cual es claro en cuanto a quiénes alcanza.

En el marco de la presente ley se reconoce a la salud mental como un proceso determinado por componentes históricos, socio-económicos, culturales, biológicos y psicológicos, cuya preservación y mejoramiento implica una dinámica de construcción social vinculada a la concreción de los derechos humanos y sociales de toda persona. Se debe partir de la presunción de capacidad de todas las personas. En ningún caso puede hacerse diagnóstico en el campo de la salud mental sobre la base exclusiva de: 
a) Status político, socioeconómico, pertenencia a un grupo cultural, racial o religioso. b) Demandas familiares, laborales, falta de conformidad o adecuación con valores morales, sociales, culturales, políticos o creencias religiosas prevalecientes en la comunidad donde vive la persona. c) Elección o identidad sexual. d) La mera existencia de antecedentes de tratamiento u hospitalización.

Es decir que la Ley de Salud Mental, se inscribe como una normativa que contempla la garantía y respeto de derechos en salud mental para toda la población del país haciendo mayor énfasis en la protección de aquellas personas que presentan un padecimiento mental grave por considerarlos en situación de mayor vulnerabilidad. Es una ley que lejos de ser exclusiva para un sector de la población, se hace extensiva a todas las personas.

Pensar, reflexionar y conceptualizar los atravesamientos y entrecruzamientos entre Criminología, Salud Mental y Medios de Comunicación, tiene por resultado el trabajo de investigación que continúa.

\section{Formulación y reformulación del tema de investigación}

Al presentar el Plan de Tesis en octubre de 2016, aprobado por Resolución en el expediente 2700 - 006844 / 17 - 000, Facultad de Periodismo y Comunicación Social, Maestría Criminología mediática, La Plata, octubre de 2016; planteaba como tema la "Exploración del concepto de Peligrosidad en las tensiones presentes entre los discursos y las prácticas vigentes, en lo que respecta a las personas con padecimientos mentales en contextos de encierro".

Todo planteo de un tema por investigar tiene diversos momentos. En principio se reflexiona sobre éste; se construye un objeto de estudio posible de abordaje y luego se comienza a hacer la investigación en sí. Al momento de comenzar con ésta, con el rastreo de material y acercamiento al campo, intervinieron diversas variables que posibilitaron realizar un nuevo recorte sobre el objeto de estudio, así como también, reformular las preguntas que me 
había hecho al momento de escribir mi plan de tesis y el planteamiento de nuevos y diversos interrogantes.

El plan de tesis fue confeccionado desde un interés planteado desde lo teórico y el conocimiento a priori del campo de investigación, pero el acercamiento al mismo en forma real y concreta permitió otro tipo de relación con él, que en un movimiento dialéctico llevó a un preguntar y repreguntar sobre nuevos aspectos antes impensables.

También algunos obstáculos encontrados que se vinculan con la realidad influyeron en esta modificación del plan original que, entre otros, a continuación, se enumeran.

\section{Revisión de los planteos originales del plan de tesis}

La mayoría de los obstáculos que se presentaron al momento de comenzar con la recopilación de información que sería insumo para esta tesis, se dieron en el campo concreto de exploración -lo institucional- y, por otro lado, con cambios a nivel legislativo que han puesto a la Ley Nacional de Salud Mental en jaque, como por ejemplo la presentación del Decreto Reglamentario a la Ley N. ${ }^{\circ} 26.657$ del 15 de septiembre de $2017^{\mathrm{ii}}$, que resulta en su análisis una derogación encubierta.

El proyecto de investigación del que formo parte en la Facultad de Psicología brindaría el material correspondiente al estudio de campo en la Unidad Penitenciaria N. ${ }^{\circ} 34$ de La Plata, Provincia de Buenos Aires ${ }^{\text {iii }}$, que aloja a sujetos detenidos bajo medida de seguridad por inimputabilidad y sobreseídos, mediante entrevistas a diversos actores institucionales, el análisis de materiales documentales tales como historias clínicas, informes técnicocriminológicos, entre otros.

Al momento de comenzar el recorrido de recopilación de datos mucho de lo esperado no fue posible por diversas vicisitudes en lo institucional: desde cambios en el personal directivo, hasta traslado y suspensión de personal 
interno. Las dificultades de acceso a fuentes documentales (legajos, registros e historias clínicas) de la institución del Sistema Penitenciario Bonaerense, estuvieron asociadas al proceso de intervención del servicio iniciado en el mes de octubre del año 2016.

La Ley Nacional de Salud Mental N. ${ }^{\circ} 26.657$, sancionada en el año 2010 y reglamentada en 2013, a partir del cambio de gobierno comienza a ser debilitada por falta de financiamiento para la creación y sostenimiento de dispositivos alternativos a la internación manicomial; por falta de capacitación al personal, traslado de profesionales a otras áreas desmembrando los equipos interdisciplinarios, falta de camas para atención en salud mental en hospitales generales, desfinanciamiento en recursos destinados a movilidad para el seguimiento y acompañamiento de personas externadas del hospital neuropsiquiátrico, entre otros.

Se detiene el proceso progresivo de implementación iniciado en la gestión precedente y comienzan a producirse retrocesos y contrasentidos con respecto al paradigma de Derechos Humanos y Salud Mental que constituían los vectores y fundamentos de la Ley Nacional.

En segundo lugar, hacia agosto de 2017 se produce un intento de reformulación del decreto reglamentario de la Ley N ${ }^{\circ} 26.657$ por parte del Poder Ejecutivo Nacional que, sin pasar por las instancias legislativas correspondientes, pretendió impulsar el retroceso del proceso transformador en el campo de salud mental, cuyos componentes centrales fueron: la introducción de un cambio crítico en la concepción de salud mental, la obstaculización y ruptura de los procesos de trabajo interdisciplinario, el avance de la concepción medicalizante asociada al fármaco como sinónimo de terapéutica con la correlativa mayor injerencia de la industria farmacéutica.

También se acompañó con el descrédito de las competencias de otros profesionales por fuera de los médicos psiquiatras para ejercer cargos de jefatura de servicios; la interrupción de las políticas conducentes a la sustitución y cierre progresivo de los hospitales psiquiátricos bajo el modelo 
asilar manicomial, como la construcción de viviendas dentro del predio del actual hospital neuropsiquiátrico Alejandro Korn ${ }^{\text {iv }}$, que lejos de constituir una restitución del derecho a vivir en comunidad, crea un nuevo dispositivo bajo la lógica manicomial y la limitación de las competencias asignadas al Órgano de Revisión como entidad de contralor.

Por último, se produce hacia el mes de octubre de 2016 la intervención del Servicio Penitenciario Bonaerense (SPB), momento en que la gobernadora de la provincia, María Eugenia Vidal, remueve a la cúpula que lo dirigía tras la fuga -y repercusión mediática- de los hermanos Lanattav y pone a un grupo de civiles encabezado por el subsecretario de Política Carcelaria Juan José Barica, a cargo de las cárceles de la provinciavi ${ }^{\mathrm{vi}}$ Los objetivos manifestados por la Gobernadora Vidal respecto de la asunción de esta nueva conducción en el SPB tuvieron que ver con realizar cambios en la estructura del organismo y un nuevo escalafón, más un programa de reinserción de los internos vii

Fue el momento de inicio de los traslados masivos y arbitrarios de profesionales y se comenzó con la realización de sumarios administrativos generalizados, tal como fuera mencionado en las entrevistas realizadas a los profesionales del SPB, en el marco del PPID. Este nuevo equipo estuvo a cargo hasta abril de 2018, momento en el cual se introduce una nueva modificación, asumiendo Xavier Areses ${ }^{\text {viii, }}$, quien hasta ese momento se desempeñaba como Subsecretario de Coordinación Legal, Técnica y Administrativa en el Ministerio de Justiciaix ${ }^{i x}$ que continúa en la línea de trabajo de la gestión anterior.

Debido a dicha intervención se comienzan a desarticular los procesos formativos y de trabajo del personal de salud y de seguridad lo cual impactó, directamente, en la salud individual de cada uno de los trabajadores e indirecta, pero sustancialmente, en los sujetos con padecimiento mental alojados en las diversas dependencias del sistema penitenciario provincial.

Todo esto conllevó a una dificultad en el acceso a la información institucional necesaria para abordar el tema planteado en mi propuesta de plan. 
En este particular pude realizar -junto con el equipo de investigación- algunas entrevistas a personal penitenciario previamente seleccionado por quien posibilitó el ingreso al penal. De todas maneras, si bien la documentación fue menos de la que se esperaba recoger, el material recabado resultó sustancioso en cuanto al contenido.

\section{Descubrimientos, novedades, oportunidades y nuevos interrogantes}

Lejos de desalentar el trabajo de investigación, las dificultades halladas se transformaron en oportunidades de exploración. Esto se dio sobre todo al comenzar a indagar diversas fuentes documentales, bibliográficas e informáticas, en las cuales fueron surgiendo aspectos hasta el momento no tenidos en cuenta -por no haber tenido contacto con ellos antes-, que permitieron abrir nuevos interrogantes.

También me centré en el por qué me había inscripto en una maestría que tiene como definición política académica en el Perfil de la propuesta, entre otras que

La compleja trama histórica que ha terminado por racionalizar y justificar la necesidad de punir involucra actores sociales múltiples que aún hoy participan en la institucionalización del castigo. La Comunicación Social interviene fuertemente en la actualización de un sistema que expulsa, estigmatiza y aprisiona sujetos en masa. La presente Maestría, desde una mirada crítica, apuesta al enriquecimiento de la capacitación con relación a este tema, cuál es la comunicación en su relación con la criminología, entendiendo que la Universidad pública no deja nunca de ser un territorio de sentidos en disputa, en el cual es posible y necesario acentuar la formación de sus actores hacia un espíritu crítico, democrático, inclusivo. Al mismo tiempo esta maestría apuesta a la producción de un conocimiento que aporte nuevos saberes al abolicionismo de la cultura represiva. 
En la búsqueda de información realizada por medios informáticos apareció el abordaje de un suceso desde un medio de comunicación que marcó un antes y un después en materia de indagación para esta tesis y que tiene íntima relación con el objetivo que se plantea la maestría en Comunicación y Criminología mediática de la FPyCS.

Es el caso del denominado por el canal del Grupo Clarín TN (Todo Noticias) el "Loco del hacha".

Se trata de un sujeto que en noviembre de 2014 destrozó el auto de un vecino con un hacha cansado de que estacionara su vehículo siempre en su entrada para autos. El titular dice "Furia en Palermo"x y la primera línea de la nota sostiene "Parece sacado de la ficción, pero pasó en la vida real", este carácter ficcional es el que tiñe al resto de la nota, marcando que Martín (quien usó el hacha), no actúa conforme correspondería a una persona "normal".

Si bien en la noticia se menciona que el vehículo del vecino tiene múltiples multas por mal estacionamiento y decenas de veces han remolcado el auto por obstruir el garaje de su vecino, el énfasis siempre está en Martín. No es en este artículo periodístico en el que se lo nomina como "el loco del hacha", sino en uno del día siguiente ${ }^{\mathrm{xi}}$, en el cual se amplían los datos.

Pero la información que se amplía no es del hecho ocurrido, sino de la historia de Martín, de quien se agrega que cumple dos probations, una por dispararle en una pierna a un sujeto y otra por tenencia de estupefacientes. Es esta "acumulación de causas" lo que lo ha convertido en "loco". Puede observarse cómo, si bien el abordaje de la información nunca es objetivo porque depende de quién selecciona y hace el tratamiento de esa información, lo que se hace es apelar a una respuesta subjetiva por parte del lector/espectador que será quien consumirá esa noticia como producto que se vende.

A partir de la lectura de esta nota periodística, se abrieron nuevos interrogantes: 
- ¿Tendrá influencia en la población esta construcción que los medios de comunicación realizan de la figura del "Loco peligroso" en el pedido, por ejemplo, de más mano dura para el caso de personas con padecimiento mental que cometen una acción antijurídica?

-El tratamiento que los medios de comunicación realizan sobre los casos de sujetos con padecimiento mental que realizan una acción antijurídica, ¿reforzará la idea de peligrosidad de esos sujetos en la población? ¿Cómo repercutirá esta "criminología mediática" -Zaffaroni- en el sistema penal, a la hora de imponer medidas de seguridad?

Como se verá, estas preguntas si bien están en relación con los interrogantes planteados en el plan de tesis originalmente presentado, se desvían hacia un recorte mucho más específico, que vincula en forma más acabada el recorrido realizado en la Maestría.

Otro aliciente para dar fortaleza a este recorte tiene que ver con un trabajo presentado en el 6to. Congreso Internacional de Investigación de la Facultad de Psicología (UNLP), donde en una mesa temática autoconvocada bajo el nombre "Locura y peligrosidad: interpelaciones desde la ley de salud mental", presentara una disertación bajo el título de CRIMINOLOGíA POSITIVISTA EN LOS MEDIOS: LA CONSTRUCCIÓN DEL "LOCO PELIGROSO". En ese trabajo, además de realizar un breve recorrido teórico en materia del concepto de peligrosidad en vinculación con las medidas de seguridad, se articuló con el caso de "El loco del hacha", con una excelente repercusión en el auditorio, lo que marcó la pauta del interés que la temática suscita en la comunidad académica, y su necesidad de desarrollo.

Para esto, lo que se plantea en esta tesis es, en principio, un recorrido teórico que dé cuenta de los principales conceptos que serán necesarios para realizar la articulación y análisis del tratamiento de un caso. Aquí lo que tenemos que explicar es que el marco teórico dará herramientas para poder analizar un caso desde el eje conceptual de la criminología mediática. 
Se toma para el análisis la lectura crítica de un medio impreso, atendiendo a la construcción que se realiza de la noticia, la selección y jerarquización de la información, el tratamiento del caso a lo largo del tiempo, las fuentes y las voces que se eligen para narrar la historia, fundamentalmente ¿qué se dice? y ¿cómo se dice? Preguntas que permiten analizar la posición del medio frente al hecho y la construcción de opinión pública: los efectos que tendrá en la población el tratamiento que se haga de la noticia. En diversas ocasiones puede observarse que, en la selección, construcción y tratamiento de una noticia, los medios se transforman en jueces y jurados, corriéndose de su función informativa.

Así, se seleccionó una noticia publicada en el Diario "El Día"xii, en la que aparece un hecho en que un sujeto presuntamente con padecimiento mental apuñaló a varias personas en la vía pública en la ciudad de Berisso ${ }^{\text {xiii }}$. Por la complejidad en lo que tiene que ver con el análisis de casos mediáticos, se seleccionó sólo uno y el abordaje del tratamiento informativo que realizó un solo medio, para poder acotar el análisis y hacerlo en profundidad. El Diario "Hoy", sólo se tomó para complementar el seguimiento del caso, una vez que dejó de tener visibilidad en "El Día".

Si bien el titular aportado para el mismo caso por el diario "Hoy" resulta por demás significativo y digno de análisis "Loco del cuchillo: apuñaló a cuatro personas en Berisso"xiv , se optó por trabajar con el diario "El Día", por ser un diario regional de vasta trayectoria -tiene más de cien años de existencia- y gran alcance -una tirada de más de 30.000 ejemplares diarios-. Cuenta también con su versión digital que es consultada y leída por personas de todo el país y su propia radio (FM 99.1 y "La Redonda"). Además, es un medio de referencia para emisoras de radio locales y regionales, las que suelen levantar sus noticias y reproducirlas en los espacios informativos. Todas estas características le permiten al medio informar su interpretación de los hechos que mediante su difusión y circulación de la información alcanza a un gran sector de la población que confía en la veracidad de lo transmitido, dando por cierto lo que titula y trata en sus páginas y demás espacios mediáticos. 


\section{Nuevos interrogantes, nuevos objetivos}

Frente a estos nuevos interrogantes surgió la necesidad de reformular los objetivos que se habían propuesto en el plan original y me planteé los siguientes:

Objetivo general: Explorar el concepto de peligrosidad en las tensiones presentes entre los discursos y las prácticas vigentes, en lo que respecta a las personas con padecimientos mentales que cometen una acción antijurídica.

Objetivos específicos

- Rastrear el tratamiento que realizan los medios de comunicación en los casos de inimputabilidad.

- Poner en tensión los resultados encontrados con lo normado en la Ley de Salud Mental N. ${ }^{\circ} 26.657$.

\section{Marco teórico}

Para poder realizar un acercamiento a los objetivos propuestos, la primera tarea fue situar conceptualmente el marco desde el cual se abordaron los temas pertinentes que permitieron arribar a un análisis del caso seleccionado para este trabajo. Para ello, el mayor insumo se encontró en las clases y materiales bibliográficos aportados por los seminarios cursados en la maestría, más otros que se incorporaron con posterioridad como ser textos actuales o que en virtud del tema propuesto resultaron con mayor especificidad para el desarrollo de esta tesis.

Se partió de la definición de Criminología, la cual se abordó desde las conceptualizaciones, principalmente, de Eugenio Zaffaroni, autor que acompañó toda la tesis por considerarlo imprescindible tanto en lo que tiene que ver con el marco conceptual de este trabajo, como en lo atinente al posicionamiento ideológico del abordaje analítico. 
Si bien se realizó un breve recorrido que intentó dar cuenta de qué es la Criminología como disciplina y los nuevos aportes en relación a la denominada "Criminología de los Derechos Humanos" (Aniyar de Castro, Codino, 2013), el punto de llegada tuvo que ver con puntualizar a la Criminología Mediática, como modalidad contemporánea de criminalización-victimización de sujetos. El libro "La palabra de los muertos" (2012), fue el que más elementos brindó para desentrañar este concepto.

Al trabajar en la interrelación de discursos entre lo jurídico y lo psicológico -salud mental-, se desarrolló un capítulo en el cual expliqué la teoría del delito y de la pena desde la ciencia jurídica (Zaffaroni, Alagia, Slokar, 2006), para luego abordar el artículo N. ${ }^{\circ} 34$ del Código Penal Argentino (declaración de inimputabilidad), que es el que permite relacionar ambos campos: ley y salud mental (Camargo, 2005; Domínguez Lostaló, 1995).

A partir de allí, se abordó el concepto de "peligrosidad" (uno de los ejes de este trabajo) y su vinculación con las medidas de seguridad que se imponen a las personas con padecimiento mental que han cometido una acción antijurídica: si el derecho dice que, por su situación de salud mental, no pueden ser punidos -porque serían, por ley, inimputables-, entonces no les cabría castigo alguno. Las medidas de seguridad, de acuerdo con el Código, deben ser "curativas". Sin embargo, pareciera que, en la realidad, la medida de seguridad, tal como se aplica en la práctica, resultaría ser lo mismo que una pena -porque se cumple en el mismo tipo de instituciones que estas últimas-, pero con el agravante de no tener un tiempo máximo de egreso pautado (Fallo Gramajo SCJN sobre Inconstitucionalidad del art. 52).

A estos elementos conceptuales tomados desde lo jurídico y desde lo psicológico, se añadieron los necesarios aportes desde el área de la Comunicación, ya que uno de los objetivos era analizar la construcción mediática de la figura del "loco peligroso". Así es como se conceptualizó acerca de qué es la comunicación, sus principales características y componentes, y se problematizó respecto a la época actual de la "hipercomunicación", que lejos de 
mantenernos cada vez más informados, pareciera que su función principal, es la de confundir y desinformar para dominar (Gramsci, 1970; Feinman, 2013).

Un autor que permitió hacer una "bisagra" entre el derecho y la comunicación es Darío Villarruel (2014), quien, en su doble inscripción desde ambas disciplinas, brindó herramientas para el pensamiento crítico del tratamiento mediático de muchos casos criminológicos.

Todo este recorrido, constituyó el insumo por el cual arribé al análisis crítico del tratamiento mediático del caso de "El loco del cuchillo", para lo cual se tomó la noticia tanto en su versión publicada en prensa, como la versión digital (desde el 2 de septiembre de 2016, que aparece la noticia, hasta noviembre de 2018. A partir del 8 de octubre de 2016 se tomó el diario "Hoy" para la continuidad del análisis, dado que, desde esa fecha hasta el 2 de noviembre de 2018, no volvió a publicarse nada sobre el caso en "El Día").

Luego, llegó el momento de las conclusiones, en donde se desarrollaron posibles respuestas a las preguntas que se plantearon al inicio de este trabajo -en forma total o parcial-. En ese recorrido, surgieron también nuevos interrogantes que permitieron dar dinamismo a la temática para continuar indagando y problematizando acerca del concepto de "peligrosidad" en el derecho y en los medios de comunicación, y de la figura del "loco peligroso".

\section{Metodología}

En esta investigación se utilizaron, sobre todo, herramientas de exploración y recolección de información cualitativas, entre ellas la observación, la entrevista y la revisión de material bibliográfico y documental (artículos periodísticos en diversos formatos).

La observación es una herramienta fundamental dado que no requiere de mayor destreza instrumental. Constituye el inicio de toda experiencia, ya que de ella parte el interés por lo que se quiere conocer, investigar, profundizar o analizar. 
Otro modo de conocer el mundo, además de la observación, es por medio de lo que se dice, por medio de los discursos que emergen constantemente en la vida diaria. La entrevista tiene el objetivo específico de que la gente hable sobre lo que sabe, piensa y cree acerca de un determinado tema.

También se utilizaron herramientas de análisis de discursos escritos, para medios gráficos para el seguimiento del caso antes mencionado. 


\section{LOS MEDIOS MASIVOS DE COMUNICACIÓN COMO SEGMENTOS DEL SISTEMA PENAL}

Palabras clave: comunicación, medios, hegemonía, criminología mediática

¿Qué es la comunicación? ¿Existe una sola respuesta para esa pregunta? ¿Qué es necesario para que haya comunicación? ¿Cuál es el papel de los medios de comunicación en la transmisión de ideología?

Se parte de la premisa de que los medios de comunicación no son un ente abstracto ni son ingenuos. Están en relación con el contexto social y cultural en el que se producen y enmarcan. Es esta característica central la que permite pensar que los medios son actores políticos y sociales, además de empresas y actores económicos, con sus intereses propios y que intervienen en cada contexto.

Los medios de comunicación no solo producen y reproducen sus propios discursos, sino que, así como visibilizan ciertas "realidades", también en su recorte, selección, construcción de la información y en su tratamiento, deciden qué decir y qué no decir.

En el capítulo 1 del programa Filosofía aguí \& ahora ${ }^{x v}$, de José Pablo Feinmann, el filósofo se pregunta sobre el poder de los medios de comunicación y la construcción de subjetividades. En este sentido sostiene que "el poder, tiene el poder de imponer la verdad. Y ¿por qué tener el poder de todos los medios de comunicación le permite al poder moldear las conciencias de los sujetos de una sociedad?" y se responde:

Porque la revolución comunicacional del imperio norteamericano ha sido justamente eso, una revolución comunicacional. Porque por medio de esa revolución condiciona, conforma, forma las subjetividades de los receptores. Hace de los demás un enorme mundo de receptores de la verdad que emite ese inmenso poder comunicacional. 
¿Cuáles son los efectos sociales, culturales, subjetivos que producen los medios de comunicación? Y, concomitantemente, con relación al espacio que en la actualidad ocupan las noticias "policiales" y criminológicas en la programación de los canales de televisión y en la prensa gráfica ¿Podría determinarse la influencia que genera en la población la "criminología mediática" y la reproducción del estereotipo del "delincuente"?

\section{Historizar para conocer}

Los medios de comunicación históricamente han cumplido un rol en la sociedad, sobre todo en lo que hace a la interpretación y construcción de la realidad (Berger y Luckman, 2018).

Y no es necesario el desarrollo de la tecnología para esto. En viejas épocas, donde no existía la imprenta: las "noticias" eran comunicadas por gaceteros y trovadores que se colocaban en un lugar visible y central de la comunidad y transmitían su "versión" de lo que acontecía (o la versión de quien le daba esa información). Si bien siempre se buscaba transmitir "La" verdad, "La verdad" no existe en sí misma, sino que siempre se accede a verdades subjetivas, que, como tales, son parciales y particulares, y no ajenas de ideología; además, esta "verdad" no es preexistente, sino que es un producto. Foucault (2010) se pregunta: “¿Cuál es el tipo de poder susceptible de producir discursos de verdad que, en una sociedad como la nuestra, están dotados de efectos tan poderosos?" (pág. 34).

Y dirá que la sociedad siempre está atravesada por múltiples juegos de poder, constituyen al cuerpo social. El ejercicio del poder requiere de la economía de los discursos de verdad "que funcionan en, a partir y a través de ese poder" (Ídem).

También se puede citar como ejemplo, en Latinoamérica, el uso que se ha hecho de los medios de comunicación al ponerlos al servicio del modelo del 
golpe militar, para impedir "la expansión de las acciones insurgentes de los pueblos latinoamericanos" (Schmucler, año, Pág. 4).

Existen ejemplos de transmisión ideológica por los medios de comunicación, de tinte más subliminal, como el que desentrañan Dorfman y Mattelart (1972) en Para leer al Pato Donald. Un análisis exhaustivo y agudo de cómo mediante una caricatura que parece "inocente", y dirigida a la primera infancia, se cuelan los ideales esperados por el "Tío Tom"xvi para la población.

En la actualidad, se cuenta con múltiples medios de comunicación, sobre todo gracias al avance y desarrollo tecnológico e informático, lo cual hace que no se paralice el país, como pasaba antes, cuando se emite un programa, porque se puede luego recuperar fácilmente en la web. Es decir, ya no hay "pérdida de información", más bien se asiste a un "exceso de información", lo que no quiere decir que ésta sea fidedigna en todos los casos. Cantidad no se equipara a calidad. Esto se debe a que, como plantea Foucault (2010), todas las sociedades necesitan y construyen verdades, y los medios de comunicación lo que hacen es reproducirlas, pero en esa reproducción también construyen realidad. El mismo autor, en "El orden del discurso" (2008) sostiene que la verdad se sitúa en el orden del discurso y que un discurso con poder es capaz de construir verdad.

Actualmente, la multiplicidad de medios y la velocidad con la que la información se transmite hace que no siempre se chequee ni la fuente ni la veracidad de la información, pero si la misma es transmitida por un medio reconocido y la sociedad considera que podría ser verdad, puede instituirse como tal. La pregunta fundamental sería ¿cómo deconstruir luego lo que se ha instalado como "verdad"?

Fiske (1987) explica que "el texto televisivo es un potencial de sentidos (...) los textos televisivos sirven como arena de lucha por el sentido" (pág. 11). 


\section{Conocer para comprender}

¿Existe un solo modo de comunicar? Es conocida la teoría de la comunicación humana que indica que existe un emisor, un mensaje y un receptor. También se hace necesario tener en cuenta que es una estructura que se sostiene y produce en la articulación de diferentes momentos encadenados, como son la producción, circulación, distribución, consumo, reproducción. Lo interesante está en que lo más importante son los roles en la comunicación, tanto la adjudicación como la asunción, porque para el ser humano, no es posible no comunicarse. Toda situación comunica, permanentemente.

La comunicación humana no puede equipararse a la que se produce entre dos artefactos. A la primera tenemos que pensarla como un proceso social y permanente que implica un conjunto múltiple de comportamientos. En esto, el contexto y la relación son fundamentales, como condicionantes.

Para la comunicación, se utilizan códigos que tienen sus reglas. Muchas veces éstas son explícitas y otras tantas, implícitas. Por esto es por lo que la comunicación humana no es lineal, sino que se la puede pensar más bien como circular, porque siempre hay un ida y vuelta, aunque sea involuntario: el sujeto puede ser consciente de lo que da, pero no siempre de lo que emana.

También queda deslindado que comunicar es dar información.

Florencia Saintout, en Los estudios socioculturales y la comunicación: un mapa desplazado (2011) sostiene que a partir de la década de los '80, la comunicación comienza a estar mucho más ligada con los procesos sociohistóricos y la construcción de sentido, en una articulación entre "comunicación, cultura y sociedad (...) se ubican en las transformaciones de la vida cotidiana, de los modos de sentir, de ver, de conocer, de congregarse". 


\section{Comprender para avanzar}

Pensar en la vertiente política de los medios de comunicación, lleva a plantear la perspectiva de la comunicación/cultura, que invita a poner el énfasis en lo comunicacional de la cultura en tanto producción de sentidos en la vida social (valores, experiencias, significados), incorporación de la cotidianidad (vida, muerte, religión, política, etc.).

Ya no puede pensarse el lugar del receptor del mensaje como pasivo, los sujetos no son tablas rasas, sino que están insertos en prácticas culturales que no pueden soslayarse. La sociedad capitalista tiene sus desigualdades y éstas se manifiestan.

Comunicación/cultura como inseparables: la comunicación produce cultura, la cultura produce comunicación y ambas producen ideología, por lo que no se pueden atender o estudiar ambos ámbitos por separado. Esto significa concebir a la comunicación como parte constitutiva de las prácticas sociales y no solamente como una cuestión técnica.

Se entiende por "cultura", a esa compleja malla de relaciones contextualizadas en que nos movemos, y que exige ciertos comportamientos para poder pertenecer, como sostiene González (2015):

(...) es lo que nos permite definir nuestra situación dentro de la vida social y colectiva. Es la herramienta privilegiada para conferirle un sentido a la realidad "real", tanto la que nos distingue porque nos ata con el grupo y la clase, como la que nos unifica porque nos funde en alguna de las múltiples formas de existencia de lo elementalmente humano (Diá-logos de la Comunicación $\mathrm{N}^{\circ}$ 26.).

Esta última definición, permite pensar que la cultura propone una visión que define al mundo. Debido a las desiguales posiciones que se encuentran en la estructura social, no deja de ser una "división práctica, efectiva y operante del mundo" (González, 2015). Estos movimientos no pueden no ser políticos, y van produciendo en la población que integra esta cultura, modificaciones 
subjetivas tanto individuales como colectivas. Van imprimiendo modos de ser, de actuar y de pensar, que configuran modos de relaciones sociales y vinculares, propios de cada momento socio histórico. Son construcciones de sentidos eficaces.

\section{Los medios de comunicación como productores de subjetividades}

Desde lo meramente comunicacional los medios en su comunicación/cultura, no sólo se sostienen en una reproducción, de "aparatos y estructuras" (Saintout, 2011), sino que también son productores de subjetividades.

Berger y Luckman (2008) abordan la temática de "la construcción social de la realidad" y describen la necesidad y la particularidad de la socialización primaria, la secundaria y la resocialización.

Por otro lado, Jacques Lacan (1949) plantea en "El estadio del espejo" que el ser humano llega a la vida "demasiado pronto" y postula el concepto de "prematuración" con el que sostiene que el ser humano nace antes de terminar de constituirse biológicamente; mientras el desarrollo de los animales se da en el estado fetal, el niño termina de desarrollarse una vez que se encuentra en el mundo exterior -externo al seno materno-. Es esto lo que hace que se necesite para la supervivencia en los primeros momentos de la vida del sostén, cuidado y fundamentalmente -esta es otra diferencia con los animales- afecto de otro, sólo con recibir alimento, no alcanza, sin el afecto, el cachorro humano muere.

Entonces, a diferencia de los animales, los seres humanos se encuentran socio-bio-psicológicamente determinados, ya que el sustrato biológico es necesario, pero no suficiente para la supervivencia. Abonan esta teoría las investigaciones realizadas por otro autor, René Spitz (1965), quien expone que el primer año de vida del infante humano es decisivo y determinante para el posterior desarrollo del sujeto. Para poder corroborar esta hipótesis, realiza un estudio en un orfanato en donde observa el diferencial trato que reciben 
algunos niños por parte de las nodrizas y los efectos que esto trae en su posterior desarrollo. Diferenció a los niños que sólo recibían el alimento en el horario pautado por la institución de los que eran alimentados en medio de cantos, caricias y en un clima afectuoso. Los niños del primer grupo, en su mayoría fallecieron antes del primer mes de vida, los que sobrevivieron acarrearon graves consecuencias neurológicas, cognitivas y de desarrollo, muchos de ellos desarrollaron autismo severo.

Con este estudio, Spitz comprobó que el ser humano no sólo necesita del alimento, sino también de los cuidados que ello conlleva: el cariño, el afecto y la protección por parte de la madre o del agente que lleve a cabo esa función.

El ser humano es, pues, un ser social, construido por -a la vez que constructor de- lo social, enmarcado en un contexto sociohistórico que lo delimita y determina y del cual también es productor.

En estos últimos años, como efecto de los cambios sociales y culturales, las modificaciones en los tiempos individuales, el desarrollo de las profesiones y las especializaciones, la búsqueda del exitismo cuyo empuje privilegiado es la necesidad de tener para ser; la familia o grupo de crianza ha delegado gran parte del tiempo destinado a la socialización primaria a los medios de comunicación. Es decir, una parte importante del día los niños se encuentran frente a la televisión, en la computadora o utilizando algún tipo de dispositivo electrónico.

Mar de Foncuberta (2006) sostiene que se pueden analizar cuatro aspectos referidos a las funciones que cumplen en la actualidad los medios masivos de comunicación en las sociedades: la dimensión socializadora, como espacio de ejercicio de la ciudadanía, como agente educativo (en tanto selección de los contenidos que se van a transmitir y difundir), y tiene un protagonismo importante en la gestión del ocio de las personas (en esto juega un papel sustancial la programación y los horarios en los que se ubican ciertos programas en la grilla, qué tipo de series y ficciones son las que acompañan, por ejemplo, los momentos de las comidas). 
Un concepto que no se debe desatender, es el de "hegemonía". La lucha cultural constituye la lucha por la hegemonía. Es por esto por lo que se considera a la comunicación ligada con el poder. Los medios de comunicación buscarán reproducir el statu quo hegemónico, generando un consentimiento aparentemente voluntario de las clases menos favorecidas, las minorías, para el sistema que lo que hará es seguir sosteniendo esa subordinación.

En este sentido, la "verdad", que es del orden del discurso, y teniendo en cuenta que el poder tiene el poder de construir verdades, siempre debe comprenderse desde el punto de vista a cómo está construida y, sobre todo, dilucidar para quién y en qué momento histórico social determinado. Porque, en definitiva, si a algo se ha arribado con este recorrido, es a que la subjetividad -social o singular- no es el producto absoluto de la verdad, sino de la cultura, de la historia y de la sociedad, no se la puede comprender sin abordar el contexto de surgimiento.

Las normas sociales, que regulan los vínculos y los lazos en la sociedad, lo que se constituye como lo "socialmente aceptable" -normas, pautas culturales-, no son nunca ni neutrales ni objetivas, sino que tienen como origen los intereses de quienes ejercen el poder social, y que sólo buscarán mantener esos espacios de poder; el modo de hacerlo será mediante la neutralización, con su incorporación al sentido común compartido. En esto, los medios de comunicación, con su función reproductora, tienen un papel fundamental.

En la criminología mediática, puede verse con frecuencia cómo se va implantando en la subjetividad de la población el enfrentamiento con el semejante vulnerable, al que los medios han etiquetado como el potencial peligroso, naturalizando sus muertes, mostrando la "inseguridad" y ocultando los casos de "gatillo fácil", las muertes sin proceso, en "enfrentamientos", muertes justificadas en la lucha contra la delincuencia.

El juez Eugenio Zaffaroni (1990) plantea en "En busca de las penas perdidas", que los medios de comunicación masiva son usinas ideológicas del estado y segmentos del sistema penal. 
En ese texto da un ejemplo muy característico respecto a las series de televisión y la ideología implícitas en ellas y cómo esto entra en los hogares casi "inocentemente": cita a la serie "Miami Vice" donde el sujeto de color y el latinoamericano son siempre narcotraficantes, delincuentes, a los que el blanco-bueno-norteamericano debe combatir, apresar, matar, para salvar a la sociedad de la maldad.

En "La cuestión criminal" dedica varios apartados a trabajar lo que ha formalizado bajo la nominación de "criminología mediática" - que se desarrolla en un apartado de este trabajo-, donde despliega sus teorizaciones respecto a la incidencia de los medios masivos de comunicación en la conformación y difusión del estereotipo de criminal y sostiene que los sujetos con los que las personas se cruzan habitualmente por las calles y en el trabajo, tienen la visión de lo criminal y de los criminales que construyen, producen y difunden los medios.

Hace hincapié en diferenciar lo que es el "discurso" de los medios, del "mensaje". Dado que la televisión es la que mayormente se encarga de esta selección de una porción de la población que porta el estereotipo del criminalizado, se debe hablar de "mensaje", dado que lo que se difunden son imágenes, con todo el poder que tienen (no es lo mismo la descripción oral que se pueda hacer desde un discurso y que requiere de la imaginación del sujeto que lo oye para armar esa imagen y construir el estereotipo, que verla e identificarla en el cotidiano, en este segundo caso, no se requiere mayor esfuerzo por parte de quien recibe esas imágenes, es lo que Bourdieu (1997) planteaba respecto a que la televisión es lo opuesto a la capacidad de pensar). La imagen nos refiere necesariamente a una cosa concreta, de ahí el valor de lo visual, la repetición de una noticia y al mismo tiempo por detrás la repetición de las imágenes que acompañan a ese informe.

Noam Chomsky xvii sostiene que fomentar que la población no piense, no reflexione, es una de las estrategias fundamentales de manipulación que llevan a cabo los medios de comunicación. Para poder cumplir con ese objetivo, se producen contenidos de entretenimiento y distracción para mantener al público 
ocupado y no darle tiempo para el pensamiento. La televisión es quien produce la mayor cantidad de distractores.

Lo que se hace con la imagen y la información que se tiene del hecho, es una construcción: se construye la noticia y se utiliza la imagen como soporte. Mar de Foncuberta (2006) sostiene que vivimos en sociedades cada vez más complejas y fragmentadas que no pueden vivir al margen de la imagen, estamos rodeados de ellas, se imprimen en nuestras retinas y nos acompañan todo el día. Este tipo de producciones apelan a la emocionalidad del receptor, para tener mayor llegada y repercusión lo cual constituye otra de las modalidades de manipulación mediática. Dice Chomsky:

Hacer uso del aspecto emocional es una técnica clásica para causar un cortocircuito en el análisis racional, y finalmente al sentido crítico de los individuos. Por otra parte, la utilización del registro emocional permite abrir la puerta de acceso al inconsciente para implantar o injertar ideas, deseos, miedos y temores, compulsiones, o inducir comportamientos (pág. 2, op. Cit.).

Es así como podemos decir que la "criminología mediática" lo que hace es crear una realidad -una entre muchas posibles- y presentarla como "la" realidad, donde aparecen enfrentadas las "personas decentes" con el grupo de "criminales" los cuales son identificados por el estereotipo que permite sostener esa distinción.

Para que esta diferenciación perdure en el tiempo y resulte creíble, no queda otra opción más que "inflar" las características negativas de quien porta el estereotipo sobre la base del peligrosismo y es allí donde el concepto de peligro se une al de seguridad, reduciendo a la inseguridad solamente a situaciones que tienen que ver con la violencia del robo.

Este modo de vender las noticias sobre la "inseguridad" y de introducirse en los hogares, es la condición de posibilidad de la justificación del sentido común de las ejecuciones sin proceso, de los muertos por gatillo fácil, de los 
"linchamientos". Esto ocurre porque, como plantea Foucault (2008) en El orden del discurso, en toda sociedad el discurso está seleccionado, controlado y redistribuido; se hace necesaria la construcción de un discurso con rituales, normas y consecuencias, esto es lo que configura poderes.

Feinmann (2018) dirá "lo que tiene que hacer el poder comunicacional es crear la paranoia en la población"xviii, sostiene que, en la actualidad, los medios de comunicación "bombardean" a la población con noticias, con información que es producida por ciertos sectores del poder, con la única función de mantener el sometimiento de las clases subalternas. El poder, al tener el poder de lo comunicacional, difunde sobre la población un discurso y un pensamiento que expresa los intereses de la clase dominante: se difunde lo que esos sectores quieren o necesitan que el resto de la población piense, para que actúe en consecuencia, siendo funcionales a la reproducción de un statu quo. El modo en el que esto se lleva a cabo es mediante la producción y reproducción de un "sentido común" que tiene la particularidad de ser el pensamiento del poder.

Feinmann (2008) afirma que es una modalidad que lo que permite es sujetar al sujeto (retomando las conceptualizaciones de Foucault al respecto): la población termina pensado lo que el poder quiere que piense, perdiendo la libertad y la autonomía, favorecido por la masividad de los medios que constantemente reproducen el discurso armado del sentido común para idiotizar al receptor. La televisión e internet se "venden" como entretenimientos, sin permitir que se perciba su intención latente, que es la del control social de la población.

El sentido común lo que produce es que todas las personas piensen igual sobre los temas esenciales de una sociedad, estableciendo una disputa entre el pensamiento autónomo de los sujetos y el pensamiento del poder. El poder mediático triunfa cuando logra imponer el sentido común como pensamiento de todos. Los medios difunden e imponen una ideología determinada, neoliberal, que es la ideología económica del occidente capitalista. Por esto debe cuidarse el orden, quedando el mercado en manos de los monopolios, buscando el 
control de la sociedad civil, y se hace mediante la imposición de una paranoia sobre la población: con la sensación de inseguridad, reforzada por la creación y reproducción del estereotipo del delincuente.

El estereotipo no sólo tiene que ver con aquellas características físicas que un sujeto porta y que lo hace susceptible de ser captado por el sistema penal en tanto asunción de un rol previamente asignado, sino que se sostiene en una premisa biologicista, dado que mientras porte el estereotipo -a lo largo de toda la vida si no cambia el chivo emisario de la sociedad- el sujeto seguirá siendo peligroso, por lo que cualquier intento de respeto de sus garantías procesales será tomado por la sociedad como una aberración de la justicia que falla en detrimento de la "sociedad" -porque quienes portan el estereotipo no son considerados "gente como uno", sino que son excluidos y marginados-.

A quienes portan el estereotipo, hay que dejarlos siempre encerrados, y por el mayor tiempo posible, porque son incorregibles.

Ahora bien, ¿qué pasa con todos aquellos otros delitos que no son objeto de mayor atención por parte de los medios de comunicación y que sin embargo afectan a una porción más grande de la sociedad y por un tiempo más prolongado? La referencia es en este caso a los delitos de cuello blanco, estafas, desfalcos.

Es por esta construcción que realizan los medios de comunicación, que se caracteriza por la deformación de la realidad, en donde se enfrentan dos bandos, los buenos y los malos, que se llega a la certeza de que el único modo de hacer algo con los conflictos tiene que ver con la punición y la violencia. Esta construcción es posible en tanto pensemos a los medios como mediadores, como actores políticos, sociales, culturales y económicos.

Si se analiza críticamente la programación que en la actualidad se presenta en la televisión, en la que lo que priman son los noticieros y dentro de ellos lo que se llaman las "noticias rojas", de policiales, puede afirmarse que las personas están sobreexpuestas a un discurso peligrosista, que lo que hace es apuntar al miedo. 
Los medios son actores activos de transformaciones sociales, toman una porción parcializada de la realidad y generan verdades a partir de sus propios intereses ideológicos $\mathrm{y}$, de este modo, construyen percepciones en la sociedad. Se trata de la construcción, selección y jerarquización de la información en tanto los medios son quienes legitiman la palabra de unos por sobre la de otros, se selecciona qué se difunde y qué se oculta es una decisión subjetiva, y se hace en forma intencional.

Todo medio posee una intencionalidad editorial guiada por una ideología que se puede rastrear si se presta atención al tratamiento que se realiza de las diferentes noticias y temáticas. En los diarios es importante poder visualizar la estructura que da soporte a la publicación, y luego analizar el contenido: qué se dice y cómo.

En lo que tiene que ver con lo estructural, el medio propone una jerarquización de la información que se hace visible en la selección no sólo del tema que será, por ejemplo, nota de tapa, sino en cómo se publica: ubicación en la hoja, con o sin foto -a color o en blanco y negro-, tamaño asignado -toda la hoja, media hoja, un cuarto-, tamaño y color de la letra del título, cómo se titula y qué información se coloca en el título, en la volanta y en la bajada, actores que se seleccionan para que sean los que relaten la noticia. Ninguno de estos elementos mencionados es elegido al azar, sino que tienen una intencionalidad fomentada por un lado por la posición político-ideológica del medio y, por otro lado, por la respuesta que se espera generar en el lector. La selección, jerarquización e intencionalidad editorial, que forman parte de la construcción de una noticia, constituyen decisiones políticas del medio.

Concomitantemente con la reproducción de noticias que apuntan a aterrar a la población, aparece la construcción del estereotipo de quien es el "encargado" de sembrar el miedo, es decir, el estereotipo del "delincuente". Este "enemigo interno", no puede dejar de ser nombrado, descripto, etiquetado, porque es de quien hay que cuidarse, a quien hay que temer y denunciar. 
Como correlato, se puede también situar que aparece otro estereotipo, que es igualmente desubjetivante, y que tiene que ver con la víctima. La persona que ha sufrido un ilícito aparece una y otra vez en los medios contando la situación que le ha tocado atravesar, fijando a ese sujeto en su posición de víctima que lo único que puede hacer es exigir justicia, que muchas veces no tiene que ver con lo que se encuentra tipificado en el código, sino que se pide una retribución que se sabe de antemano que no es posible, dado que los castigos, penas o condenas nunca son equitativas con el daño sufrido.

Esta "víctima" de delito que presta su imagen y su discurso a los medios en la construcción de esa noticia, puede generar $-y$ habitualmente lo haceempatía en quien se encuentra mirando la televisión, una identificación que lo que hace es perpetuar el estereotipo del "delincuente". Una vez pasado el tiempo en que esa noticia es "vendible y rentable", la víctima es olvidada por los medios que antes la convocaban, dejándola sola con su padecimiento.

El "paseo" de las víctimas por los medios de comunicación genera el efecto de "onda expansiva" que en tiempos eleccionarios se traduce en propuestas, por parte de los políticos, de mayor seguridad, de lucha contra la inseguridad. Una y otra vez puede verse repetirse ese mismo circuito. De este modo, se puede sostener que el poder punitivo realiza su selección de acuerdo con los reclamos de la criminología mediática.

Lo cierto es que por más que se presenten junto con la víctima todo un plantel de expertos para dar su opinión profesional sobre el caso, se le dediquen más minutos en televisión y más centímetros cuadrados en los diarios -o una primera plana-, nada de lo que se presenta en los medios de comunicación en relación con lo criminal tiene que ver con la frecuencia real de ese tipo de violencia.

Todas las sociedades, históricamente, se han creado un estereotipo de "delincuente". En la actualidad, es el del joven o menor de edad, de barrios carenciados, con ciertos rasgos físicos que se exacerban en la transmisión de la imagen como por ejemplo ser morocho, cierto modo de vestir, como el usar 
viseras, piercings, tatuajes, camperas holgadas. De este modo, se termina homologando pobreza con peligrosidad.

Lo interesante es que, quien porta este estereotipo, que es reproducido por los medios de comunicación, difícilmente si va a buscar un empleo, lo consiga, no podría asegurarse siquiera el que le abran la puerta de un local.

Se entra así en un circuito que se puede describir de la siguiente manera: un sujeto porta el estereotipo, no le dan trabajo por esa portación -no por sus condiciones aptas o no aptas para desempeñarse en esa tarea-, se frustra una y otra vez en esa búsqueda, necesita el trabajo para poder vivir, no lo consigue, tiene mayores posibilidades de delinquir para conseguir los medios de subsistencia. Vemos, de este modo, cómo la exclusión de ese sujeto de lo social lo empuja a cumplir con un rol previamente impuesto para el estereotipo. Es el caso de la profecía autocumplida que lleva a los medios de comunicación a confirmar su hipótesis del peligrosismo y continuar con la reproducción.

Al mismo tiempo, la sociedad comienza a solicitar penas más duras, baja en la edad de imputabilidad, ejerciendo presión que, en ocasiones, termina modificando las legislaciones -recordemos la Ley Blumberg-. Es por esto por lo que los medios de comunicación pueden considerarse segmentos del sistema penal, porque luego con esas leyes todos somos regulados, además de que ese "empuje" a la asunción de un rol previamente establecido y reproducido por los medios de comunicación es lo que hace al sujeto susceptible de ser captado por el sistema penal, es lo que R. Zaffaroni (1998) llama la "vulnerabilidad socio-penal".

Nada dicen los medios respecto a que dentro de la "seguridad" debe encontrarse comprendido no sólo el no ser víctima de delitos contra la propiedad, la integridad física y la vida, sino también el completo acceso a derechos que posibilite una situación de equidad.

Es interesante, entonces, pensar cómo se puede hacer para deconstruir esos estereotipos e ideologías que los medios reproducen en forma acrítica. Un modo posible de desandar esos prejuicios instalados socialmente, tal vez 
tengan que ver con el concepto de contracultura. Según R. Williams (2009), cada cultura produce su propia contracultura, y la limita dado que es una posición crítica a la hegemonía, que busca comprender para avanzar, no enquistarse en posiciones ideológicas inmodificables.

\section{Sobre la necesidad del contra discurso}

Estas grandes usinas Ideológicas, que están cada vez más arraigadas en el cotidiano, digitan gran parte del tiempo y conforman la realidad, los imaginarios, allí radica su poder. Unos párrafos más arriba, se planteaba que los niños pasan gran parte de su tiempo en contacto con estos medios y se encuentran en etapa de conformación de su psiquismo y de su subjetividad: ¿Cómo hacer luego para deconstruir esos imaginarios que se han moldeado en etapas tan tempranas? ¿Cómo revertir los efectos en la subjetividad de la población y, sobre todo, de ciertos sectores que han sido seleccionados por los medios de comunicación como los futuros criminalizados?

Tomando lo que plantea Foucault (2008) de la compleja malla en donde un pequeño cambio en un extremo genera un movimiento en toda la trama, puede pensarse que para generar una modificación que llegue hasta todos los extremos de la estructura, se hace necesario que el cambio sea lo suficientemente fuerte. De lo contrario, la modificación no será ni total ni duradera.

¿Alcanza con apagar el televisor, no usar la computadora, no conectarse a internet? Claramente no, porque con ese acto lo que se consigue es dejar de mirar, pero la ideología sigue transmitiéndose y reproduciéndose mientras haya un aparato encendido. En este punto, es interesante el planteo de Julian Assang $\mathrm{e}^{\mathrm{xix}}$, quien sostiene que es en los medios mismos donde debe librarse la batalla.

Mar de Foncuberta (2006) sostiene que el lector-televidente actual ya no confía tanto en lo que dicen los medios, y esto puede ser un aliciente posible del cambio. 
El modo privilegiado para poder generar y sostener un contra discurso en materia de criminología, tiene que ver con fortalecer al Estado. En esto será primordial fomentar lazos sociales que sean más estables, que tiendan a la inclusión y que permita la desestigmatización del diferente, del pobre, del marginado. El otro no es más que un semejante vulnerable.

Si el Estado y la población como parte integrante, lograran tomar conciencia de la corresponsabilidad implícita en el haber dejado avanzar el proceso de vulnerabilidad de los sujetos de sectores marginales y comprendieran que la seguridad también tiene que ver con tener el mayor acceso posible a los derechos, sería más sencillo poder vislumbrar que el otro no es mi enemigo, sino un semejante que no ha tenido las mismas posibilidades. La estigmatización, la exclusión que ésta conlleva y el castigo violento no se aproximan en lo más mínimo a una solución de la criminalidad, sino que más bien pareciera ocurrir todo lo contrario. 


\section{LAS CORRIENTES CRIMINOLÓGICAS Y LA NOCIÓN DE CASTIGO}

Palabras clave: Criminología, positivista, mediática, Derechos Humanos

Es mucho lo que se ha escrito, discutido y debatido respecto de la Criminología: acerca de si es una ciencia en sí misma o si es una disciplina auxiliar de otras disciplinas científicas; si es posible pensar una Criminología en relación y vinculada con los Derechos Humanos (generalmente disociados); entre otras discrepancias. También existe controversia respecto a su época de surgimiento, si nace en el siglo XIX con el Positivismo o en el siglo XVIII con la "Escuela Clásica".

La Criminología, según López Rey, como ciencia empírica

(...) ha de entenderse como la disciplina sociopolítica cuya finalidad esencial es la formulación de una política criminal que permita lo más efectivamente posible la prevención y control de la criminalidad conforme a las exigencias de libertad, dignidad, igualdad, seguridad individual y colectiva, entendida como esenciales del desarrollo nacional e internacional (Ruano y Ortiz, J. (2012)).

Es decir, no se reduce solamente al estudio del crimen, sino que se ocupa, además, de todo lo que implica subsidiariamente. En este sentido, debe ser diferenciada del Derecho Penal, que se ocupa de la ley y del delito, y de la criminalística, encargada de las investigaciones inmediatamente posteriores a la comisión de un hecho delictivo.

Como postula Lola Aniyar de Castro (1981), la Criminología pretende poder responder a las preguntas “¿Quién? ¿Cómo? ¿Cuánta? (quién es el delincuente, cómo se realiza el delito, cuánta delincuencia existe)" (p.5).

Se tomará, en esta ocasión, a la Escuela Clásica como punto de arranque de la Criminología, no obstante, ésta haya existido siempre, aunque sin una formalización que diera cuenta de ella como tal. Sólo como un ejemplo, basta leer "Utopía" de Tomás Moro, escrito en 1516, donde si bien no habla de una 
"Criminología", deja planteado cómo cada sociedad produce los delincuentes que necesita y que se merece y el tratamiento que hace de ellos:

\begin{abstract}
El aumento del coste de vida trae consigo el que la mayoría de los hacendados despidan a gran parte de sus servidores, y éstos, ¿qué otra solución tienen sino pedir limosna o bien robar, cosa que admiten buenamente muchos nobles? (...) Permitís que se eduque tan deficientemente a los niños y que sus costumbres se corrompan desde pequeños, pero después los condenáis, al llegar a hombres, por faltas que en su niñez ya eran previsibles. ¿Qué otra cosa es esto más que hacerles ladrones y condenarlos después? (p. 47).
\end{abstract}

Raúl Zaffaroni (2008) también plantea esta existencia de la Criminología como conocimiento acerca del mal desde el momento mismo en que nace el poder punitivo, es decir que lo sitúa desde el surgimiento de los demonólogos como primeros criminólogos. Pero es de la mano de los psiquiatras -con la corriente positivista- que adquiere la categoría de saber académico.

\title{
Las corrientes criminológicas y la noción clásica de castigo
}

En una progresión histórica, puede caracterizarse a la Criminología en tres grandes corrientes: clásica o precientífica (siglos XVII-XVIII), positivista o científica (fines del siglo XIX) y crítica (a partir de 1979-80). Si bien pueden situarse estos tres tiempos, superadores uno del otro, es posible aún hoy encontrar modelos criminológicos en funcionamiento que toman elementos de uno o de otro, en forma simultánea e indistinta, con relación a cómo se dan los juegos de poder.

M. Foucault (1975) en "Vigilar y Castigar", realiza un recorrido por distintos momentos en relación con los crímenes -y desviaciones que alteran el orden social- y su castigo desde el Derecho Monárquico (siglo XVII) hasta el advenimiento del Sistema Penal (siglos XIX-XX), en un pasaje por los juristas reformadores (siglo XVIII). 


\section{Criminología Clásica}

La primera corriente criminológica, la denominada "Escuela Clásica" (siglos XVII-XVIII), nace hacia el Medioevo, con los nuevos modos de producción y las nuevas clases sociales, como la burguesía. En este tiempo, lo que permitía fundar un juicio estaba marcado por tres condiciones: el conocimiento de la infracción, el conocimiento del responsable y el conocimiento de la ley (Foucault, 2008). Son los momentos previos a la Revolución Francesa, cuyo advenimiento produjo grandes modificaciones a nivel económico y social.

En sí misma, y desde una postura crítica, la Escuela Clásica no puede considerarse como una escuela criminológica en su sentido más estricto, porque sólo se ocupa de lo que el Estado hace con el delito, y deja por fuera los otros objetivos de la criminología -el estudio del crimen, de la persona del infractor y de la víctima-. En este punto es posible realizar una relación con el primer momento que sitúa Foucault, donde deja plasmado que, en el Derecho Monárquico, tiene una gran importancia la figura del rey, y ¿qué es lo que se hacía con el delito? -lo único a lo que se abocaba la Criminología Clásica-: se lo castigaba mediante el suplicio, la tortura, que se ponía en correlación con la intensidad del delito, falta o infracción cometida. Existía, entonces, una función jurídico-política, que era restaurar la soberanía del rey que había sido ultrajada, $y$ es por eso por lo que el suplicio estaba reglado. Se instauraba como una venganza del soberano hacia quien cometía el delito. Se lo entendía, entonces, como un ritual político, una manifestación de poder, un modo de reactivar el poder y no de restablecimiento de la justicia. El cuerpo se constituía como la sede de la verdad y el castigo.

El mecanismo de producción de verdad era por medio del suplicio, lo que establecía un castigo anticipado de esa confesión que luego se producía. Por medio del suplicio, lo que se interroga, es el cuerpo, que se constituye como el lugar de obtención de la verdad (Foucault, 2008, p.53). Esto produce varios efectos; en principio, el sujeto considerado culpable, se convierte en un "pregonero de su propia condena" (Foucault, 2008, p. 53), en cuanto se torna 
público tanto el crimen cometido como la imposición de justicia que implica un castigo que se porta en el cuerpo. En segundo lugar, permite que se siga con la reproducción de la "escena de la confesión" (Foucault, 2008, p. 53), aunque forzada y con una retracción pública -es esto lo que instaura al suplicio como momento de verdad-. En tercer lugar, anudar el suplicio al crimen, establecer una correlación entre ellos: este cuerpo que se ve supliciado, está así a consecuencia del crimen cometido. En cuarto lugar, como prueba última, los gritos del condenado ante la lentitud del suplicio, la exposición del sufrimiento.

Los ciudadanos, el pueblo, quienes concurrían a la plaza pública a observar los suplicios, eran víctimas del crimen, pero también testigos y cómplices del castigo.

Según lo describe Foucault (2008), el objeto de la Criminología, es el crimen entendido como una patología social que en todo tiempo y lugar debe ser combatida y extirpada a través de la etiología y la terapéutica; cuando se ven afectados los valores esenciales el espacio que se ve lesionado se termina convirtiendo en algo de orden público $\mathrm{y}$, de este modo potencial de criminalización, esto quiere decir, de su conversión en delito o falta y, por lo tanto, es objeto de represión, resocialización o tratamiento. La Criminología Clásica racionalizó el control a través de la legislación.

Con el surgimiento de la teoría general del contrato, en la época de la Revolución Francesa, aparecen los juristas reformadores y el Código Penal. A partir de este momento, el delito y la pena empiezan a estar en relación, y el castigo ya no es sobre el cuerpo, sino que se constituye como una representación. El castigo pasa a ser una suspensión de derechos, y, en algunos casos, se indican trabajos comunitarios. Se opera más bien sobre el alma de los sujetos por medio de signos y representaciones, lo que constituye un castigo simbólico que se produce a partir de la codificación del libro. A quien se castiga es a un infractor, alguien que cometió una falta contraria a los códigos. 


\section{Escuela Positivista}

La Corriente Positivista corresponde a una ideología de pensamiento que surge en Italia hacia fines del siglo XIX y comienzos del XX, que tenía por objetivo poner un freno a ciertas formas de infracción, como, por ejemplo, los bandidos rurales. Así, hacia fines del siglo XVII puede notarse una diferencia en el tipo de delitos que se cometen: ya no se dan tanto los asesinatos a sangre fría, sino que empiezan a aumentar los delitos contra la propiedad, robos, estafas. Es el momento de la inclusión e influencia de las ciencias en el derecho en general y en el Sistema Penal.

Raúl Zaffaroni (2008) hace referencia al modo en que la ciencia, específicamente la psiquiatría, viene a contribuir en la construcción de una Criminología que se torna racista, reaccionaria y legitimante de la destrucción de las garantías penales, hasta el punto de legitimar y justificar el genocidio del diferente -por ejemplo, con el nazismo-.

El máximo exponente de la Escuela Positivista -y quien marcó el inicio de la Criminología como ciencia- fue Cesare Lombroso, miembro de la Scuola Positiva italiana, aunque el término "Criminología" se le atribuye a Raffaele Garófalo -quien formaba parte de la misma escuela- que amplió la concepción de Lombroso al introducir los factores psicológicos: entendía el delito como un "hecho natural".

Luego Enrico Ferri sumaría los factores del carácter sociológico. Dentro de este modelo -que es el de la ciencia-, lo que toma predominancia a la hora de determinar al crimen, los criminales y su pena, tiene que ver principalmente con lo biológico, el determinismo, lo heredado -criminales "natos"-. El crimen es entendido como una enfermedad dentro de lo social, y el criminal como un enfermo, por lo que se pierde el estatuto de conflicto y son enviados al olvido tanto el victimario como la víctima, esta última, además, tenía prohibido interferir en la defensa que proponía el Estado. Los hechos de la naturaleza estarían subordinados a leyes naturales inmutables, por lo tanto, esos factores 
debían ser eliminados: se busca una explicación "científica" de la criminalidad, una "causalidad".

Se presenta una disociación entre la persona y el delito ya que, al basarse en las condiciones físicas de una persona para la determinación de la peligrosidad, se puede ser peligroso sin delito, imponiéndose penas a todos aquellos que resulten molestos, generalmente quienes integraban la marginalidad de las ciudades. Pero no sólo los excluidos de la sociedad eran peligrosos, sino también los genios, de quienes había que cuidarse y desconfiar. De este modo, al dejar las causas del delito en lo biológico, las sociedades podían descansar tranquilas al saber dónde estaba la "maldad", lo que les permitía aislarla en instituciones.

La cárcel se convierte en laboratorio de criminología, pero obviando la influencia del sistema penal en el sujeto.

En relación con el modo de castigo que se utilizaba en el momento del positivismo, desde la segunda mitad del siglo XVIII, empezaron a darse las protestas contra los suplicios que comienzan a aparecer como algo intolerable, algo que irrita. Surge la necesidad de cambiar el modo de castigar. Pero no es el respeto por la humanidad lo que guía esta modificación, sino una justicia más sutil: la idea no es castigar menos, sino mejor, lo que introduce un poder que se entierra en forma más profunda en el cuerpo social, un modo de administrar los ilegalismos. Sostiene Foucault (2008):

La reforma del derecho criminal debe ser leída como una estrategia para el reacondicionamiento del poder de castigar, siguiendo modalidades que lo vuelvan más regular, más eficaz, más constante y mejor detallado en sus efectos; en suma, que aumente estos efectos disminuyendo su costo económico y su costo político (p. 93 y sig.).

Las causas de la reforma penal del siglo XVIII son, entonces, "constituir una nueva economía y una nueva tecnología del poder de castigar" (Foucault, 2008, p. 103). Son los sujetos quienes consienten en el pacto social, aceptando 
las leyes, y quienes luego quebrantan ese orden establecido, ese contrato, lo que los convierte en enemigos de la sociedad, la que está habilitada para castigarlos. Es decir, los delitos, atacan a toda la sociedad, no sólo al damnificado directo, y es toda la sociedad la que participa del castigo. Por lo tanto, lo que antes era un castigo para el restablecimiento de la soberanía del rey, es ahora por la defensa de la sociedad.

A comienzos del siglo XIX desaparece el "gran espectáculo" de la pena física, del cuerpo supliciado, se empieza a dar lo que Foucault (2008) llama la era de la "sobriedad punitiva" (p. 24): lo que comienza a tomar fuerza como castigo es la imposición de la pérdida de algún bien o derecho, aunque se conserva un fondo supliciante, pero disfrazado por una penalidad que ya no es la del castigo físico corporal, sino que lo que se castiga, es el alma. También entre los siglos XIX y XX aparece en su esplendor la disciplina, un tipo de poder para normalizar a los individuos, pero no es una institución.

Es el momento del Sistema Penal, donde el poder no reprime, sino que se utilizan maneras sutiles de normalizar al desviado. Lo fundamental de las penas es que no sean definitivas, sino que den ocasión a la modificación, a la transformación por medio de la pena. Hay tres mecanismos esenciales para un "buen encauzamiento", que son instrumentos simples, que realizan todo un trabajo sobre el espacio, donde todo movimiento está codificado

1-Vigilancia jerárquica: que consiste en controlar mediante un dispositivo de coacción, el panoptismo.

2-Sanción normalizadora: incluye la infra-penalidad y la microfísica del poder.

3-Examen: combina las dos anteriores. Es la unión entre poder y saber.

Esto se visualiza en la cárcel, que es un aparato de saber donde se busca un sujeto obediente, se realiza un proceso sobre el cuerpo y sobre el alma, una modificación de los espíritus: la institucionalización del poder de castigar. 
Es durante la última mitad del siglo XVIII y la primera del siglo XIX donde se encuentra el origen de la forma contemporánea de la generalización de la privación de la libertad como pena (que fue un producto más de la Revolución Industrial, como modo de disciplinar, al estilo del entrenamiento fabril, aunque se puede dudar de la verdadera eficacia de la prisión como disciplinante).

Pero la cárcel, o el encierro, como modo de penar a los delincuentes, es criticada por los reformadores, en tanto se presenta como incapaz de responder en forma adecuada a la especificidad de los delitos. Dice Foucault (2008):

Carece de efectos sobre el público. Porque es inútil a la sociedad, perjudicial, incluso: es costoso, mantiene a los condenados en la ociosidad, multiplica sus vicios. Porque el cumplimiento de tal pena es difícil de controlar y se corre el peligro de exponer a los detenidos a la arbitrariedad de sus guardianes. (P. 133)

Es la institución cárcel la que, en definitiva, construye al delincuente. Éste, es un sujeto con biografía, y de ella se desprende el hecho. De este modo, lo que se sanciona no es el delito sino el modo de vida que atenta contra los parámetros de salud de una sociedad. No se castiga al sujeto por lo que hizo sino por lo que es, estaría sobredeterminado por su biografía.

El funcionalismo introduce una ruptura con el Positivismo, y pone el acento en la conducta delictiva o criminal propiamente, desde el punto de vista estrictamente social, factor dinámico y no estático, por lo que su concepto central es el de desviación: desviación a una norma social.

El mayor aporte del funcionalismo es la teoría de la anomia -expresión tomada de Durkheim y que retoma y desarrolla Merton-, la cual consiste en interpretar la desobediencia a las reglas sociales como una contradicción entre estructura social y cultura, a partir de la cual se puede confeccionar, luego, la tipología de las conductas desviadas: el conformismo, el ritualismo, el retraimiento, la innovación, la rebelión. En este caso el tipo de tratamiento o 
pena sería mediante la terapia, la medicalización, el aprendizaje y la disciplina, entrecruzadas y autoinfluenciadas durante la condena de privación de libertad.

\section{Corriente crítica}

Desde la década de 1960, la criminología realiza una torsión -ya que deja de estar el saber en la psiquiatría para pasar a los sociólogos- que va del paradigma etiológico al de la reacción social, lo que implica una ampliación del campo de estudio en donde se pasa a tener en cuenta la violencia y el efecto reproductor implícito en el poder punitivo y en el sistema penal. Se pone en cuestión la legitimidad con la que actúa el sistema penal y el dogmatismo con el cual opera.

La corriente crítica toma en cuenta una visión mucho más amplia y compleja del acto delictivo ya que ésta implica tener presente la concepción dinámica y contextualizada de las personas que intervienen en la situación conflictiva, como sujetos activos e interactuantes. Se contempla no sólo el aspecto biológico -el cual es desestimado como factor determinante- sino también lo que tiene que ver con lo específicamente humano: el conflicto y los costos que acarrea tanto a nivel personal como social la comisión de un acto. Los objetivos consisten en resocializar al delincuente, reparar el daño y prevenir el crimen.

Los criminólogos de esta corriente se remiten a una comprensión crítica de la sociedad, se tiene en cuenta que las diferencias de clases y las situaciones socioeconómicas y de explotación social generan los alejamientos de la norma y es sólo mediante la explicación de esas condiciones que puede entenderse lo que estas desviaciones implican o significan en cada uno de los casos en particular. Los factores ambientales ejercen una influencia que puede llegar a considerarse más o menos significativa sobre algún elemento fundamental de la naturaleza humana. 
De este modo, lo que podría considerarse como una nueva Criminología, no lo es tanto, dado que ya Marx y otros teóricos sociales clásicos se preocuparon por estas mismas cuestiones.

Como postulan Taylor, Walton y Yang (1997), "lo imperioso es crear una sociedad en la que la realidad de la diversidad humana sea personal, orgánico o social, no esté sometida al poder de criminalizar" (p. 298).

Zaffaroni (1988) sostiene la necesidad poder pensar(nos) desde el propio margen, y dice:

La estructura del poder mundial se presenta como un centro y una periferia, pero la periferia abarca una cantidad de parajes marginales. Nuestra aproximación sólo será desde uno de esos márgenes y, por consiguiente, también será parcial pues hay otros márgenes, respecto de los cuales sabemos muy poco (p. 3).

Es decir, no se puede extrapolar un modelo criminológico de un lugar a otro, de una sociedad a otra; si bien pueden plantearse determinadas generalizaciones, se deben tener en cuenta las particularidades, el "margen".

Para este autor (1988), la Criminología es

(...) el saber (conjunto de conocimientos) que nos permite explicar cómo operan los controles sociales punitivos de nuestro margen periférico, qué conductas y actitudes promueven, qué efectos provocan y cómo se los encubre en cuanto ello sea necesario o útil para proyectar alternativas a las soluciones punitivas alternativas menos violentas que las existentes $y$ más adecuadas al progreso social (p. 20).

Dentro de la corriente crítica, se encuentra la denominada Criminología de los Derechos Humanos. Este modo de entender a la criminología tiene como exponente a Alessandro Baratta ${ }^{x x}$, quien sostenía que todo sistema penal, debe basarse en un derecho penal mínimo en donde lo que se encuentren priorizados sean la prevención (control proactivo) y la víctima, prescindiendo de 
los conceptos de delito y pena (que se desarrollan en el apartado siguiente), para poner foco en los orígenes del conflicto. Su planteo incluye una posición abolicionista penal (Aniyar de Castro, L.; Codino, R. (2013) P. 309).

El derecho penal mínimo pretende priorizar aquellos requisitos mínimos de respeto de los derechos humanos en la ley penal. De acuerdo con Aniyar de Castro y Codino (2013):

Para Baratta, el concepto de los derechos humanos asume una doble función. En primer lugar, una función negativa, concerniente a los límites de la intervención penal; en segundo lugar, una función positiva respecto a la definición del objeto, posible pero no necesario, según el autor, de la tutela por medio del derecho penal. Es decir, la violación a Derechos Humanos sería el núcleo de lo criminalizable (p.311).

Esa doble función de los derechos humanos son el núcleo de la mínima intervención penal y la base para políticas alternativas al control social punitivo represivo.

Baratta también propone tomar en cuenta un concepto amplio de derechos humanos, que incluya los derechos económicos y sociales y no sólo los individuales, a la hora de fijar criterios para realizar un análisis crítico de los sistemas punitivos. Así, los derechos humanos se constituyen como el límite, pero también como el contenido de la criminología. Una criminología de los derechos humanos.

\section{Criminología mediática}

En el apartado anterior, dedicado a explicar el poder configurador de los medios de comunicación y su influencia en la construcción de subjetividad, se hizo referencia al proceso de manipulación que los tiene como protagonistas.

Si bien en la actualidad se asiste a momentos de fuerte presencia mediática y tecnológica en la vida de las personas, siempre los medios de 
comunicación y la criminología han tenido una relación estrecha, donde los primeros ayudan a legitimar a la segunda y justificar una modalidad de control social punitivo-represivo institucionalizado, desde un modelo reproductivista acrítico. Según Chomsky (2007) "La misma estructura de los medios de comunicación está diseñada para inducir a la conformidad con respecto a la doctrina establecida" (p. 22).

Este autor también plantea que el hecho de que los principales medios de comunicación sean un reflejo de los intereses y perspectivas de los grupos de poder, es algo establecido casi como natural, y debe tenerse en cuenta la influencia de los medios en la población en la construcción del "sentido común", que tendrá sus repercusiones en los resultados electorales. Es por esto por lo que los candidatos y los gobernantes intentarán impedir que el poder mediático construya realidades adversas a sus intereses (Feinmann, 2013, p. 83).

Zaffaroni (2011) dirá que todas las personas tienen una idea formada respecto de la cuestión criminal y que ésta está en relación con la construcción que hacen los medios de comunicación. A eso llama "criminología mediática":

Responde a una creación de la realidad a través de la información, subinformación y desinformación mediática en convergencia con prejuicios y creencias, que se basa en una etiología criminal simplista asentada en una causalidad mágica (p. 365).

Es una criminología que históricamente ha existido y que apela a la creación de realidad, porque lo que va cambiando es la tecnología comunicacional, pero siempre se ha perseguido a un chivo expiatorio, ya sea con carteles en las puertas de las casas, desde un púlpito, o desde los medios masivos.

Por ejemplo, en 1900, Gabriel Tarde ya se había percatado de la influencia extorsiva de los medios de comunicación -en su época representados mayormente por los diarios y periódicos-, notando lo dificultoso de intentar neutralizar los efectos de, por ejemplo, una difamación periodística, 
que no hacía más que aliarse con la credulidad -e ignorancia- de la población. La contracara de esta acción de los medios de comunicación es el silencio cómplice, porque, así como se selecciona información para ser difundida, también se selecciona información para ser ocultada (el silencio sobre las masacres).

En la actualidad, la criminología mediática es considerada como "neopunitivismo", no porque sea nueva en sí misma, sino por los nuevos medios técnicos con los cuales se lleva a cabo en la era de la globalización, representados mayoritariamente por la televisión e internet. Estos medios utilizan, sobre todo, imágenes para comunicar, ya que rige la primacía de lo visual; apelando a una pasivización del espectador, en tanto la imagen va acompañada de una interpretación que es impuesta por quien emite la información. $Y$ se sabe que una misma imagen puede tener más de una interpretación posible cuando se encuentra descontextualizada.

La criminología mediática, crea la división social del "ellos" y el "nosotros", los buenos y los malos: crea esa realidad, construye sentidos. Dice Zaffaroni (2012):

La criminología mediática crea la realidad de un mundo de personas decentes frente a una masa de criminales identificada a través de estereotipos, que configuran un ellos separado del resto de la sociedad, por ser un conjunto de diferentes y malos (p.369).

Esto permite pensar y problematizar acerca de los estereotipos que los medios construyen y reproducen, y cómo éstos son interiorizados por los espectadores. Zaffaroni dice que los medios de comunicación no dejan de ser un segmento del sistema penal -afirmación que se profundizó en otro apartado- en tanto son quienes crean y reproducen los estereotipos que hacen que un ciudadano se enfrente con su vecino, porque lo que rige es la noción del enemigo interno: cualquiera puede ser victimario. En esos casos, la imagen juega un papel primordial, porque alcanza con parecerse a la imagen de quien 
se encuentra indicado como criminal, para empezar a ser señalado como tal y portar la etiqueta.

Es decir, no es necesario cometer ningún hecho específico para ser criminalizado: portar el estereotipo, "ser parecido a...", basta; y, además, se seleccionan acciones delictivas para ser reproducidas, las cuales generalmente tienen que ver con aquellas que atentan contra la vida -asesinatos-, la integridad -abusos y violaciones- y la propiedad privada -robos en la vía pública, comercios o en viviendas-; el resto de los delitos se minimizan o invisibilizan. Esto conlleva la disolución de los lazos sociales, por el "sálvese quien pueda", porque el "ellos" que se construye es poroso, responde a ciertos intereses. Los medios de comunicación, como segmentos del sistema penal, lo único que hacen es continuar con su reproducción, perpetuarlo.

En la criminología mediática, puede verse cómo se va implantando en la subjetividad de la población el enfrentamiento con el semejante vulnerable, al que los medios han etiquetado como el potencial peligroso, naturalizando sus muertes, mostrando la "inseguridad" y ocultando los casos de "gatillo fácil", las muertes sin proceso, en "enfrentamientos", muertes justificadas en la lucha contra la delincuencia. Afirma Zaffaroni (2012):

La introyección de la criminología mediática es muy temprana y potente, sin contar con que se la confirma todos los días en la interacción social: se trata de obviedades, o sea lo que en términos de Berger y Luckmann es algo que se da por sabido, por efecto de larga y paulatina sedimentación del conocimiento, como era una obviedad el poder de las brujas hace seiscientos años, o que la sandía se endurece con el vino aún hoy. Se trata de lo que para Pierre Bourdieu sería lo habitual, el sentido común, lo cotidiano. Es lo que muestra la televisión, lo comentan todos entre sí, se lo confirman unos a otros en la sociedad, se verifica por lo que me cuenta el otro. De este modo se construye el ellos como el mayor -casi el únicopeligro social (p. 371 y sig.). 
Pero la criminología mediática, dice Zaffaroni, no se reduce solamente a los programas o portales de noticias, sino que invaden toda la programación y producción de contenidos televisivos, fílmicos y de series, donde aparece el bueno que persigue al malo, al que hay que combatir para "defender la sociedad". Estas "ficciones", tienen en general el horario central de la grilla televisiva -las horas de las comidas-, haciendo que ingrese más fácilmente en la cotidianidad de las familias. Para que estos personajes sean efectivos y el espectador elija seguir ese programa, los mismos deben tener algún rasgo que le permita identificarse con ellos. Cuanto más cotidianas sean las historias que se narran, más sencillo será que esa serie o novela se instale socialmente.

Esta presión mediática tiene también influencia en los jueces, quienes muchas veces terminan aplicando prisiones preventivas por la repercusión en los medios de un hecho y las posibles represalias que podría tener para su persona, su familia o su función, si decidiera aplicar una medida que garantizara mayor acceso a derechos para el sujeto.

Esto es notorio si se tiene en cuenta que, en América Latina, el 70\% de la población penal la constituyen personas que están bajo prisión cautelar o preventiva. La presión mediática también influye a la hora de otorgar un "beneficio" a un detenido -como puede ser la salida anticipada, libertad bajo palabra o condicional-, casos en los que muchas veces se niega o retrasa un derecho por el posible reproche mediático -y su concomitante escrache social-.

Lo paradójico es que, frente al hecho de la prolongación de las prisiones preventivas, los medios atribuyen esta lentitud a la poca diligencia o burocracia de los jueces, dejando por fuera su propia responsabilidad, no reconociendo su influencia en la población -lo cual, claro, también es funcional a que se continúe reproduciendo su efecto configurador en la sociedad-. Tampoco reconocen su incidencia en la producción de legislación: "De la criminología mediática -como de cualquier otra- se desprende una política criminal o criminológica" (Zaffaroni, 2012, p.380). 
Se puede citar sólo como algunos ejemplos, la ley de Blumberg ${ }^{x \times i}$ (el secuestro y asesinato de un joven de clase media que influyó en la opinión pública para endurecer las penas), la Ley de Trata ( que fue impulsada fuertemente a partir del tratamiento sobre la temática por la telenovela "Vidas robadas"xxii), la Ley de Obesidad (llevada al Congreso por el programa "Cuestión de Peso"xxiii), el tratamiento diferencial que se le da al tema de la despenalización del aborto dependiendo si la intencionalidad editorial es estar a favor o en contra -dejando de lado toda objetividad en el abordaje del tema-; en estos ejemplos, la influencia mediática es notoria y visible, en otros casos, resulta menos precisa, pero no por eso es menos eficaz.

Sostiene Zaffaroni (2012) que una de las figuras centrales de la criminología mediática, es la de la "víctima héroe". No es cualquier víctima de delito, sino aquella que reúne ciertas características que le permite a los medios hacer uso de ella para reforzar la idea de la necesidad de mayor control social punitivo represivo.

En ocasiones, la criminología mediática da con la víctima ideal, capaz de provocar identificación con un amplio sector social y en tal caso la convierte en vocera de su política criminológica, consagrándola como víctima-héroe (Pág. 386).

Esta víctima-héroe, es doblemente víctima. En principio, del acto delictivo que la ha tenido como protagonista, y, en segundo término, de los medios de comunicación, quienes luego de hacer uso de ella, cuando la víctima se vuelve inmostrable por ya no ser funcional a los fines perseguidos, se la ignora, silencia y abandona, dejándola sola y sin contención para su padecimiento psíquico y emocional.

Uno de los mayores efectos de la criminología mediática -además de la criminalización- es el de fomentar en la población una "indiferencia moral". En palabras de Zaffaroni (2012): 
Lo que hace es sostener nuestra indiferencia por el sufrimiento de ellos, así como todo el estado alemán sostuvo la indiferencia frente al aniquilamiento de los judíos, gitanos, disidentes, gays y marginales, o sea, que promueve la falta de empatía y de participación emocional en el sufrimiento de los otros, lo que no es más que un capítulo previo a su eliminación (...) En rigor, elegir víctimas para producir empatía y manipularlas para provocar odio hacia ellos e indiferencia frente a una posible eliminación, es lo más inmoral que puede imaginarse (Pág. 390). 


\section{TEORÍA DEL DELITO Y DE LA PENA}

Palabras clave: delito, pena, imputabilidad, inimputabilidad

Este apartado intenta desarrollar conceptualmente qué es lo que justifica jurídicamente a la pena y la relación entre la pena y el castigo. El objetivo es poder, a partir de esas definiciones, poner en crisis la situación de las personas que por un padecimiento mental o por no comprender al momento del hecho la antijuridicidad de éste, son declaradas, por ley, inimputables, imponiéndoseles, no obstante, una "medida de seguridad". Ésta es entendida desde el derecho como una categoría distinta de la pena, pero, sin embargo, en la aplicación en lo real, no se diferencian mucho.

El interrogante que se toma como punto de partida es: la pena privativa de la libertad, ¿cumple una función positiva en la sociedad? Para esto se analizan la teoría de la pena y la teoría del delito, par complementario del sistema punitivo. El momento de procesar a un sujeto, que es el momento de la criminalización secundaria, dirán Zaffaroni, E., Alagia, A., Slokar, A., (2006), supone dos instancias:

(a) un primer orden sirve para verificar si están dados los presupuestos para requerir de la agencia judicial una respuesta que habilite el ejercicio del poder punitivo;

(b) dados esos presupuestos, un segundo sistema pregunta cómo debe responder la agencia jurídica a ese requerimiento (pág. 288).

El primer caso es el denominado teoría del delito y el segundo la teoría de la pena. Este último debe entenderse como una teoría de la responsabilidad penal o punitiva de la agencia jurídica, no del criminalizado, pues quien responde es la agencia y lo hace velando para que el poder punitivo no recaiga en forma intolerablemente irracional sobre el procesado.

Delito y pena también se encuentran en relación directa en que ambos guardan valoración negativa: en tanto la imposición de un castigo tiene como 
precedente la retaliación, la pena no puede nunca tener valoración positiva. Tanto delito como pena son lesiones: "La pena como retribución a un mal no puede ser sino un mal” (Messuti, 2008, Pág. 29).

Se hace necesario realizar este recorrido esclarecedor respecto a la teoría del delito y de la pena, dado que lo que se suele encontrar en el tratamiento mediático de los casos jurídicos, son abordajes desde el sentido común, cargados de aspectos valorativos por parte de los periodistas que relatan los sucesos.

Cuando los periodistas abordan noticias judiciales, lo hacen desde la generalidad, porque a no ser que estén formados en derecho, lo que los acompaña es la ignorancia y lo que se produce es una multiplicación de la desinformación (Villarruel, 2014).

Se escucha en los medios utilizar términos como "condenado", "prisión preventiva", "fianza", “careo", "excarcelación”, "reclusión” en forma vaga, imprecisa y con una ligereza que luego no se corrige (Villarruel, 2014, pág. 22).

La mayoría de las veces el uso de esas etiquetas tiene que ver con o bien con la ya mencionada ignorancia del comunicador, o bien con la necesidad de titular en forma llamativa para generar alto impacto en la audiencia, lo cual no hace sino contribuir a deformar la situación, siempre en perjuicio del sujeto señalado como el presunto responsable de la situación. "Las penas de prisión se cumplen en la cárcel y algún día terminan. La condena mediática, en cambio, no prescribe nunca" (Villarruel, 2014, Pág. 216).

\section{El poder punitivo y la pena}

Para Zaffaroni, la pena se define por lo que no es, por la negativa: por ejemplo, no resocializa, no previene el delito; no se puede asegurar lo que hace la pena en la realidad. $Y$ esto es porque el fenómeno punitivo es más amplio que el tema de la pena en la realidad: amplía el campo de estudio del derecho penal, no reduciéndolo solamente a la pena legal. El autor sostiene 
que nadie sabe a ciencia cierta cuáles son las funciones de la pena, sólo existen respuestas parciales frente a la pregunta y todas hacen referencia a "para qué serviría" (definiciones más bien utilitarias, dadas de acuerdo con situaciones particulares), donde unas veces sirve para una cosa y otras para otra. Afirman Zaffaroni, E., Alagia, A., Slokar, A., (2006):

(...) hace pelear a los excluidos y marginados, con lo cual los mantiene distraídos; permite sacarse de encima a algún enemigo poderoso retirándole cobertura en cierto momento; renormaliza situaciones desnormalizadas a través de la entrega de diplomas de víctimas; proporciona votos a los políticos; es fuente de recursos extrapresupuestarios para las agencias; permite subir el precio de lo prohibido cuando se lo encara empresarialmente; puede ser útil para eliminar disidentes; tranquiliza a la opinión pública; permite montar industrias de seguridad; etc.(pág. 55).

Y añaden los autores:

"De cualquier manera la multiplicidad de funciones hace imposible su definición positiva y, además, como buena parte de sus funciones reales (engañar a la población, función latente) no son éticamente positivas ( $\mathrm{y}$ otras veces son ellas mismas criminales), en caso de alcanzarse esa definición positiva no sería apta para ser incorporada al discurso jurídicopenal (no podría el Estado asumir como propia una definición según la cual el poder punitivo se caracteriza por su utilidad para eliminar disidentes, neutralizar excluidos y proveer recaudación ilícita (pág. 55).

Así, el concepto de pena no sólo necesariamente se define por la negativa, sino que, además, se sostiene que es imposible agotar el conocimiento de sus funciones, lo que lo convierte también en un concepto agnóstico: "la pena y su utilidad no es y no puede ser una cuestión de fe" (Zaffaroni; Alagia; Slokar, 2006. Pág. 55. La bastardilla es del original). No puede sostenerse "yo creo que, yo no creo que", le quitaría al Derecho su característica certeza. 
Esta conceptualización negativa de pena, la consideran los autores como: “(a) una coerción, (b) que impone una privación de derechos o un dolor, (c) que no repara ni restituye, (d) ni tampoco detiene las lesiones en curso ni neutraliza los peligros inminentes" (Zaffaroni; Alagia; Slokar, 2006. Pág. 56. La bastardilla es del original).

Así enunciado, el concepto de pena no sólo es negativo porque se obtiene por exclusión, sino que también lo es porque no se le otorga ninguna función positiva.

Ana Messuti (2008) sostiene que para definir la pena es fundamental conocer y distinguir lo que corresponde a la víctima y lo que corresponde a quien ha delinquido:

Lo que corresponde a la víctima se funda en el derecho de ésta a recibir una reparación por el daño sufrido. Pero la pena, como correspondiente al delincuente, se funda también en un derecho, que es a la vez un deber, pero no ya de la víctima sino de la comunidad de personas, porque la comunidad de personas como tal se convierte en destinataria indirecta de toda lesión a una persona, dado que considera que cada lesión a una persona amenaza, pone en peligro a toda la comunidad. De ahí que no sólo interese "lo que se restituye a la víctima" sino, muy especialmente, "lo que sucede al agente. $Y$ lo que sucede al autor del delito es precisamente la pena como retribución de la comunidad de personas que se ha visto amenazada por su acto (pág. 24).

De este modo, y teniendo en cuenta que en nuestro país la pena, casi en todos los casos, implica la privación de libertad, la autora retoma lo planteado por Foucault en "Vigilar y Castigar" (2008) quien sostenía que:

Hay una forma-salario de la prisión que constituye, en las sociedades industriales, su "evidencia" económica. Y le permite aparecer como una relación. En efecto, al apropiarse del tiempo del condenado, la prisión parece traducir concretamente que el delito ha lesionado, no sólo a la víctima, sino a la sociedad entera. Evidencia económica-moral de una 
penalidad que monetiza los castigos en días, meses, años, y que establece equivalencias cuantitativas: delitos-duración (pág. 234).

Y esto es así porque el dispositivo "cárcel" tiene su contexto de surgimiento en la época de las revoluciones (Industrial y Americana), donde la capacidad y posibilidad de producción comienzan a ser lo más importante; es por eso que quien no produce (homeless, locos, niños no escolarizados, ancianos, delincuentes, etc.) son encerrados (en hospicios, manicomios, hogares, institutos, escuelas, geriátricos, cárceles), y quienes deben ser castigados lo son en función de perder lo más valioso: el tiempo. El tiempo como castigo.

La pena posee dos elementos fundamentales: el tiempo y el espacio, siendo el primero el de mayor relevancia. El espacio suele ser siempre el mismo, la institución de encierro. La variable es el tiempo, y es el más importante en tanto no es igual estar una semana en una cárcel que toda la vida. Además, el ser humano también es tiempo, es un elemento tan propio como la misma biología. Dice Alagia (2013):

La doctrina de la pena en tanto trato cruel para bien de la sociedad es ideológica si por ello se entiende la promoción de una creencia orientada a la acción ruinosa al presentar lo falso como verdadero, la crueldad como "bello trato" (pág. 284 y sig.).

El poder punitivo es de competencia de la autoridad -fenómeno irracional meramente político-, lo cual da por resultado una contradicción entre lo que se dice de la pena y lo que la pena hace en la realidad.

La pena, generalmente -aunque no en todos los casos, se abordará más adelante- es el corolario de una situación o acción delictiva, y se le impone a un sujeto para intentar "retribuir" a la sociedad por el mal cometido. Pero para poder arribar a un juicio en el cual se le imponga una pena privativa de la libertad a una persona, antes debe poder atribuírsele la comisión de un delito. 


\section{El concepto de "delito" y sus elementos}

Si bien desde el derecho se propone una definición de delito basada en cuatro elementos: conducta típica, antijurídica y culpable (que más adelante se desagregan para explicarlos), no debe comprenderse como una sumatoria de elementos, sino como "un doble juego de valoraciones acerca de una acción humana que en cada caso la pretensión de ejercicio del poder punitivo debe superar, para que los jueces puedan habilitar su paso en determinada cantidad y forma" (Zaffaroni, Alagia, Slokar, 2006, pág. 295).

Zaffaroni (2013) sostiene que el concepto de "delito" resulta oscuro y es el que habilita a la práctica punitiva, a la pena. Debe pensarse al castigo desde Foucault (2008), como un acto de refundación de la sociedad, donde juega un papel importante a la hora de definir a una acción como delictiva o no, el proceso de criminalización sobre el acto y sobre el sujeto - y muchas veces más sobre el sujeto que sobre el acto-. Dice Zaffaroni (2013):

Resulta claro que el "concepto jurídico de delito" no es tal, sino que es la síntesis de los requisitos que debe presentar cualquier acción conflictiva de un autor seleccionado por el poder del sistema penal, para que la agencia judicial responda afirmativamente en cuanto al avance del proceso de criminalización en curso (pág. 253, bastardilla en el original).

Del amplio abanico de acciones conflictivas que se encuentran tipificadas en el Código Penal como delictivas, son muy pocas las que efectivamente luego son seleccionadas por el poder punitivo para ser castigadas. $Y$ tampoco cualquier sujeto será criminalizado, juzgado y castigado. Entra en juego en este caso, la característica fuertemente selectiva del Sistema Penal para determinar en qué delitos se pondrá el foco y seleccionará la clientela para ellos. Es por esto por lo que Zaffaroni sostiene que "EL" delito, no existe, sino que son acciones conflictivas arbitrariamente seleccionadas por quien se encuentre en ese momento administrando las decisiones a nivel jurídico-penal.

En este sentido, los medios de comunicación contribuyen incrementando la sensación de inseguridad en la población y fomentando el descrédito en el 
accionar de la justicia, sosteniendo y difundiendo mitos ("entran por una puerta y salen por la otra", "pagó y quedó libre", "el detenido tenía antecedentes y estaba libre", "acá nadie va preso", etc.) que luego son repetidos por las personas y que sin embargo, se basan en la ignorancia respecto al funcionamiento del Sistema Legislativo y Penal Argentino.

El sentimiento de inseguridad se incrementa y se moldea por la espectacularización mediática de los hechos seleccionados para su difusión, sobre todo de ciertos delitos en particular en donde los damnificados suelen ser personas de los sectores altos o medio-altos. Lo interesante es que es sensación de inseguridad que experimentan los sujetos a partir del tratamiento mediático de los hechos, no siempre tiene correspondencia con sus propias experiencias de victimización, esto tiene que ver con la influencia que tienen en la actualidad los medios de comunicación en la vida cotidiana de los espectadores (Villarruel, 2014. Pág. 97).

\section{Elementos constitutivos del delito}

\section{1) Conducta, acción}

La conducta constituye el sustantivo en la definición de delito, del cual el resto de los elementos son adjetivos. No puede haber crimen ni pena sin conducta y se considera como tal a un acto humano voluntario, por eso se utiliza el concepto antropológico de conducta o acción, porque remite a lo humano; un animal no comete acciones delictivas, no puede atribuírsele ese grado de autonomía para direccionar sus movimientos ni la racionalidad intencional.

Si se analiza críticamente cómo se imponen las penas, puede notarse que el poder punitivo se ha caracterizado por perseguir crímenes sin conducta, bajo el estado de sospecha. De este modo no describe conductas sino estados.

No hay pena sin delito, pero fundamentalmente no hay pena sin conducta, y esto tiene que ver con acotar la criminalización no a los sujetos por sus 
características, por lo que son (por su color, género, nacionalidad, edad, condición social, etc.) sino a la acción cometida, que debe comprender un conflicto, la lesión de un bien jurídico ajeno.

La conducta tiene más de descriptivo que de valorativo; la tipicidad, en cambio, es el segundo escalón y es valorativa. Una acción conflictiva, en sí misma, no constituye delito, sino hasta que se pone en análisis su relación con algún tipo jurídico.

\section{2) Típica}

La ley, a partir de las Revoluciones, se escribe en Códigos Penales. No hay delito y no hay pena si no hay ley previa. Una conducta puede ser considerada como delito según Zaffaroni, Alagia, Slokar, (2006):

(...) cuando una ley la criminaliza (la llamada criminalización primaria). Para eso las leyes se valen de fórmulas legales que señalan pragmas conflictivos (conductas, circunstancias y resultados) que amenazan con pena y que se llaman tipos, escritos en la parte especial del código penal y en leyes penales especiales (no codificadas). (pág. 339).

La tipicidad es la adecuación de la acción al tipo. Si lo ilícito es contrario al derecho es porque está prohibido ("no matarás"). También está tipificada la omisión (omisión de ayudar, por ejemplo, en la figura del abandono de persona). Para que una conducta pueda ser tipificada como delito, debe tener basamento en la realidad. Pero la interpretación de la tipicidad se encuentra necesariamente ligada a un juicio valorativo (jurídico) por el cual se intenta determinar si una acción real y concreta es típica, es decir, si constituye materia prohibida.

Acción, omisión, imprudencia activa e imprudencia omisiva son las cuatro estructuras de la tipicidad penal. La primera regla de imputación de la tipicidad es encontrar la causalidad. 
Para Belzer, en la intención y la imprudencia debe tomarse a la intención como fundamento del escalón valorativo de la tipicidad. A partir de allí, el eje de imputación no es la causalidad sino la intención. Sigue siendo la idea dominante, pero está en crisis. Este autor introduce peso subjetivo en la tipicidad y esto la complejiza, porque es objetiva (la letra del Código, la Ley) y subjetiva (intencionalidad de la acción, propia del sujeto, materia de análisis para el juez).

Ahora bien, la causalidad es insuficiente para la imputación. La intención es un simple deseo, está vinculada con la racionalidad en donde se buscan los medios idóneos para cometerla. Pero la intención es un dominio de la causalidad en donde lo subjetivo domina a lo objetivo. Cuando el sujeto tiene dominio sobre la acción que comete, se está frente a un autor de delito de tipo doloso. "Tiene dominio del hecho quien dispone sus condiciones, su sí, su cuándo, su cuánto, su cómo, su dónde, etc." (Zaffaroni; Alagia, Slokar, 2006, Pág. 396. La bastardilla es del original).

Para Zaffaroni (2012), sólo si el sujeto ha podido dominar la causalidad, se puede pensar en la tipicidad: es la condición de dominabilidad.

La tipicidad objetiva tiene en su interior otros escalones valorativos, uno de ellos es la tipicidad sistemática (análisis de las palabras de la ley y la causalidad). Otro escalón es la tipicidad conglobante, más abarcadora que la causalidad y la palabra de la ley, se debe entender a la norma como formando parte de un universo de leyes que deben ser interpretadas dentro de un orden normativo; también debe atenderse a la dominabilidad, la racionalización de la acción, tiene que ver con el aspecto consciente; el otro momento de la tipicidad conglobante es la conflictividad lesiva, allí se introduce el consentimiento, que elimina la tipicidad porque es el uso de un derecho.

El consentimiento de la víctima no evita la lesión, pero libera al autor de ser el protagonista de un acto lesivo, no hay conflicto. Cuando hay delito sin víctima, no hay conflicto entre las partes, pero hay una afectación al Estado. Por último, dentro de la conflictividad lesiva debe haber la lesión de un bien 
jurídico, sin lesión no hay conflicto (aunque puede haber lesión sin conflicto, cuando hay consentimiento). (Zaffaroni, Alagia, Slokar, 2006, Pág. 371).

La acción conflictiva no solamente debe poder ser analizada desde los tipos jurídicos, sino que se debe poder confirmar que no existe permiso de la ley para que autorice esa conducta, es decir, debe ser antijurídica.

\section{3) Antijurídica}

Lo antijurídico es ir en contra del derecho, sostienen Zaffaroni, Alagia, Slokar (2006)

(...) es la contradicción de la conducta con el orden jurídico. La conducta penalmente típica es antinormativa, pero no es antijurídica aún, porque puede estar amparada por un precepto permisivo (causa de justificación), que puede provenir de cualquier parte del orden jurídico. Cuando la conducta típica no está amparada por ninguna causa de justificación, ya no sólo es antinormativa, sino también antijurídica (pág. 371).

Conociendo los mandatos y prohibiciones, se sabe lo que está permitido: lo que no está prohibido. Así, la antijuridicidad estaría dada a partir del choque entre la conducta del sujeto y la totalidad del orden jurídico funcionando como tal.

Los derechos enunciados en la Constitución Nacional y por el Derecho Internacional de los Derechos Humanos, son un resto de lo que manda la autoridad, es lo no regulado punitivamente, deben entenderse como límites al poder de interferencia del Estado. Es decir que hay delito siempre y cuando no entre en contradicción con un derecho del sujeto.

Asimismo, aunque exista una acción conflictiva, que se haya analizado desde los tipos jurídicos y se haya confirmado como antijurídica, debe todavía evaluarse el contexto de producción de la conducta, y determinar la imposibilidad del sujeto de tomar otra dirección más que esa, si se ha obrado 
en el modo menos lesivo teniendo en cuenta las circunstancias y el estado de conciencia de la persona (alteración o perturbación de ésta). Este juicio es el que permitirá saber si le cabe al individuo un reproche jurídico, es decir, culpabilidad y exigibilidad de responsabilidad.

\section{4) Culpable}

La culpabilidad, implica una "deuda": se le debe algo a alguien. En el discurso del sistema penal, ese "algo" viene a ser el injusto y el modo en que se cobra esa deuda, es con la pena. Por lo tanto, la culpabilidad es la exigibilidad de evaluar la intención o autodeterminación del sujeto. Es un juicio que se hace sobre la posibilidad del sujeto de poder hacer otra cosa: ¿pudo no haber matado? Si no hay posibilidad de actuar de otro modo, falla el principio de autodeterminación y no hay culpabilidad -es el caso, por ejemplo, de la legítima defensa-.

La culpabilidad es definida por Zaffaroni, Alagia, Slokar (2006) como

(...) el juicio necesario para vincular en forma personalizada el injusto a su autor y, en su caso, operar como principal indicador del máximo de la magnitud de poder punitivo que puede ejercerse sobre éste. Este juicio resulta de la síntesis de un juicio de reproche basado en el ámbito de autodeterminación de la persona en el momento del hecho (formulado conforme a elementos formales proporcionados por la ética tradicional) con el juicio de reproche por el esfuerzo del agente para alcanzar la situación de vulnerabilidad en que el sistema penal ha concretado su peligrosidad, descontando del mismo el correspondiente a su mero estado de vulnerabilidad (pág. 520).

No hay acción sin intención, que es lo que permite anticipar. Esa anticipación del resultado es la finalidad, que es lo que admite seleccionar los medios, y no hay acción sin medios. Será la evaluación de la autodeterminación del sujeto que comete determinada acción, lo que otorgará 
al sistema punitivo un mínimo de racionalidad. Teniendo en cuenta que todas las personas son distintas, se hará necesario evaluar en cada caso qué tipo de autodeterminación tenía el sujeto al momento de la realización del acto; para esto se deberá atender a las condiciones personales, la situación o coyuntura particular de desencadenamiento de la acción, y el contexto circunstancial general.

El ilícito objetivo va acompañado de una voluntad que está manipulada por la subjetividad: esto inaugura lo ilícito complejo. El gobierno de la intención dirige el ilícito, lo que lo convierte en algo intencional. Un homicidio no es culpable porque es intencional, sino que lo ilícito es lo que determina la intencionalidad. El juez lo que debe develar es si cierta acción causó un resultado; luego, determinar si esa conducta está guiada por una intencionalidad y se le reprocha al sujeto lo que hizo (la acción típica antijurídica) y no lo que es (que encuadraría en el derecho penal de autor). Afirman Zaffaroni, Alagia, Slokar (2006):

Esto no significa que para establecer el juicio de reproche personalizado no deba tomarse en cuenta la personalidad del agente, pues forma parte de la circunstancia en que actuó. Pero la personalidad juega un papel muy diferente, según se la tome en cuenta en una culpabilidad de acto (liberal y constitucional) o en una culpabilidad de autor (de carácter, de personalidad, de conducción de vida o como quiera llamársele), es decir, dentro de un esquema autoritario e inconstitucional. (Pág. 510. Bastardilla en el original).

Para Zaffaroni (2012), el dolo no funda lo ilícito, sino la intención como aquello que define lo doloso de lo culposo, lo intencional de lo imprudente.

Resulta importante conocer esta definición jurídica de delito y sus diferentes componentes, para comprender las decisiones que muchas veces se toman desde el poder judicial y que en general son malinterpretadas por los medios y esto es transferido a la comunidad. 
El hecho, por ejemplo, de que la pena sea proporcional -jurídicamente hablando- a la gravedad y circunstancias del caso, muchas veces es abordado por los medios desde la "injusticia" cuando no se aplica la pena máxima frente a situaciones que resultan sensibles. Como sostiene Villarruel (2014)

Por ejemplo, hubo casos donde a los acusados se les han dado 20 años de prisión y algunos medios titularon: "Exigua pena para quien mató a su pareja". Si el monto de la pena es de 8 a 25 años, 20 años, desde el sentido común, está más cerca del máximo que del mínimo posible. Conocido el fallo, se les pregunta a los familiares de la víctima si 20 años no les parece poco. Una pregunta que intenta inducir la respuesta. Es extraño pensar que los familiares quedarán conformes ya que no recuperarán a su ser querido, ni con 25 años ni con condena perpetua. En todo caso, la pregunta podría ser si están conformes con el fallo (pág. 43).

En este sentido, se debe apelar a la prudencia por parte de los medios en el tratamiento que realizan de las noticias judiciales, ya que la mayoría de las veces lo que se difunde se hace sin fuentes documentales respaldatorias ( $\sin$ lectura ni conocimiento del expediente, por ejemplo) y sin chequear lo que se publica o difunde, generando confusión en la población y el descreimiento en el poder judicial, dando pie al surgimiento de las condenas sociales que en nada condicen con los elementos presentes en la investigación judicial (Villarruel, 2014. Pág. 46).

\section{El caso de la inimputabilidad: no culpabilidad, ¿no pena?}

La culpabilidad jurídica, requiere de la comprensión de la antijuridicidad, su internalización, y cierto grado de autodeterminación. Quedan por fuera de la posibilidad de recibir un reproche jurídico, aquellos comprendidos por el artículo 34 del Código Penal Argentino y no hay -o no debería haber- pena sin reprochabilidad. 
Cuando se analizaron los elementos de la definición de delito, se particularizó que no es posible que haya conducta sin capacidad de voluntad: "para reprocharle una conducta típica y antijurídica (un injusto o ilícito penal) a un autor es menester que éste haya tenido cierto grado de capacidad psíquica, que le hubiera permitido disponer de un ámbito de autodeterminación" (Zaffaroni, Alagia, Slokar, 2006, Pág. 540. Bastardilla en el original).

No debe interpretarse que las personas "son" imputables o inimputables, sino que la imputabilidad es una característica del acto que proviene de la capacidad del sujeto. Los injustos realizados son imputables o no de acuerdo con la capacidad psíquica del autor al momento de la acción en cuestión.

Cuando se pierde de vista esta aclaración, y el análisis se centra no en el acto, su contexto y la situación de capacidad del sujeto en ese momento, sino en el diagnóstico o características de la persona, entra en escena el denominado "derecho penal de autor", donde se interpreta al delito como síntoma de un estado del sujeto, el cual es considerado "anormal"; cuando las facultades mentales de quien comete el ilícito se encuentran alteradas, se trata de un "estado peligroso" (Zaffaroni, Alagia, Slokar, 2006, Pág. 49).

Si se determina la inimputabilidad por una acción a una persona, no se le puede realizar un reproche jurídico por su acto. Pero lejos de dejar al sujeto sin un castigo, se produce una respuesta por parte del Derecho Penal, imponiendo una medida de seguridad, que no deja de ser una pena encubierta. Sostienen Zaffaroni, Alagia, Slokar (2006):

Medidas de seguridad (también llamadas, últimamente, medidas de tratamiento, corrección y educación). Estas penas (rebautizadas como medidas) se clasifican en la doctrina dominante en (a) medidas para inimputables cuando se destinan a locos y lunáticos; (b) posdelictuales cuando se destinan a quienes cometieron delitos, pero no por los delitos cometidos sino por las molestias que les causan a la burocracia, y (c) predelictuales cuando están dirigidas contra la gente sospechosa. Con las primeras se eliminan los locos de la calle, con las segundas se ahorra el trabajo de perseguir a rateros y se vacían las cárceles y, con las terceras, 
se abre una enorme fuente de explotación que degrada al sistema penal (Estado) a la condición de partícipe en los beneficios de la prostitución, el juego y otras actividades análogas (Pág. 52. Bastardilla en el original).

Las medidas de seguridad que se imponen a las personas que son declaradas inimputables de una acción cometida, consideradas incapaces del delito en cuestión, implican en su mayoría la privación de libertad "para su tratamiento" por tiempo indeterminado ("hasta que cese la peligrosidad", dice el artículo 34 del Código Penal). Estas medidas se cumplen efectivamente, en su mayoría, en Unidades Penitenciarias. La reclusión hace que no se diferencie de una pena en sí misma sino sólo en el hecho de que esta última posee un límite en el tiempo. La carencia de tiempo máximo de encierro para las medidas de seguridad genera una desproporción entre la acción cometida y su castigo si la persona hubiese sido declarada imputable, con su concomitante sufrimiento.

\section{De acuerdo con el Fallo Gramajo}

(...) las únicas medidas de seguridad en la ley argentina son curativas. No existen en nuestra ley medidas de seguridad que se limiten a meras privaciones de la libertad y que se ejecuten igual que la pena de prisión, lo cual es perfectamente razonable y constitucionalmente viable, pues ninguna pena, por el hecho de imponerse con relativa indeterminación temporal y privársele de algunos beneficios ordinarios deja de ser pena: dicho en otras palabras, una pena que adopta condiciones más gravosas no es menos pena que sin esas condiciones; en última instancia sería una pena más grave, pero nunca perdería su naturaleza de pena.

Ahora bien, lo que se observa cuando una acción delictiva es cometida por una persona que por ley es considerada inimputable, es que los medios de comunicación construyen sentidos e imaginarios que no se corresponden con el marco legal vigente. Suele darse por "culpable" al sujeto -incluso antes de poder comprobarse su responsabilidad o no en el hecho del que se lo acusa-, etiqueta que luego es muy difícil -por no decir imposible- desinstalar, y que 
puede promover la aplicación de medidas de seguridad punitivas por sobre un abordaje terapéutico relacionado con la salud mental -como se podrá advertir cuando se realice el análisis del caso del "loco del cuchillo" de Berisso-.

\section{Delito y vulnerabilidad}

Zaffaroni (2013) plantea que delito y pena están separados por un abismo e introduce una dogmática en donde cada elemento cumple una función de reducción de los fenómenos irracionales de la pena. Habilita pena, pero deshabilita lo irracional. Manifiesta que el Derecho Penal, debería ser un límite al poder punitivo: cuando el poder punitivo no encuentra límites, se desborda sobre toda la población.

En el caso de la imposición de medidas de seguridad sobre personas declaradas inimputables de una acción, se está frente al desborde del poder punitivo sobre un sector de la población que, por ley, debiera ser protegido por su mayor grado de vulnerabilidad. "En el crimen común el hecho punible es causa de la pena a condición de un estado y situación de vulnerabilidad" (Alagia, 2013. Pág. 302).

Se hace mención, de este modo, a un concepto que plantea Zaffaroni (2013) que es el de "vulnerabilidad socio-penal", que refiere a la mayor posibilidad de ciertos sectores de la sociedad de ser captados por el Sistema Penal para entrar el contacto con él. Se verifica en el caso de la imposición de medidas de seguridad a personas declaradas inimputables, pero igualmente encerradas por su potencial "peligrosidad" y también en la selección que se hace mediante la criminalización secundaria, es decir, qué grupos serán los indicados como posibles "delincuentes", y que portarán una etiqueta por la que serán vigilados, señalados y recibirán un trato a consecuencia de ésta. Dice Zaffaroni (2013):

Cuando una persona se coloca en situación de vulnerabilidad es cuando el sistema penal la selecciona y la instrumenta para justificar su propio 
ejercicio de poder. [...] es el grado de vulnerabilidad al sistema penal lo que decide la selección y no la comisión de un injusto, porque hay muchísimos más injustos penales iguales o peores que dejan indiferente al sistema penal (pág. 275).

El riesgo de portar estas etiquetas estigmatizantes es que, a mayor vulnerabilidad del sujeto, menor autonomía para poder decidir algo diferente a ese rol previa y anticipadamente asignado (porque no es necesaria la comisión de una acción delictiva para ser señalado como delincuente, basta portar el estereotipo), el cual sostiene Zaffaroni (2012), que muchas veces es asumido por el sujeto:

\begin{abstract}
Son muchos los que externamente cargan con un estereotipo, pero no todos lo introyectan y asumen el rol conforme a éste. En la vida cotidiana y respecto de estereotipos positivos, sucede lo mismo. Las características personales que nos lleva a asumir un estereotipo no son patológicas ni mucho menos [...] La fragilidad personal indica el riesgo de criminalización y de cambio de autopercepción que se corresponde con la peligrosidad individual del poder punitivo. Se trata del peligro que el sujeto concreto corre frente al poder punitivo, tanto de ser criminalizado como de asumir el rol y cambiar su autopercepción y pasar a responder a los requerimientos del estereotipo asumido (Pág. 331 y 332 . Bastardilla en el original).
\end{abstract}

En el caso de las personas con padecimiento mental, no se puede afirmar que en todos los casos su situación se deba a una asunción de un rol previamente asignado. Sí surge de la lectura de noticias periodísticas, que muchas veces ante la ocurrencia de una acción delictiva grave cometida por una persona con padecimiento mental, en las "entrevistas" a vecinos, familiares y amigos, aparecen comentarios como "era una bomba de tiempo", "sabíamos que algún día iba a pasar algo así". Esto tiene que ver con que portan la etiqueta del "loco peligroso".

Estas construcciones socioculturales de etiquetas, no sólo quedan allí, sino que también suelen atribuirles a los sujetos determinadas características, 
como el sostener que la declaración de inimputabilidad en una persona que ha cometido una acción antijurídica es un camino hacia la impunidad, cuando en lo real y concreto -ya se ha dicho- se puede corroborar que ese sujeto, lejos de quedar sobreseído y en libertad, es sobreseído y se aplica una medida de seguridad, sin una pena prefijada que le permita conocer en qué momento podrá estar en libertad. Es decir, el sentido común realiza una construcción imaginaria de lo que significa ser inimputable, perdiendo de vista los efectos que esto trae sobre el sujeto que porta esa declaración.

La legislación vigente le deja al juez un margen de discrecionalidad absoluta para disponer la internación (una forma de privación de la libertad, según la $\mathrm{CIDH}$ ) de la persona en una institución penal especializada sin límite temporal especificado y más allá del tipo de delito en cuestión. La única indicación del texto vigente es que esa privación de la libertad sólo puede concluir cuando un examen de peritos determine que ha "desaparecido" el peligro de daño para sí mismo o a otras personas. El encierro se prolonga mucho más del que le habría correspondido de haber sido hallado imputable y de haber cumplido con la pena que le cabe al delito cometido, de acuerdo con el Código Penal.

Si bien se estipula en dicho código que en los casos de inimputabilidad, la medida de seguridad debe ser curativa y se menciona la "internación" - dando posibilidad al alojamiento en hospitales que atiendan salud mental-, la privación de libertad en Unidades Penitenciarias Psiquiátricas sigue siendo la medida privilegiada, aun encontrándose vigente la ley Nacional de Salud Mental N. ${ }^{\circ}$ 26.657, y teniendo las recomendaciones de CONISMA (Comisión Nacional Interministerial de Políticas de Salud Mental y Adicciones) que indican que las medidas que deben utilizarse siempre han cumplirse en instituciones de salud; así, el "tratamiento" que recibe el sujeto es o bien medicalización o bien aislamiento, cuando no una combinación de ambos, entrando en los términos de la "eliminación" de lo social.

¿Cómo deconstruir imaginarios sociales apuntando a una integración de personas con padecimiento mental y que no impliquen una respuesta punitiva? 
Muy lejos se está de poder vislumbrar un punto de llegada, pero un buen punto de partida son los Derechos Humanos (que son también la respuesta que encuentra Zaffaroni (2013) al pensar en cómo revertir los efectos deteriorantes que produce el Sistema Penal en general). Los Derechos Humanos como límite al poder punitivo, tal como sostienen Aniyar de Castro y Codino (2013):

Los Derechos Humanos han sido, pues, propuestos como límite y como objeto del Derecho Penal. Esto quiere decir que los Derechos Humanos son el límite de la intervención punitiva del estado; que el Derecho Penal no está legitimado si no contribuye a disminuir la violencia punitiva. $\mathrm{Y}$, por lo tanto, que también los Derechos Humanos son el límite y deben ser el contenido de la misma Criminología (Pág. 322. Bastardilla en el original).

Así como los medios construyen imaginarios, también se hace necesario incorporarlos como promotores en la deconstrucción de sentidos e imaginarios en relación con las etiquetas asignadas a las personas a las que se les supone la comisión de una acción antijurídica. 


\section{LA NOCIÓN DE “PELIGROSIDAD” COMO JUSTIFICATIVO PARA LA APLICACIÓN DE MEDIDAS DE SEGURIDAD A PERSONAS CON PADECIMIENTO MENTAL}

Palabras clave: inimputabilidad, peligrosidad, medida de seguridad

El artículo 34 del Código Penal de la Nación versa que:

No son punibles:

$1^{\circ}$. El que no haya podido en el momento del hecho, ya sea por insuficiencia de sus facultades, por alteraciones morbosas de las mismas o por su estado de inconciencia, error o ignorancia de hecho no imputables, comprender la criminalidad del acto o dirigir sus acciones.

En caso de enajenación, el tribunal podrá ordenar la reclusión del agente en un manicomio, del que no saldrá sino por resolución judicial, con audiencia del ministerio público y previo dictamen de peritos que declaren desaparecido el peligro de que el enfermo se dañe a sí mismo o a los demás.

En los demás casos en que se absolviere a un procesado por las causales del presente inciso, el tribunal ordenará la reclusión del mismo en un establecimiento adecuado hasta que se comprobase la desaparición de las condiciones que le hicieren peligroso.

En este artículo del código, se plantea como medida para el "tratamiento" de aquellas personas con padecimiento mental que han cometido una acción antijurídica, las medidas de seguridad. Éstas, teniendo en cuenta que al sujeto se lo ha declarado "inimputable", es decir que no se le puede punir (penar) por el hecho cometido, se toman bajo la presunción de peligrosidad del sujeto, y la medida se extiende "hasta que se comprobase la desaparición de las condiciones que le hicieren peligroso".

Cuando una persona es declarada inimputable, esa declaración se hace previo a iniciar el proceso judicial por el que podrían encontrarla culpable o 
inocente de la acción de la que se la acusa, indicando que el sujeto es irresponsable, pero aplicándosele una medida de seguridad, lo cual resulta anticonstitucional, dado que se le aplica a la persona una pena, pero sin culpabilidad, es decir, sin delito. Podría en algunos casos, incluso, convertirse en doblemente inconstitucional: por ausencia de culpabilidad y por no demostrarse si el sujeto cometió efectivamente el injusto que se le adjudica, lo que implica la posibilidad de que no lo hubiese realizado, pero, no obstante, se le aplica la medida de seguridad.

\section{Sobre el concepto de "peligrosidad" en el derecho}

El filósofo alemán Ludwig Andreas Feuerbach ${ }^{\text {xxiv }}$ en 1799 fue el primero en acuñar el término. Conceptualizó el peligro como un principio subjetivo y una probabilidad "la cualidad de una persona que hace presumir fundadamente que violará el derecho" (Ruiz-Funes, 2011, p.1125), donde la fórmula "violará el derecho" implica una seguridad.

Pero la "peligrosidad" hace su entrada fuerte en la criminología en el momento de auge del positivismo criminológico italiano (período descripto en un apartado precedente): Enrico Ferri identifica el peligro con la conducta criminal, afirmando que todos los delincuentes son peligrosos, por el solo hecho de haber delinquido. De esta forma, el peligro se define por la circunstancia de haber cometido o intentado cometer un delito y se asienta EN el sujeto.

En línea con el planteo de Ferri, Ludovico Mortara en 1920, concibe a la peligrosidad como "el grado de ofensa que sufren las leyes de la convivencia social por un hecho delictivo" (Ruiz-Funes, 2011, p.1126) agregando que no se mide por la imputabilidad, sino por la temibilidad y peligrosidad del autor.

En 1887 se inicia en la Argentina el período más importante en donde el positivismo criminológico italiano se inserta en la academia, de la mano de Norberto Piñero en la Universidad de Buenos Aires. 
Con la asunción de la doctrina positivista, se instaura también el paradigma de la peligrosidad, sobre todo luego de la inmigración de comienzos del siglo XX, donde la defensa social en Argentina cobra gran relevancia. En este contexto, el derecho penal y su concomitante política criminal, comienza a adoptar medidas más represivas ya que se considera que el sujeto peligroso no sólo atenta contra el orden social actual, sino que puede repetir sus conductas peligrosas en cualquier momento de su vida futura.

También por esta época es que se comienza con la necesidad de recluir al "loco peligroso", por ejemplo, en el proyecto de Código Penal de 1891, que presenta un artículo, el 59 que plantea que

(...) está exento de responsabilidad criminal quien haya cometido el hecho bajo la influencia de una alienación o de cualquier enfermedad mental (forma amplia en la que, según lo afirmado por la propia comisión en la "exposición de motivos", deben comprenderse "todas las enajenaciones mentales, afectivas, volitivas e intelectuales"). También lo está quien haya resuelto y ejecutado el hecho en estado de completa embriaguez sobrevenida accidentalmente (sin culpa); quien lo haya ejecutado en virtud de una sugestión hipnótica para la que no ha prestado su consentimiento; y quien sea menor de 14 años (el artículo continúa enumerando las causas de justificación del delito). (Creazzo, G. (2007). Pág. 64-65)

En estos casos, si el delito cometido por el enajenado prevé una pena alta -incluida la pena de muerte-, se plantea la reclusión en un manicomio hasta tanto haya desaparecido el peligro que motivó el encierro. Si, por el contrario, la pena que le cabría por la acción cometida fuese menor, el sujeto debe quedar en libertad bajo custodia; si no hubiese garantía de su custodia, entonces será recluido en manicomio. De esto se desprende lo que plantea Creazzo (2007):

(...) en el proyecto de 1891 la internación del "loco peligroso" está subordinada a un pronóstico sobre su estado mental basado en un criterio objetivo relativo, en la entidad de la sanción prevista para el hecho 
realizado y -de modo subordinado- en el "contexto social", o sea en la posibilidad efectiva de control extra-institucional sobre el propio sujeto (pág. 65-66).

Si algo despertó la inmigración de posguerra, fue un peligrosismo ligado al racismo. Así como antiguamente se pensaba al gaucho como el peligroso del que había que cuidarse porque era el representante de la mezcla de culturas, generándose esta contraposición entre civilización/barbarie; con el advenimiento de grandes masas de población europea, relegada o perseguida en sus países de origen, el gaucho no resulta tan peligroso, sino que el orden social se ve atentado por la figura del inmigrante. Se introduce la noción de "moral", para distinguir lo criminógeno y peligroso de lo civilizado: la pobreza, la falta de educación se consideran peligrosas y potencialmente criminógenas por ser "desfavorables a la moral".

De este modo, a comienzos del siglo $\mathrm{XX}$, con el auge del positivismo criminológico, se empieza a equiparar la criminalidad con la anormalidad, sobre todo con la figura de José Ingenieros ${ }^{\mathrm{xxv}}$, fundando una política criminal a partir de la peligrosidad del agente. Se trata de un enfoque psicopatológico de la criminalidad, donde se corre el foco del delito para centrarse de lleno en el delincuente, o en el peligroso -potencial delincuente-.

En la actualidad puede afirmarse que, si bien la postura peligrosista ha tenido sus críticas y detractores -sobre todo a partir de la década de 1940-, lo cierto es que, en las prácticas, sigue imperando el positivismo criminológico italiano en el Sistema Penal argentino.

¿Qué relación puede establecerse entre el concepto de "peligrosidad" y la medida de seguridad desde el Derecho?

El criminólogo José Ingenieros, al presentar la dicotomía entre civilización y anormalidad, pone el foco en el sujeto y no en el delito. De este modo, la premisa peligrosista se asienta sobre un individuo que "es" peligroso para el orden social y se plantea que la peligrosidad cesa una vez que aquello que lo 
ha convertido en peligroso, desaparece. Pero al asentarse en una concepción naturalista del sujeto -condicionado por la biología-, no queda más que sostener que el mismo es básicamente irrecuperable, podrá atemperarse su peligrosidad pero no desaparecer, dado que es connatural. De este modo, para defender a la sociedad, surgen dos posibilidades: la reeducación y la eliminación, premisas que van a guiar la reforma penitenciaria. La medida de seguridad aparece como un instrumento de defensa social, para separar de la comunidad al peligroso, sin un plazo prefijado, dado que no se sabe de antemano cuándo cesará su peligrosidad. Cabe incluso la posibilidad de que la segregación no tenga límite (transformándose el encierro en una forma de eliminación, dado que el sujeto no retorna nunca a lo social).

Sebastián Soler (1929), en su libro "Exposición y crítica de la teoría del estado peligroso", realiza un recorrido histórico del uso de la categoría "peligrosidad" en nuestro país, retomando a autores clásicos del positivismo, como Ferri y Garófalo. Va a analizar críticamente cada uno de los postulados que presentan $\mathrm{y}$, sobre todo, la aplicación práctica de la categoría de peligrosidad, por considerar que en su utilización en los casos de medidas de seguridad aplicadas en forma anticipatoria a un hecho -es decir, antes de que el sujeto cometa un delito-, lo que se hace es ir contra derecho. El autor detecta que, bajo esa categoría, entran al menos dos tipos de personas: aquellas que han cometido una serie de acciones que pueden considerarse delitos por el Código Penal, convirtiéndose de ese modo en peligrosos, y aquellos que no han cometido ningún hecho, pero que reúnen ciertas características que podrían hacerlos proclives a actuar de determinada manera. Lo que sostiene Soler es que, en ambos casos, lo que está primando es una premisa anticipatoria, o bien porque el sujeto ya ha delinquido y por lo tanto tendría predisposición al delito, o bien por portar ciertas características particulares -que bien pueden ser biológicas, de carácter o fenotípicas-.

Otro autor que aborda la premisa anticipatoria es Vicente Carrara (2011), quien diferencia el daño potencial del peligro. Su idea en torno al daño potencial es la siguiente: "Cuando no sobreviene la pérdida completa del bien 
atacado, existe sólo en el resultado del acto externo la potencia necesaria para producirla, pero no ha llegado a ser completa la violación del derecho" (pág. 1125).

Ruiz-Funes (2011) plantea que el peligro implica una conducta futura en relación con un delito que ya ha sobrevenido o con otra conducta que ya existe. El peligro implica un pasado, un presente y un futuro, una conducta pretérita, una conducta actual y una conducta venidera.

Lo que importa es determinar la función de lo posible y lo probable en el concepto de peligro porque así planteado, el peligro es la posibilidad y probabilidad. Lo posible es expectativa de conducta; lo probable, pronóstico de conducta, es lo verosímil; lo que es lógico que suceda, aunque no llegue a ocurrir.

De Benedetti (1938), en el Primer Congreso Latinoamericano de Criminología en 1938, sostuvo que la posibilidad es un juicio abstracto, en el que prescinde de las características de un sujeto determinado; y la probabilidad, un juicio sobre las circunstancias concretas de una persona o de ciertos actos. El peligro no es sólo y necesariamente un juicio, sino también un estado. Es este último elemento el que, asociado a la probabilidad, engendra el juicio. La operación mental que sirve de base al juicio de peligro se funda indudablemente en la idea sugerida por la situación del sujeto y en las relaciones que la misma autoriza a suponer como verosímiles, es decir, en las relaciones probables entre la manera de ser y una determinada conducta futura. Es un juicio subjetivo.

El peligro es sobre todo la situación de una persona y los modos de ser y de actuar sucesivos que es verosímil desprender de ella en función de los cambios probables que hayan de influir sobre sus condiciones de vida. El peligro es el estado y la probabilidad.

Patricia Ziffer (2006) analiza cómo en la concepción de peligrosidad, predomina la perspectiva de la predicción a futuro, que lleva a tomar como decisivo para calificar a alguien como "peligroso" no lo que hace o hizo sino lo 
que se sospecha que hará por el sólo hecho de presentar ciertas características individuales. En este sentido, la autora sostiene que, a la hora de tomar una decisión basada en la peligrosidad de un sujeto, el juicio de valor que se realiza es subjetivo, y el derecho, generalmente, se jacta de ser objetivo: la aplicación de la ley tal cual lo indica el Código.

También en el "Fallo Gramajo SCJN sobre Inconstitucionalidad del art. 52", se hace referencia al hecho de que cuando se toma a la peligrosidad como pronóstico de conducta, esta caracterización es siempre injusta o irracional por su carácter de probabilidad, de predicción, lo cual carece de cualquier base científica, quedándose en lo meramente empírico.

En este fallo se va a discutir acerca de las medidas de seguridad, las cuales se apoyan en la "peligrosidad": lo que prima en la misma no son los delitos ya cometidos por el sujeto, sino los que podría llegar a cometer (porque es peligroso, tiende al delito, sus antecedentes lo demuestran). Termina siendo una medida predictiva que tampoco es atinente al Código Penal. También se hace referencia en dicho fallo a la acientificidad de ese aspecto de la noción de "peligrosidad", en tanto si se hace un estudio científico y se llega a la conclusión de que la peligrosidad existe, nunca se podría decir en qué sujetos ni en qué momento se pondría de manifiesto, por lo que no es posible evaluar ni comprobar científicamente la peligrosidad en un sujeto.

Se plantea como "peligroso" el hecho de poner una medida de seguridad de encierro por tiempo ilimitado, hace dudoso el saber cuándo terminaría la misma y cuáles serían las causales que la harían cesar. En este sentido, se puede pensar que en realidad el hecho de que sea ilimitada y no se pueda saber con anticipación cuándo cesaría la medida de seguridad, es consecuente con la decisión de su aplicación: si no se puede establecer ni definir qué es la peligrosidad, ¿cómo se va a poder determinar cuándo cesa? Tampoco se puede definir si es un estado pasajero del sujeto o si es connatural al mismo y siempre va a ser peligroso. 
La utilización de la concepción de "peligrosidad", deja en claro que lo que se busca es la protección de la sociedad; cuando lo que se aplica es una medida de seguridad, que lejos de ser curativa es de reclusión, se protege a la sociedad de este sujeto peligroso -porque se lo aísla-, pero nadie protege a este sujeto que ha sido puesto bajo tutela del estado. Se deja de lado la posibilidad de tratamiento en pos de un castigo.

Se postula en el fallo también, que las medidas de seguridad, en la mayoría de los casos, se cumplen en penales y no en instituciones de salud, con esto se equipara a quien supuestamente debiera ser cuidado o curado en su salud con quien ha cometido un delito y es encontrado culpable, no hay diferenciación en el "tratamiento". De este modo, se sostiene que las medidas de seguridad terminan siendo penas en sí mismas. Lo que las diferencia de estas últimas, es que no tienen un plazo predeterminado -lo cual las convierte en algo peor que una pena, dado que cuando un sujeto resulta penado, sabe en qué momento termina su condena y retorna a la libertad-, pero en el cumplimiento efectivo de las mismas, tanto en los espacios como en los tratamientos, ambas son equiparables.

En el fallo se trasluce la responsabilidad del Estado cuando decide considerar a un sujeto o bien como culpable o bien como peligroso y las consecuencias de la consideración de peligrosidad de un individuo ante la posible aplicación de las medidas de seguridad por tiempo indeterminado, con las consecuencias antes mencionadas.

Así, el concepto de peligrosidad termina siendo un juicio subjetivo de valor de carácter arbitrario, tanto del abogado que lo presenta, como de los jueces que terminan fallando en consecuencia.

Al quedarse solamente en las características de personalidad del sujeto y plantear desde allí la peligrosidad de éste, no se está muy alejado de las concepciones lombrosianas: al ser el sujeto peligroso en sí mismo, su personalidad es inmodificable, por lo tanto, la medida de seguridad lógicamente 
debe ser ilimitada, se basa en la concepción de un determinismo bio-psicosocial del sujeto (Domínguez Lostaló, 1997).

¿Cómo se juega el concepto de peligrosidad en la especificidad del padecimiento mental?

Históricamente la "locura" ha ido ligada a la noción de peligrosidad. R. Zaffaroni (2009) sostiene que esto se da, sobre todo, porque las personas que tienen un padecimiento mental no comparten los valores de los sectores hegemónicos, no son funcionales a los mismos.

Vicente Cabello (1963, p. 876-882), psiquiatra forense, plantea una fórmula de cinco elementos para diagnosticar la peligrosidad en personas con padecimiento mental:

1) Personalidad del autor. Constituye la llave maestra del diagnóstico: imprime a los signos toda su modalidad, mide y dirige las reacciones, orienta la conducta y guarda reservado el porvenir.

2) Naturaleza y carácter de la enfermedad que padece. Si bien no hay delitos específicos de una determinada psicosis, ésta marca generalmente una tendencia criminosa.

3) Su momento evolutivo. Existe un momento en la evolución de las dolencias mentales donde hace crisis la actividad delictuosa. El tratamiento favorece o acorta el período de peligrosidad.

4) La gravedad del delito. Proporciona un medio valioso para apreciar psiquiátricamente al enfermo.

5) Condiciones mesológicas relacionadas a la vida familiar y social del enfermo, proyectadas a su futura existencia. Según la disposición del ambiente al cual deba restituirse el insano pueden diferenciarse medios adversos, favorables y neutros. 
Resulta interesante retomar estos 5 puntos, en los cuales se puede vislumbrar la herencia de los preceptos del positivismo italiano de Garófalo.

Este mismo autor, en 1963, sostiene que la medida de seguridad no es retributiva como la pena, se fundamenta en la peligrosidad y no en la importancia del bien lesionado, atendiendo más a lo que la persona es que a lo que ha hecho. Basándose la medida de seguridad en una condición personal del individuo que ha de ser indeterminada, pues su duración depende del efecto educativo y curativo que haya experimentado aquel a quien se impone.

En este sentido, Ziffer (2006) será taxativa a la hora de sostener que si la premisa peligrosista se justifica en los casos en los que un sujeto es considerado peligroso porque ya ha delinquido con anterioridad, esto se debe a que en realidad, la cárcel no sirve como dispositivo "re-socializador", sino que el efecto que produce en el sujeto es el contrario, por lo que es el mismo Sistema Penal, en su aplicación, el que convierte en peligrosa a una persona. El "efecto curativo" no es tal.

La construcción del "loco peligroso" se reafirma y refuerza cuando la persona con padecimiento mental entra en conflicto con la ley penal.

Esto permite abrir la indagación acerca de qué sucede entonces cuando la persona que comete una acción antijurídica posee un padecimiento mental, ¿se lo considera un "loco" o un criminal? ¿Interno o paciente? Como bien expresa la Ley Nacional de Salud Mental N. ${ }^{\circ} 26.657$ (2011):

(...) Es importante asegurar la protección de la salud mental de todas las personas y el pleno goce de los Derechos Humanos de aquellas con padecimiento mental que se encuentran en el territorio nacional (Art. 1).

Pero en este contexto ¿qué pesa más? ¿la acción cometida? ¿la "peligrosidad" del sujeto que porta un padecimiento mental y que ha delinquido? ¿la persona con padecimiento mental? 
Cobra importancia en estos casos, la figura del perito psiquiatra, quien colaborará en la determinación de la responsabilidad jurídica de un sujeto frente a una acción cometida. Lo que se termina transformando en la mayoría de las veces en la emisión de un juicio sobre la capacidad del sujeto de delinquir, es decir, sobre su potencial de peligrosidad.

\section{De la locura al padecimiento mental}

A continuación, se realiza un recorrido histórico acerca del concepto de "locura", su transformación en "loco peligroso" y su superación con la noción de padecimiento mental. Esta historización, permite situar a la "locura" como una categoría producto de un contexto, a la cual es posible darle fecha de nacimiento. La consideración de la locura a la que se le anexa la cualidad de peligrosa también responde a ciertos parámetros propios de una época, pudiendo así plantearse que en definitiva los mismos resultan arbitrarios para considerar a una persona como "loco peligroso", ya que históricamente el tratamiento de la salud mental ha sido distinto.

En la actualidad puede afirmarse que, en lo jurídico, prima el paradigma humanista que intenta deslindar al sujeto del estereotipo del loco criminal, mediante un cambio de concepción que no reduce al individuo a su padecimiento. En el recorrido histórico que se plantea, podrá visualizarse cómo se ha ido dando ese cambio, con la particularidad de que, si bien en lo discursivo impera un paradigma que propone el respeto y garantía de los derechos de las personas con padecimiento mental, en las prácticas sigue resistiendo el positivismo. Puede decirse que asistimos a la convivencia de dos paradigmas.

En "Historia de la Locura en la época clásica", Foucault (2015) realiza un recorrido histórico del tratamiento de "la locura" en diferentes momentos, en los que relata el abordaje que se le da a esa categoría en cada uno. Sitúa que hasta principios de siglo XVII, la locura no tendrá una connotación negativa ni amenazante, sostiene que es un mundo "hospitalario para la locura". A partir de 
ese momento, surgen ideas de pensamiento provenientes de la filosofía, principalmente con Descartes, que empiezan a plantear el paradigma de la "sinrazón", precipitando el dispositivo de encierro como medida de tratamiento de "la locura", aunque no se precisara a ciencia cierta su estatuto, dado que bajo la misma modalidad de abordaje se encontraban los pobres, desocupados, los homeless y los insensatos.

Thomas Szasz (2005) plantea que, a partir del declive del poder de la Iglesia durante el siglo XVII, desaparece el binomio que se sostenía hasta el momento formado por bruja-inquisidor, para dar lugar al nuevo binomio: locoalienista. Explica que la definición de "locura" en ese momento, responde a las exigencias para la cual fue creada: un estado que justifique el encierro en un asilo. Éste se realizaba no para que las personas alojadas allí recibieran cuidados médicos, sino para proteger a la sociedad de estos desviados y para prevenir la desintegración de las instituciones sociales.

En los años 1600-1700, Foucault menciona la existencia del "Gran encierro" como el nacimiento de la institución en donde se alojaba indiscriminadamente a los locos, los criminales, las prostitutas y los vagabundos. En este período se construye e inaugura una gran cantidad de hospitales generales y hospicios al estilo de leprosarios. Contribuirá en esta tarea no sólo el Estado, sino también la Iglesia católica, que será quien tomará en su gran mayoría, la dirección de muchos de esos "centros de caridad" (pág. 84 y sig.).

A partir de la Revolución Francesa se separa en diferentes instituciones a estos grupos que quedan por fuera de lo social: instituciones psiquiátricas y prisiones, y posteriormente centros para menores de edad. Éstas tienen dos funciones por un lado el aislamiento y la exclusión (modelo de la lepra) y el control y la vigilancia por el otro (modelo de la peste). Esto se ve acrecentado luego de la Revolución Industrial, en donde con los movimientos sociales que se ocasionan, empiezan a surgir nuevas clases sociales y nuevos grupos problemáticos para el orden social. Dice Foucault (2015): 
La práctica del internamiento designa una nueva reacción a la miseria, un nuevo patetismo, más generalmente otra relación del hombre con lo que puede haber de inhumano en su existencia. El pobre, el miserable, el hombre que no puede responder de su propia existencia, en el curso del siglo XVI se ha vuelto una figura que la Edad Media no había reconocido (pág. 90 y sig.).

A partir del siglo XVII, el encierro será una respuesta a la pobreza que iba en crecimiento en los principales países europeos: el Estado se hará cargo de la manutención de esa porción de la población, pero en la internación, es decir que entraña la pérdida de la libertad. La locura ya no será tomada como una intercesión divina, sino que se convertirá en un aspecto molesto para los objetivos productores de las pujantes naciones industrializadas.

Esto se vuelve relevante cuando desde mediados de 1600 , se introduce en las casas de confinamiento y hospicios el trabajo como una "medida terapéutica", cuyo objetivo real consistía en que las personas que se encontraban privadas de su libertad contribuyeran a la idea capitalista y a cambio, recibían un poco de dinero por la labor realizada.

Paulatinamente la inclusión del trabajo en las instituciones de encierro empieza a desaparecer, haciendo que quienes se encontraban internados, ya no percibieran ningún tipo de ingreso económico para su manutención. Los hospicios se transforman en verdaderos leprosarios, espacios de ociosidad, que darán inicio, dice Foucault (2015), a la verdadera locura, la sinrazón:

En estos sitios de ociosidad maldita y condenada, en este espacio inventado por una sociedad que descubría en la ley del trabajo una trascendencia ética, es donde va a aparecer la locura, y a crecer pronto, hasta el extremo de anexárselos [...] El siglo XIX aceptará, e incluso exigirá, que se transfieran exclusivamente a los locos estas tierras, donde ciento cincuenta años antes se quiso reunir a los miserables, a los mendigos, los desocupados (pág. 115). 
Con el advenimiento del paradigma positivista, la psiquiatría institucional buscará las causas científicas de la locura en lo individual biológico, jugando un papel importante la relación con la peligrosidad y las clasificaciones: el loco es peligroso para sí o para terceros, es peligroso para el orden social, se lo equiparará con el criminal y esto lo convertirá en apto para la aplicación de sanciones, siendo la privilegiada el encierro. Es el surgimiento de la categoría del "loco peligroso", intersección entre salud mental y derecho.

Este paradigma se ve conmovido en el siglo XX a partir de la Declaración de los Derechos Humanos al entrar en crisis la ciencia y el naturalismo como respuesta absoluta y como único modo de lectura de la realidad. A partir de la década del ' 70 , comienzan a darse a nivel mundial, movimientos impulsados por la antipsiquiatría y la desmanicomialización, siendo la reforma del neuropsiquiátrico de Trieste, impulsada por Franco Basaglia, el ejemplo más claro de ello (ley 180/1978).

En el año 1991, las Naciones Unidas elaboran los Principios para la Protección de los Enfermos Mentales y para el Mejoramiento de la Atención de Salud Mental, adoptada por la Asamblea General en su resolución 46/119, una normativa internacional que introduce modificaciones sustantivas a la hora de pensar al padecimiento mental. Ya no primará la peligrosidad como criterio para el tratamiento o el encierro de una persona, sino el concepto de salud.

Argentina cuenta con la ley nacional de salud mental N.$^{\circ} 26.657$ desde diciembre de 2010, pero las discusiones respecto a la necesidad de una legislación en la temática, comenzaron mucho antes, en la década de 1950, sólo que el proceso se vio dificultado e interrumpido por la sucesión de gobiernos de facto que se convertían en terreno infértil para el avance en materia de salud mental por las persecuciones y desapariciones a las que se vieron sometidos muchos profesionales y estudiantes del área.

La primera definición fuerte que presenta la ley de salud mental es la de salud, la cual es entendida como un proceso y no como clásicamente se la había planteado, como un estado. El comprender a la salud como un proceso, 
implica retirarle al padecimiento su carácter de inmodificable, lo quita del ser del sujeto. Así entendido, el padecimiento mental es una situación transitoria que además deberá estudiarse y diagnosticarse a partir de una multiplicidad de variables entre las cuales la biología de la persona será una más y no la determinante (debe atenderse a la historicidad, lo vincular, cultural, social, situación económica, momento político, etc.). Así, se considera a la salud como un proceso de determinación múltiple, y al sujeto como integral.

La ley hace énfasis en la perspectiva de Derechos, sobre todo con relación a la protección de las personas usuarias de los servicios de salud mental. Se introduce la nominación de "persona con padecimiento mental"xxvi, para hacer hincapié sobre la persona y no sobre el padecimiento (enfermo mental, esquizofrénico, psicótico, etc.) y favorecer la no discriminación y la desestigmatización.

La ley prohíbe la creación de nuevos hospitales monovalentes, públicos o privados (art. 27). Los existentes deben adecuar sus servicios a este nuevo paradigma. Se establece así un proceso de desmanicomialización y desinstitucionalización de la atención y tratamientos, que tiene como horizonte temporal el año 2020, tal como lo estipula el Consenso de Panamá de la OPS/OMS del año 2010.

De esta manera, se deben reestructurar los Servicios de Salud Mental para que tengan como eje la comunidad y no el hospital (enfoque hospitalocéntrico), sin que ello implique reducción de personal o de sus derechos.

Se debe tender al mantenimiento de los vínculos comunitarios, familiares o referentes afectivos, laborales y no su restricción. Es decir, se debe promover la inclusión socio-comunitaria y no la exclusión que implica la internación. Debiendo para esto adoptarse modalidades de abordaje interdisciplinarias e intersectoriales basadas en los principios de la Atención Primaria de la Salud (art. 9). Esta idea se sostiene en que el ser humano solo puede desarrollarse plenamente en la comunidad (art. 29 de la Declaración Universal de Derechos). 
Como forma de combatir la lógica manicomial de la atención de la salud mental, las internaciones referidas al área deben atenderse en hospitales generales (art. 28), siendo un acto de discriminación no hacerlo y que es sancionado por la ley N. 23.592 (antidiscriminatoria). Esto alcanza a las internaciones vinculadas a consumos problemáticos de sustancias (Art.4).

La internación debe considerarse un recurso terapéutico de carácter restrictivo, y debe ser empleada cuando se hayan agotado otras medidas terapéuticas realizadas en el ámbito familiar, comunitario y social (art. 14). La misma debe darse cerca de la comunidad de origen del sujeto y debe ser lo más breve posible, para evitar la ruptura de vínculos comunitarios y familiares.

Existen dos tipos de internación: la voluntaria (art.18) y la involuntaria (art. 20). La primera es cuando la persona decide acudir a un servicio de salud mental para solicitar internarse, la que debe ser informada al juzgado si se prolonga más de 60 días. El juez interviniente deberá decir en un plazo de 5 días si autoriza la continuidad de la medida.

La segunda solo es procedente cuando a criterio del equipo de salud mediare situación de riesgo cierto e inminente para sí o para terceros que amenace o cause perjuicio a la vida o integridad física de la persona y/o de otras. Ese riesgo debe ser verdadero, seguro e indubitable no reduciéndose a una clasificación diagnóstica o psicopatológica.

La ley no menciona la situación de las personas con padecimiento mental que se encuentran encerradas bajo medida de seguridad en instituciones penitenciarias, pero desde el derecho, cuando acontece una situación de acción antijurídica cometida por un sujeto que es considerado inimputable, lo que debiera primar es abordarlo desde la ley de salud mental. 


\section{LA CONSTRUCCIÓN DE LA FIGURA DEL “LOCO PELIGROSO” EN EL SEGUIMIENTO DE UNA NOTICIA PUBLICADA POR EL DIARIO EL DÍA DE \\ LA PLATA (Y PUBLICACIONES POSTERIORES REALIZADAS POR EL DIARIO HOY)}

Palabras clave: “Loco Peligroso", medios de comunicación, imaginarios.

Los medios de comunicación, se ha dicho, influyen en las subjetividades de las personas, construyen y reproducen imaginarios que se implantan de tal modo que les hace repetir esos mitos a modo de ensalmos y profecías autocumplidas, con su concomitante repercusión y efectos en aquel que es indicado como el "delincuente". En el caso de sujetos con padecimiento mental que cometen una acción que puede ser considerada antijurídica, la etiqueta de "peligroso" que precede a la figura del "loco", cobra especial fuerza y sirve, muchas veces, para justificar la aplicación de medidas de seguridad punitivas, antes que un abordaje terapéutico acorde con su situación de salud mental.

Esto tiene que ver con que la criminología mediática posee influencia sobre la política argentina y sobre el sistema jurídico-penal que lo que hace es "amoldarse" o responder en forma adaptativa a la "opinión pública" estructurada mediáticamente, intentando evitar crisis que impacten en la gobernabilidad o la capacidad de gestión (Villarruel, 2014. Pág. 101).

Nicolás, un joven de 26 años que vive en la localidad de Berissoxvii, se convierte en noticia una mañana de septiembre de 2016 cuando sale por las calles de su ciudad y acuchilla a cuatro personas en la vía pública.

El caso estuvo presente en el Diario "El Día" entre el 2 (versión digital) y el 8 de septiembre de ese año, reapareciendo recién el 2 de noviembre de 2018.

A continuación, se realiza un análisis del tratamiento mediático de esta situación, en el que se tienen en cuenta el discurso del medio, las imágenes que se seleccionaron para graficar la situación y el posterior seguimiento del 
destino del sujeto indicado como el responsable de estas "imágenes de terror en Berisso".

La primera mención que hace el diario El Día al respecto es en su formato digital del día 2 de septiembre, a las 11.52 de la mañana ${ }^{\text {xxviii: }}$

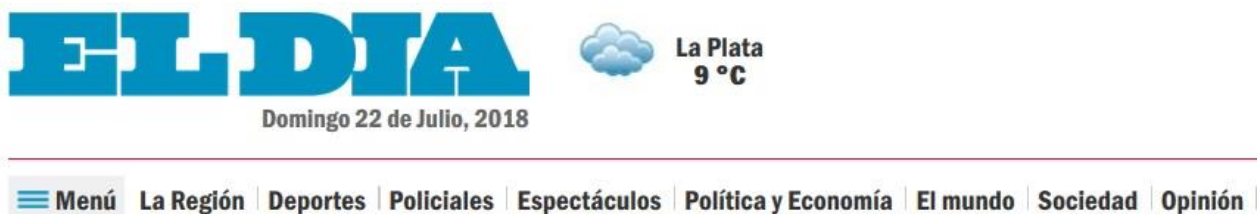

\section{POLICIALES}

\section{Imágenes de terror en Berisso: apuñaló a 4 personas en plena calle}

Ocurrió esta mañana en 9 entre 163 y 164. Las víctimas son un jubilado, una mujer, un joven y un taxista. El agresor fue detenido

2 de Septiembre de 2016 | 11:52

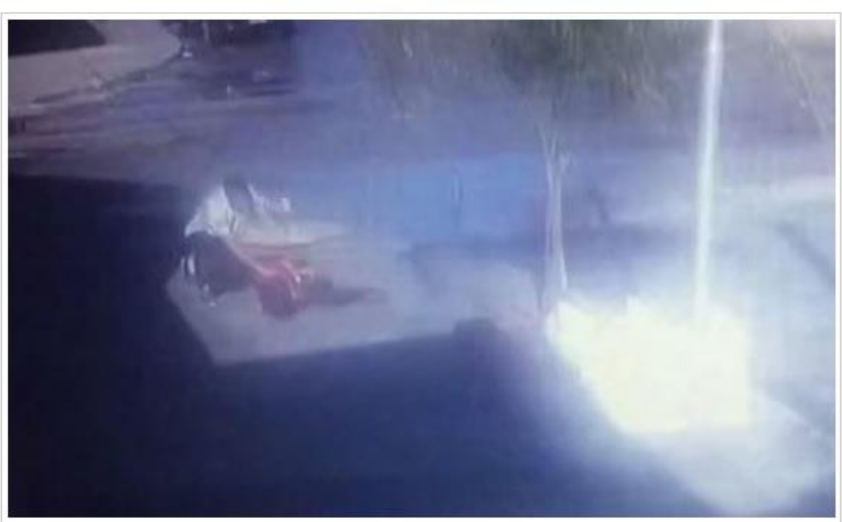

IMÁGENES DE TERROR EN BERISSO: APUÑALÓ A 4 PERSONAS EN PLENA CALLE 


\begin{abstract}
Un hombre de 26 años causó el terror esta mañana en las cercanías del centro berissense cuando, "sin mediar palabra" apuñaló a un hombre de unos 80 años y luego a tres personas más, entre ellas a una mujer que intentó detenerlo.
\end{abstract}

El hecho, que ocurrió cerca de las 1ohs en 9 entre 163 y 164, fue grabado por las cámaras de seguridad de un kiosco, donde clientes y empleados quedaron conmocionados por la violenta situación.

Ezequiel, dueño del comercio, relató en exclusiva a eldia.com lo sucedido:

"Era un día normal, estaba trabajando en el negocio y la gente que estaba adentro ve que una persona andando en bicicleta se tira arriba de un hombre mayor y lo empieza a apuñalar", dijo el joven.

Según los testigos, el agresor "no lo quiso robar, directamente lo atacó sin mediar palabra".

Segundos después, "una señora que tiene una panadería en la cuadra le gritó algo y el tipo se le tiró encima" asestándole "unas cinco puñaladas".

Siguiendo lo referido por Ezequiel, "como vio que nadie lo había visto se fue corriendo unos 50 metros para el lado de Montevideo, pero después volvió para apuñalarla 10 o 15 veces más por todos lados”.

Sin embargo, quien sí advirtió lo que pasaba fue un taxista que circulaba por el lugar, quien "le dijo algo" al atacante.

"Le tocó bocina y le gritó, entonces este tipo se tiró sobre el auto y lo apunaló por la ventana", todo mientras el vehículo "estaba en movimiento".

Lejos de culminar la faena dejando un tendal de tres personas heridas, el sujeto siguió buscando más víctimas. Y encontró una más: un joven que caminaba por ahí.

Mientras atacaba por cuarta vez a un inocente, el taxista herido alcanzó a comunicarse por el radio con sus compañeros, quienes acudieron en su ayuda.

"Un grupo de taxistas vino de todos lados y lo pararon en 9 y 164 hasta que llegó la Policía".

Finalmente el individuo fue detenido y se le secuestró un cuchillo de cocina "tipo de carnicero".

Todas sus víctimas trasladadas al hospital Larrain, donde se encuentran en este momento en estado de observación, si bien se estima que ninguno está grave.

\title{
Volanta: --
}

Título: Imágenes de terror en Berisso: apuñaló a 4 personas en plena calle

Bajada: Ocurrió esta mañana en 9 entre 163 y 164. Las víctimas son un jubilado, una mujer, un joven y un taxista. El agresor fue detenido.

Firma: no aparece autor del artículo.

Imágenes (fotos, dibujos, infografías): Fotografía de una cámara de seguridad de un kiosco, donde aparece el presunto joven atacando a una de las víctimas.

También se presentan dos videos que ya no se encuentran disponibles en la web, de uno de los testigos. 
Epígrafe: Imágenes de terror en Berisso: apuñaló a 4 personas en plena calle.

Destacado: Un hombre de 26 años causó el terror esta mañana en las cercanías del centro berissense cuando, "sin mediar palabra" apuñaló a un hombre de unos 80 años y luego a tres personas más, entre ellas a una mujer que intentó detenerlo.

El hecho, que ocurrió cerca de las 10.00, en 9 entre 163 y 164, fue grabado por las cámaras de seguridad de un kiosco, donde clientes y empleados quedaron conmocionados por la violenta situación.

\section{Subnotas:}

Tema que aborda el artículo: El ataque con un cuchillo de un joven a diferentes personas en la vía pública.

Breve análisis: En el título de la noticia lo que se encuentra es la espectacularización del caso a partir de las imágenes recuperadas de una cámara de seguridad de un kiosco, que es lo que permite titular como "imágenes de terror". Por otro lado, el término "apuñaló", en una lectura rápida y sin entrar en la nota, podría dar cuenta de un daño mayor infligido por parte del agresor en las víctimas, llegando incluso a poder pensarse en el fallecimiento de alguna de ellas, cuando en realidad de lo que se trató fue de lesiones superficiales en todos los casos.

El suceso ocurrió en un horario cercano a las 10 de la mañana y el diario ya lo tiene publicado a las 11.52 de ese mismo día, contando como fuente "oficial" a un testigo.

Lo que diferencia a este hecho de uno ligado a la inseguridad, es que quien es indicado como el agresor, actuó "sin mediar palabra" y "sin intenciones de robar", dando la impresión, por el relato del testigo, de una elección al azar de dos de sus víctimas (la primera y la última) y las otras dos siendo atacadas al intentar detenerlo.

La publicación cataloga de "faena" el accionar del agresor, dando así un tinte valorativo a la información, quitándole objetividad. 
El artículo culmina dando cuenta de la detención del sujeto y del traslado de las víctimas al hospital, en donde a esa hora ya se daba cuenta de que se encontraban todos fuera de peligro.

No se dan en esta publicación otros datos del sujeto más que su sexo y su edad, entre las fuentes consultadas sólo aparecen damnificados y algunos testigos, pero no se toma contacto con ninguna persona del entorno del detenido, por lo que la información que se da sobre él es parcializada.

Ese mismo día, en la página de la red social Facebook ${ }^{\text {xix }}$ que posee el diario El Día, realiza una publicación con enlace a la noticia en versión digital antes mencionada. Allí cambia el título, dando cuenta en el mismo de la detención del sujeto.

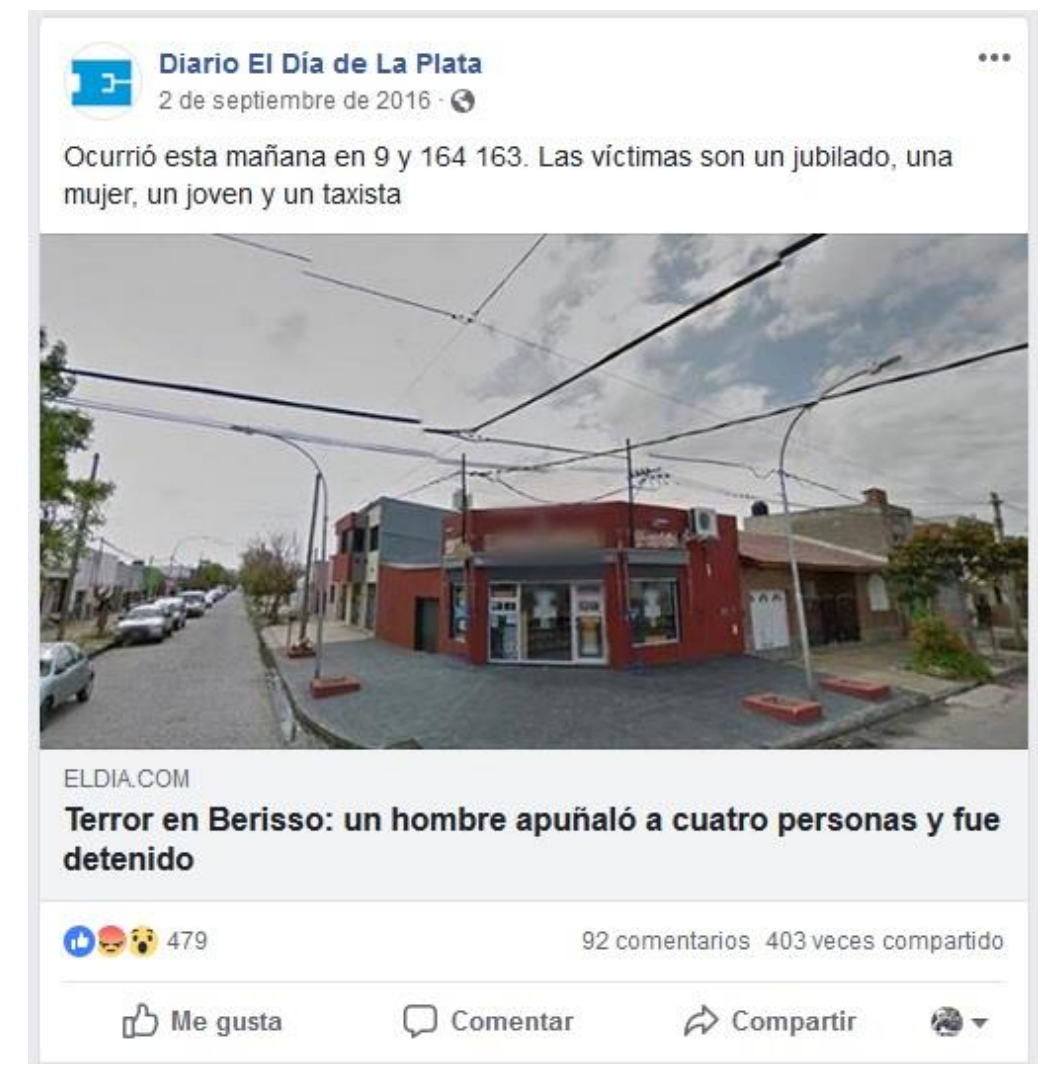

Volanta: Ocurrió esta mañana en 9 y 164 163. Las víctimas son un jubilado, una mujer, un joven y un taxista

Título: Terror en Berisso: un hombre apuñaló a cuatro personas y fue detenido 
Imágenes: foto de la esquina en la que ocurrieron los hechos y del kiosco que es mencionado en la nota periodística y del cual se tomaron las imágenes de video que fueron publicadas en la versión digital del diario.

Breve análisis: El título seleccionado para enlazar con la versión digital del diario, sostiene la historia del "terror" y utiliza también el verbo "apuñaló", introduce ya la información de la detención del agresor.

Es significativa la cantidad de veces que fue compartida la publicación por los usuarios de la red social (403 veces) y los comentarios que se han hecho (92), entre los cuales, en la gran mayoría lo que se hacía era solicitar el nombre de la persona, mayores datos escabrosos o morbosos de la situación, exigir encarcelamiento de por vida o pena de muerte, algunos haciendo referencia al temor frente a la figura del loco peligroso en las calles, y un comentario en particular que mostraba una imagen de un cuchillo ensangrentado, supuesta arma utilizada por el muchacho. La información personal del agresor aparece en los comentarios, aportada por particulares que se convierten en "corresponsales" del matutino.

Como sostiene Villarruel (2014) "Ocurre también que cuando un caso toma gran magnitud pública (...) la presión de los medios y de la opinión pública favorece que se salga a una caza de brujas" (pág. 31).

3 de septiembre de 2016, versión impresa del diario El Día.

Primera plana 


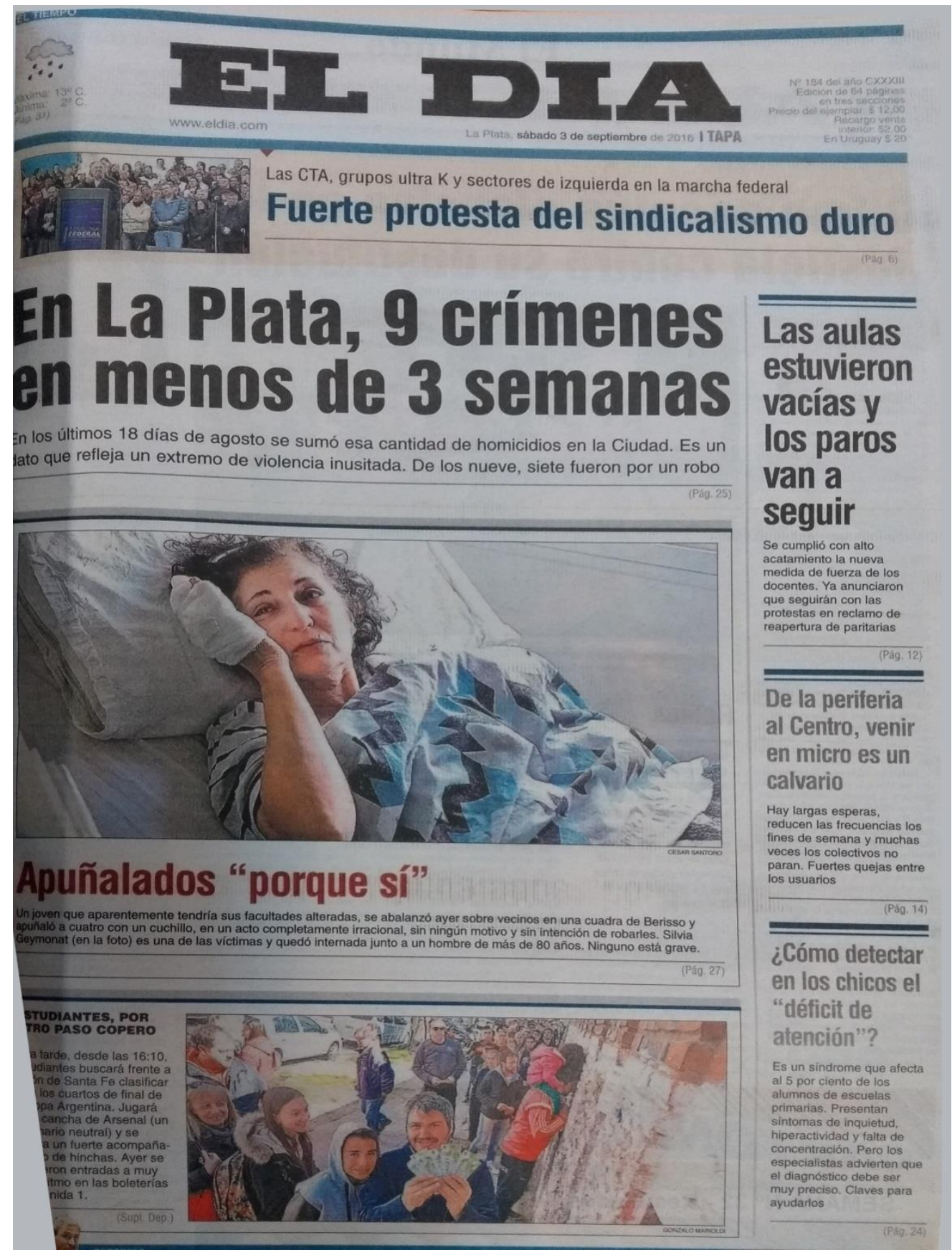




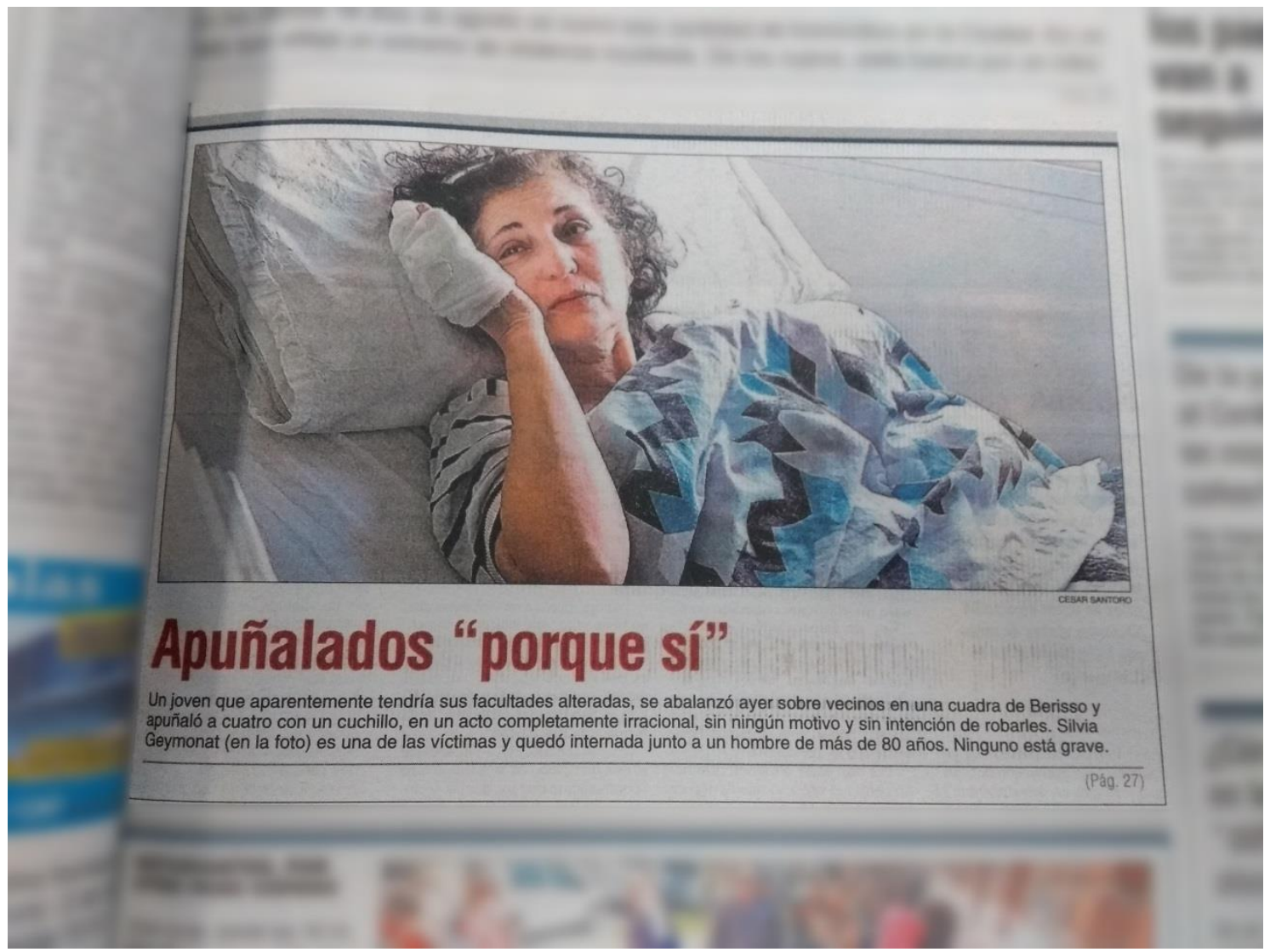

Diario: El Día

Fecha de edición: 3 de septiembre de 2016

Nota principal: La del caso en análisis

Tamaño que ocupa el artículo: un cuarto de página

\section{Volanta: ---}

Título: Apuñalados "porque si"

Bajada: Un joven que aparentemente tendría sus facultades alteradas, se abalanzó ayer sobre vecinos en una cuadra de Berisso y apuñaló a cuatro con un cuchillo, en un acto completamente irracional, sin ningún motivo y sin intención de robarles. Silvia Geymonart (en la foto) es una de las víctimas quedó internada junto a un hombre de más de 80 años. Ninguno está grave.

Firma: --- 
Continúa en página y/o sección: Continúa en página 27 (tercera página de la sección "policiales").

Imágenes: Foto grande a color de una de las víctimas, Silvia Geymonart, en una cama de hospital, mostrando sus vendajes (la misma foto o similar será publicada en todos los artículos que el Diario El Día difunda sobre el caso, a excepción del publicado el día 2 de noviembre de 2018).

\section{Epígrafe: ---}

Tema que aborda el artículo: sólo la presentación del caso, que se desarrolla luego en la página 27.

Es significativo que sobre la publicación que se tiene en análisis, aparezca otro titular que dice "En La Plata, 9 crímenes en menos de tres semanas" que contribuye a generar alarma previa a la lectura del titular "Apuñalados porque sí".

Tercera página de la sección policiales (página 27) 


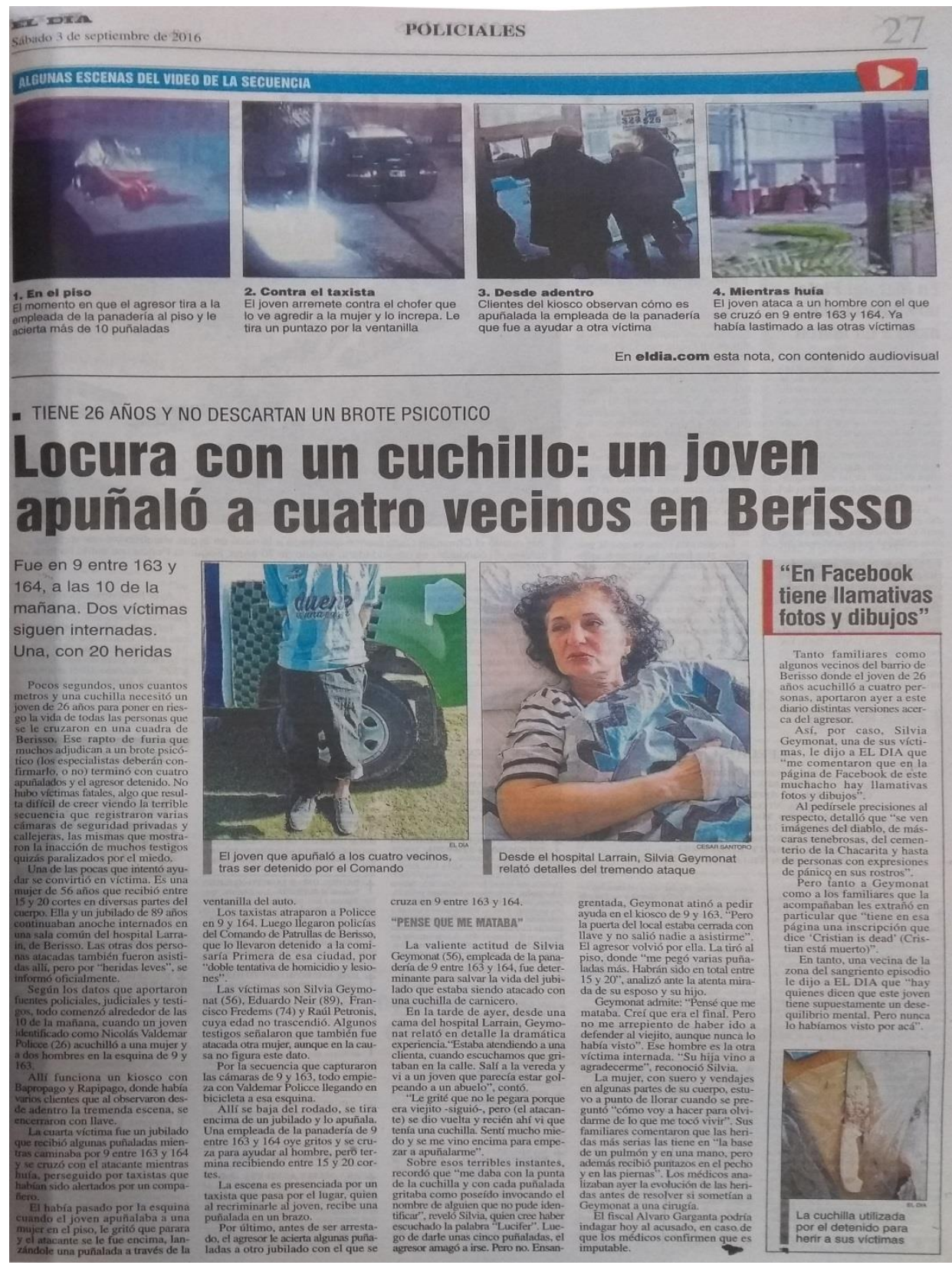

Nota principal: 


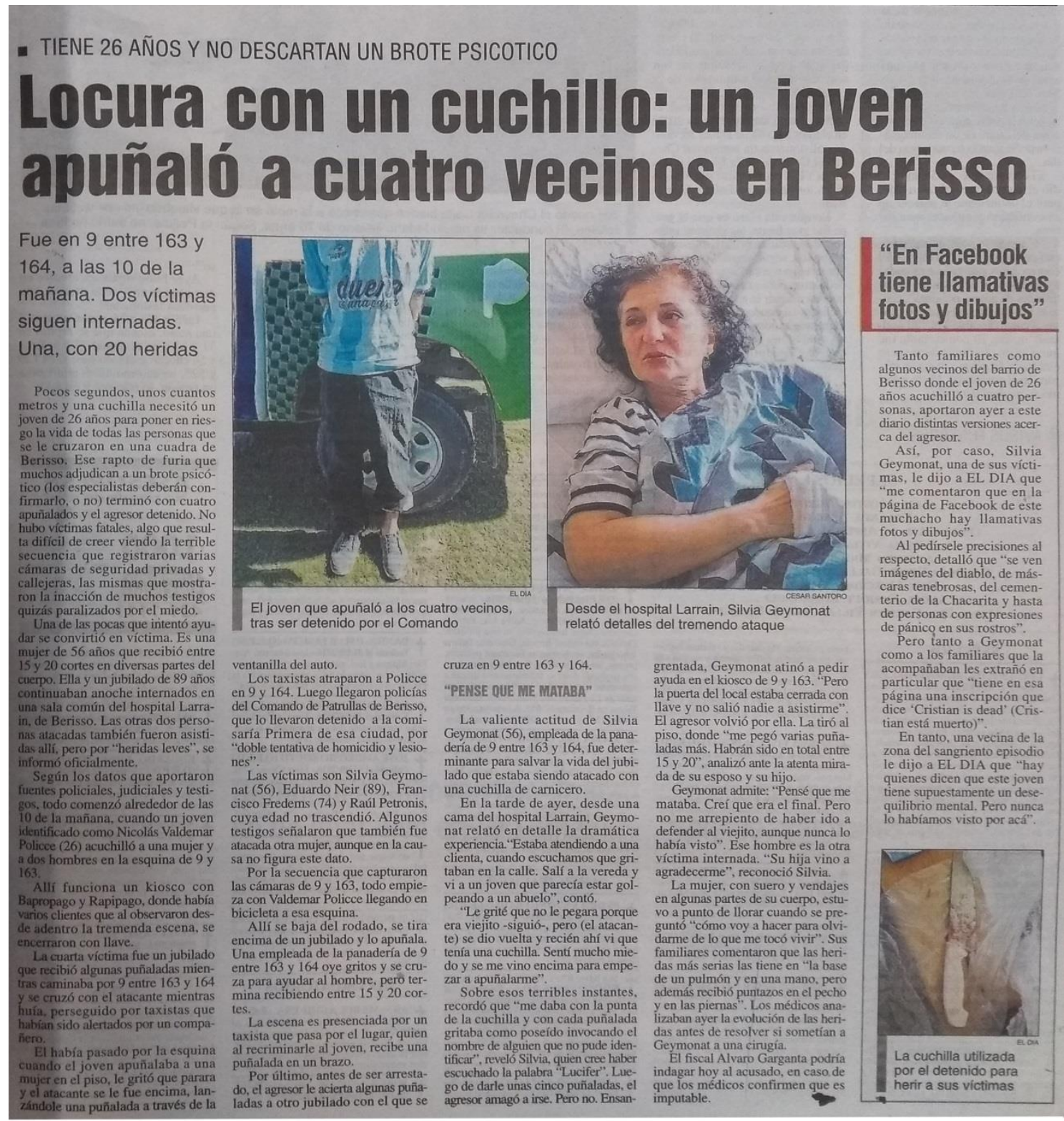

Diario: El Día

Fecha de edición: 3 de septiembre de 2016

\section{Nota principal}

Tamaño que ocupa el artículo: tres cuartos de página

Volanta: Tiene 26 años y no descartan un brote psicótico

Título: Locura con un cuchillo: un joven apuñaló a cuatro vecinos en Berisso 
Bajada: Fue en 9 entre 163 y 164 a las 10 de la mañana. Dos víctimas siguen internadas. Una, con 20 heridas.

Firma: ---

Imágenes: se presentan dos fotos a color, una de quien sería el agresor, que muestra del cuello hacia abajo, persona joven con ropa deportiva (camiseta de un club de fútbol), a la derecha de esa foto, la de Silvia, una de las víctimas, en la cama de hospital, exhibiendo sus vendajes.

Epígrafe: Foto 1: El joven que apuñaló a los cuatro vecinos, tras ser detenido por el Comando.

Foto 2: Desde el hospital Larrain, Silvia Geymonat relató detalles del tremendo ataque.

\section{Destacado: ----}

Subnotas: Se presentan dos "subnotas", una encima de la principal en donde puede observarse una secuencia de fotos. Otra a la derecha de la principal, que hace referencia a las redes sociales de quien sería el agresor.

Tema que aborda el artículo: Relata lo sucedido en la mañana del 2 de septiembre en la esquina de 9 y 163 de Berisso, desde el ataque del joven a cuatro personas (secuenciado) hasta su detención (con ayuda de un grupo de taxistas). Se mencionan fuentes policiales, judiciales y testimoniales (víctimas), aunque no se citan con nombre y apellido en todos los casos. Lo que más aparece en el desarrollo del artículo es información proveniente de las cámaras de seguridad y de una de las víctimas. En dichos de la empleada de panadería agredida, el sujeto habría gritado palabras difíciles de descifrar mientas la atacaba, entre lo que le pareció escuchar la palabra "Lucifer". El modo de titular la noticia es significativo, ya que nominan como "locura con un cuchillo" a la escena. El tema de la locura ("Palabras indescifrables", "Lucifer", "Facultades alteradas", "inimputabilidad") aparece en el artículo sin terminar de afirmarla, pero sentando posición desde el título. Incluso el título de la nota de tapa "Apuñalados porque sí, da cuenta de esta intencionalidad. 


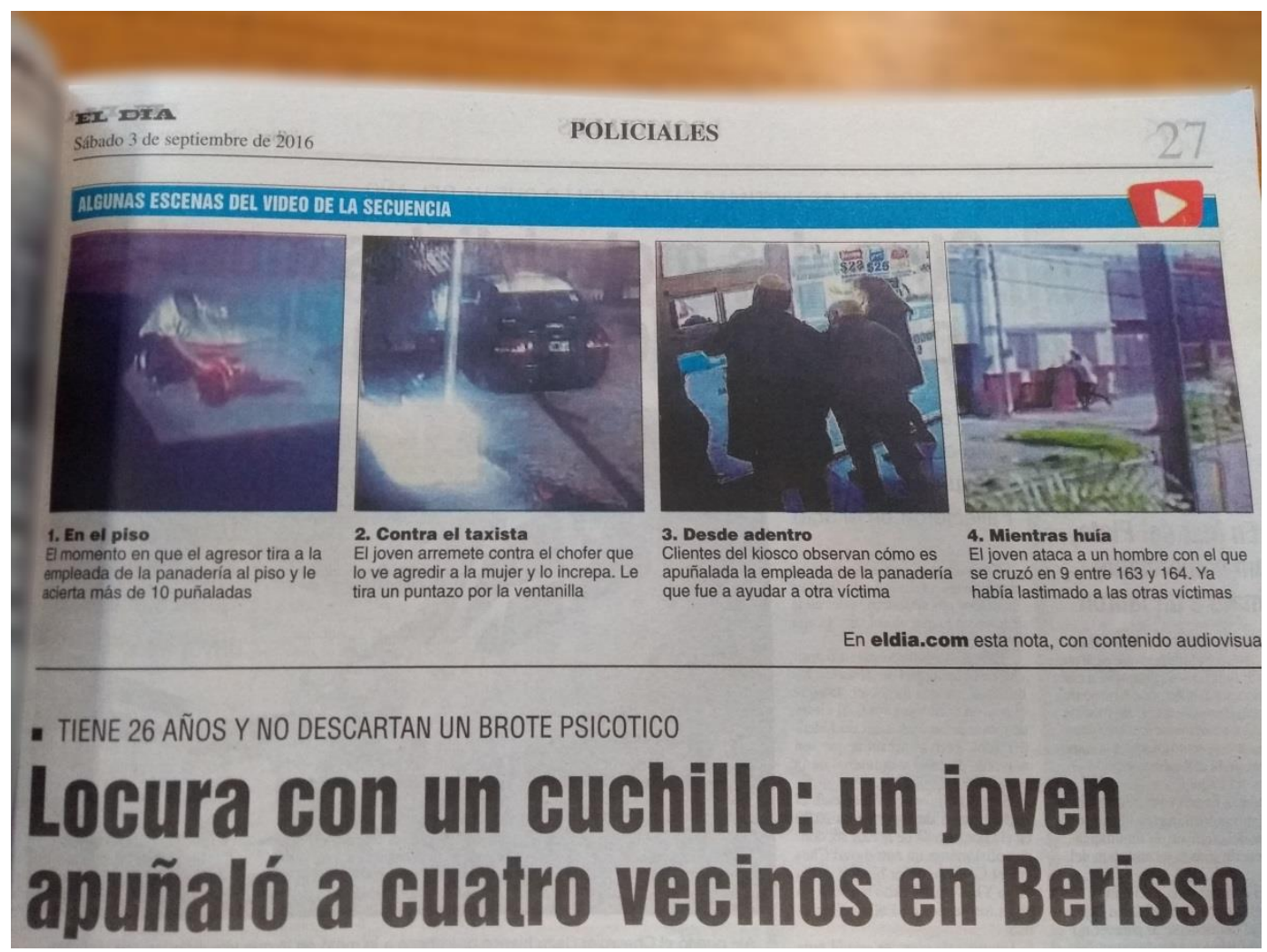

\section{Publicación secundaria.}

Tamaño que ocupa el artículo: un cuarto de página

Título: Algunas imágenes del video de la secuencia.

Imágenes: se presentan cuatro imágenes a color, dos de ellas del joven atacando a dos de las víctimas, una de esas fotos muy explícita, otra que muestra a vecinos dentro del kiosco y la cuarta del agresor presuntamente escapando, y atacando a la última de sus víctimas.

Epígrafe: Foto 1: En el piso. El momento en el que el agresor tira a la empleada de la panadería al piso y le acierta más de 10 puñaladas.

Foto 2: Contra el taxista. El joven arremete contra el chofer que lo ve agredir a la mujer y lo increpa. Le tira un puntazo por la ventanilla. 
Foto 3: Desde adentro. Clientes del kiosco observan cómo es apuñalada la empleada de la panadería que fue a ayudar a otra víctima.

Foto 4: Mientras huía: El joven ataca a un hombre con el que se cruzó en 9 entre 163 y 164. Ya había lastimado a las otras víctimas.

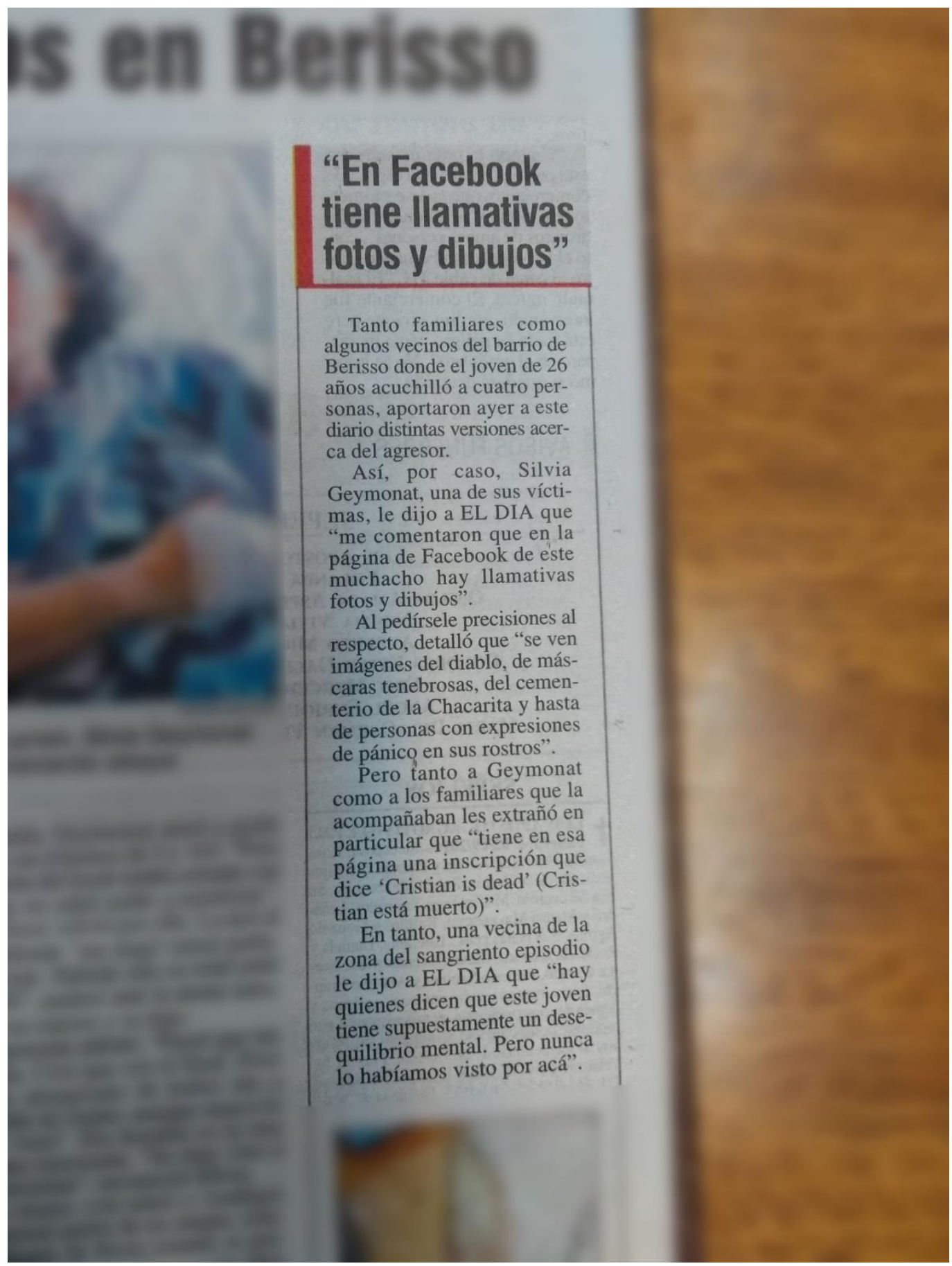




\section{Nota secundaria}

Tamaño que ocupa el artículo: un cuarto de página.

Título: "En Facebook tiene llamativas fotos y dibujos".

Imágenes: en la parte inferior de la nota, la foto de un cuchillo ensangrentado, a color.

Epígrafe: La cuchilla utilizada por el detenido para herir a sus víctimas.

Tema que aborda el artículo: brevemente relata versiones sobre el agresor, construidas en base a la visita en su perfil de Facebook y las imágenes que aparentemente se encontrarían allí. Esto lo aporta Silvia, una de las víctimas, que menciona que "le comentaron" que este joven tendría fotos y mensajes sobre muerte y perturbadoras en su red social; y los dichos de vecinos de la zona, que sostienen que aparentemente el joven tendría un desequilibrio mental, aunque nunca lo habían visto por el barrio. Es decir, ninguna fuente directa de información.

Todo lo que se aborda a lo largo de los diferentes artículos (central y secundarios) proviene de fuentes que privilegian la voz de las víctimas y las conjeturas, sin aportar certezas ni recurrir a la palabra de expertos o profesionales.

4 de septiembre en la versión digital de El Día, sale un nuevo artículo ${ }^{\mathrm{xxx}}$ 


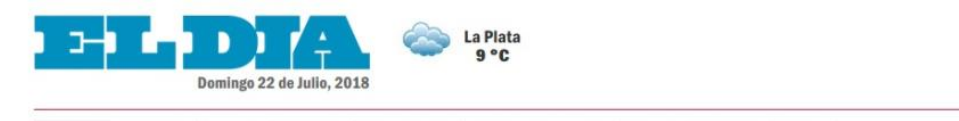

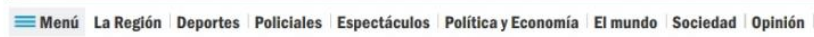

POLLCIALS

\section{Es inimputable el acuchillador de Berisso}

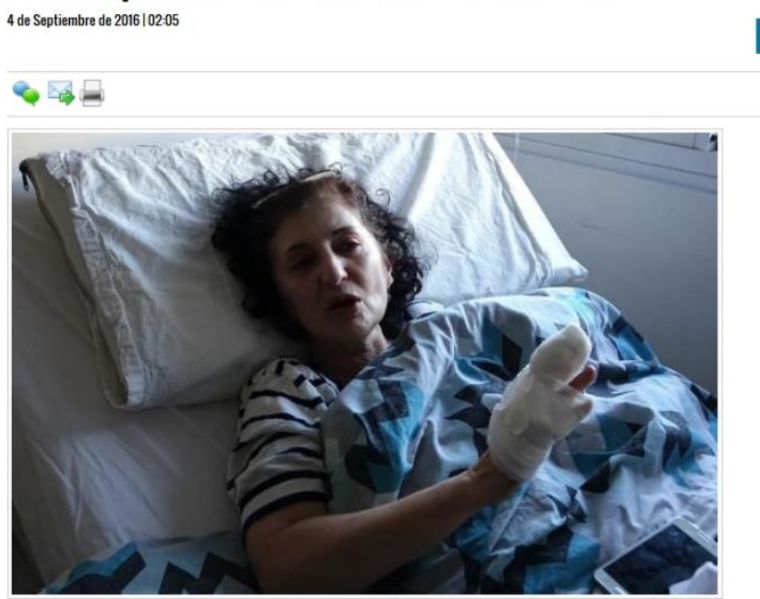

SILVIA GEYMONAT RECIBIÓ UNOS 20 CORTES AL SALR EN DEFENSA DE UN JUBILADO QUE ERA APUNALALADO POR EL AGRESOR, EN 9 Y 163

Nicolás Valdemar Policce (26), el joven que fue detenido el viernes por apuñalar a cuatro vecinos en Berisso, fue sometido ayer a una revisación médica, que lo declaró inimputable, no obstante lo cual mañana se le harán nuevos peritajes, informaron fuentes judiciales. En principio, no fue indagado y evalúan su traslado a una unidad neuropsiquiátrica.

Mientras tanto, siguen internados en el hospital Larrain Silvia Geymonat (56) y Eduardo Neir (89), dos de las víctimas que fueron atacadas el viernes a la mañana en la esquina de 9 y 163 . Las otras dos fueron Francisco Fredems (74) y Raúl Petronis, quienes recibieron heridas superficiales.

Por la secuencia que capturaron cámaras de un kiosco de 9 y 163, todo empezó con Valdemar Policce llegando en una bicicleta a esa esquina.

Se bajó del rodado, se tiró encima de un jubilado y lo apunaló. Geymonat, empleada de la panadería de 9 entre 163 y 164, escuchó los gritos y cruzó para ayudar al hombre, pero terminó recibiendo entre 15 y 20 cortes.

La escena fue presenciada por un taxista que pasó por el lugar, quien al recriminarle al joven, recibió una puñalada en un brazo.

Por último, antes de ser perseguido y capturado por los compañeros de ese taxista, el agresor le acertó algunas puñaladas a otro jubilado con el que se cruzó en 9 entre 163 y 164.

Horas después del ataque Geymonat conversó con EL DIA desde la cama del hospital donde está internada.

"Estaba atendiendo a una clienta, cuando escuchamos que gritaban en la calle. Salí a la vereda y vi a un joven que parecía estar golpeando a un abuelo", contó.

“Le grité que no le pegara porque era viejito -siguió-, pero (el atacante) se dio vuelta y recién ahí vi que tenía una cuchilla. Sentí mucho miedo y se me vino encima para empezar a apuñalarme".

Sobre esos terribles instantes, recordó que "me daba con la punta de la cuchilla y con cada puñalada gritaba como poseído invocando el nombre de alguien que no pude identificar", reveló Silvia, quien cree haber escuchado la palabra "Lucifer". Luego de darle unas cinco puñaladas, el agresor amagó a irse. Pero no. Ensangrentada, Geymonat atinó a pedir ayuda en el kiosco de 9 y 163. "Pero la puerta del local estaba cerrada con llave y no salió nadie a asistirme". El agresor volvió por ella. La tiró al piso, donde "me pegó varias puñaladas más. Habrán sido en total entre 15 y 20 ", analizó ante la atenta mirada de su esposo y su hijo.

Geymonat admitió: "Pensé que me mataba. Creí que era el final". 
Diario: El Día

Fecha de edición: 4 de septiembre de 2016

Volanta: ----

Título: Es inimputable el acuchillador de Berisso

Bajada: ---

Firma: ----

Imágenes: nuevamente foto de la señora que salió de la panadería para defender a otra de las víctimas, en la cama del hospital.

Epígrafe: Silvia Geymonat recibió unos 20 cortes al salir en defensa de un jubilado que era apuñalado por el agresor, en 9 y 163.

Tema que aborda el artículo: Relata la situación de Nicolás, en relación con su detención, revisación médica y declaración de inimputabilidad por parte de los peritos, mientras se aguarda su traslado a una unidad penitenciaria. En el título se afirma la inimputabilidad, aunque en el desarrollo de la nota, no queda establecido que el juez efectivamente haya determinado la declaración de inimputabilidad del acusado para este hecho. El resto de la nota vuelve a contar toda la situación que ya ha sido publicada con anterioridad, respecto a la acción que ha tenido como protagonista al detenido y a sus víctimas; lo cual deja en primer plano de la noticia a las víctimas como centro de la información, aunque lo novedoso del artículo se encuentre sólo en el primer párrafo.

Es significativo que sólo en el inicio de la nota esté la novedad -que nuevamente no cita la palabra de expertos ni se fundamenta en el expediente o información proveniente de la causa- y el resto sea reiteración de lo publicado con anterioridad. En este sentido, se cumple lo que plantea Villarruel (2014) en relación con la función de la repetición en lo que tiene que ver con el tratamiento de las noticias judiciales por parte de los medios de comunicación. Lo que esto hace es alimentar a la opinión pública, pero en realidad tiene que ver con que el medio no ha investigado más información al respecto: ante la falta de datos novedosos para aportar, lo que hace es reproducir una y otra vez la misma información, lo cual también ocurre con las imágenes (siempre la 
misma foto para todas las publicaciones, de lo que se infiere que no se ha vuelto a tener contacto con los protagonistas del hecho).

4 de septiembre versión impresa Diario El Día

\begin{tabular}{|c|c|c|c|c|}
\hline \multicolumn{2}{|c|}{$\begin{array}{l}\text { Dx. } \\
\text { Domingo } 4 \text { de septiembre de } 2016\end{array}$} & & & \\
\hline 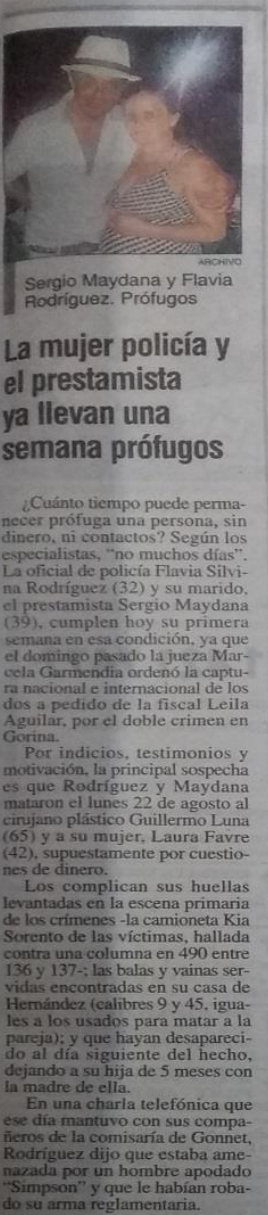 & 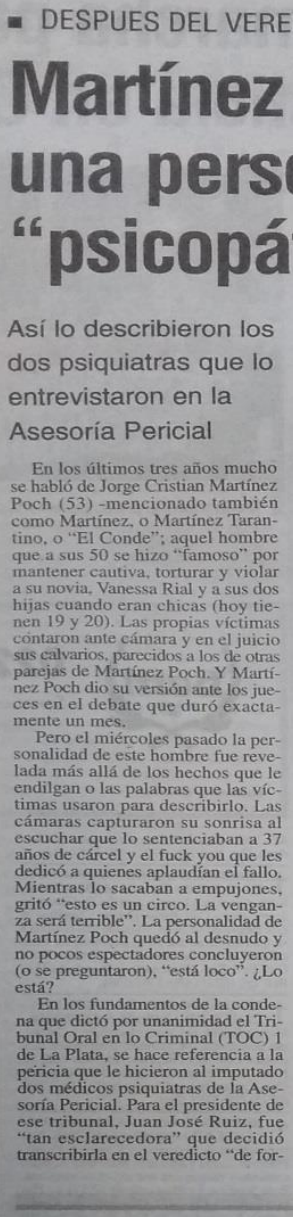 & 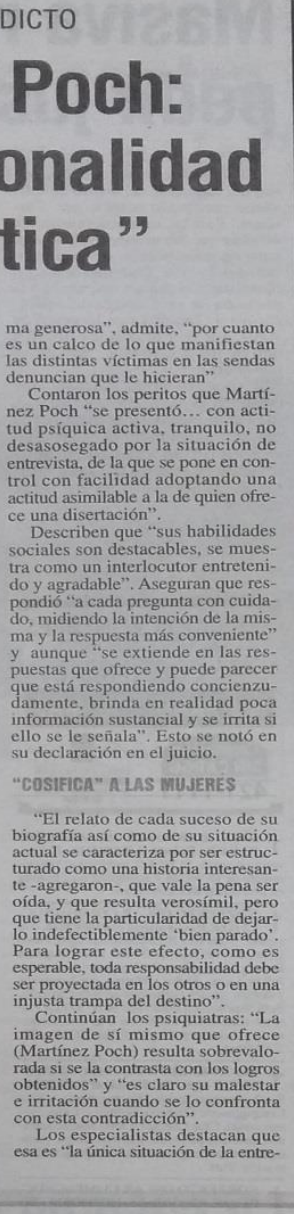 & $\begin{array}{l}\text { vista ante la que aparece malestar. } \\
\text { es decir, cuando percibe un cuestio- } \\
\text { namiento a su imagen sobrevalora- } \\
\text { da, manteniendo en contraste una } \\
\text { afectividadad superficiali, más bien fría, } \\
\text { para cualquier otra circunstancia". } \\
\text { "Describe la ausencia de dificul- } \\
\text { tades en su relación con las muje- } \\
\text { res, pero queda en evidencia que } \\
\text { con ello se alude a la conquista, pero } \\
\text { no al mantenimiento de una rela- } \\
\text { ción estable y satisfactoria", reve- } \\
\text { lan. } \\
\text { El informe continúa analizando } \\
\text { que "la descripción de los atracti- } \\
\text { vos que encuentra en las mismas se } \\
\text { centra en un aspecto cosificado, des- } \\
\text { valido, maleable, sobre el cual ejer- } \\
\text { cería un papel ordenador y de auto- } \\
\text { ridad que de algún modo reafirma } \\
\text { la imagen de símismo que ofrece". } \\
\text { Al momento de describir sus } \\
\text { "características de personalidad". } \\
\text { escriben los expertos: "Seducción } \\
\text { superficial, autovaloración grandio- } \\
\text { sa, necesidad de estímulos, tenden- }\end{array}$ & 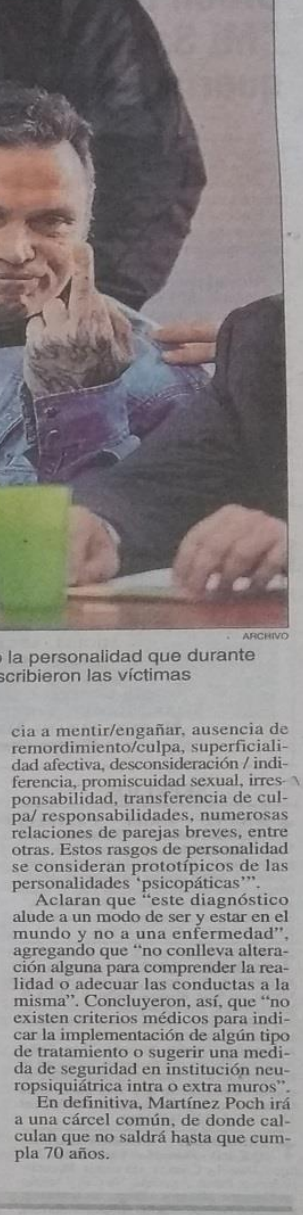 \\
\hline 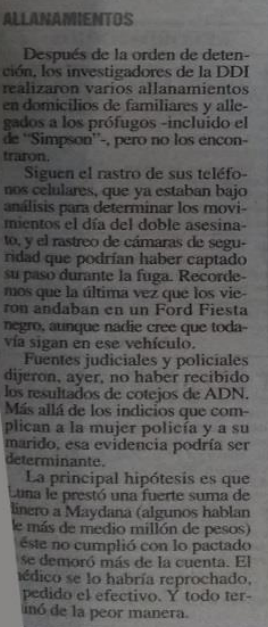 & 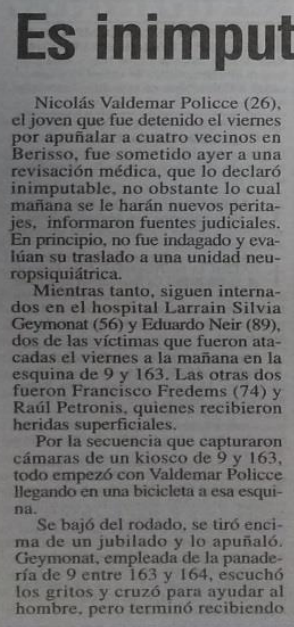 & 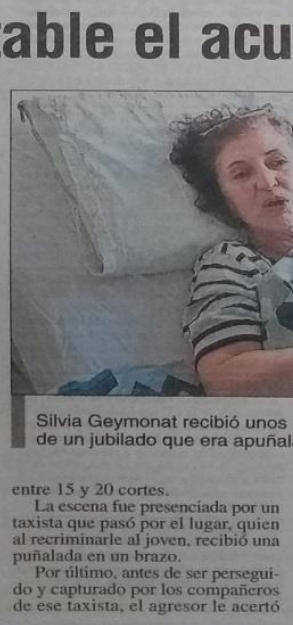 & $\begin{array}{l}\text { algunas puñaladas a otro jubilado } \\
\text { con el que se cruzo en } 9 \text { entre } 163 \\
\text { y } 164 \text {. } \\
\text { Horas después del ataque Geymo- } \\
\text { nat conversó con EL DIA deste la } \\
\text { cama del hospital donde está inter- } \\
\text { nada. destaba atendiendo a una clien- } \\
\text { "Estaba atenden }\end{array}$ & 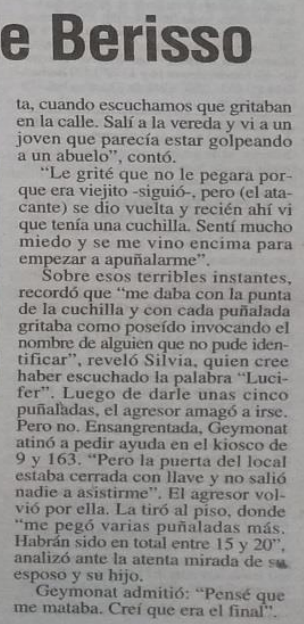 \\
\hline
\end{tabular}




\section{Es inimputable el acuchillador de Berisso}

Nicolás Valdemar Policce (26), el joven que fue detenidoce (26) por apuñalar a cuatro vecines Berisso, fue sometido ayer a una revisación médica, que lo declaró inimputable, no obstante lo cual mañana se le harán nuevos peritajes, informaron fuentes judiciales. En principio, no fue indagado y evalúan su traslado a una unidad neuropsiquiátrica.

Mientras tanto, siguen internados en el hospital Larrain Silvia Geymonat (56) y Eduardo Neir (89). dos de las víctimas que fueron atacadas el viernes a la mañana en la esquina de 9 y 163 . Las otras do fueron Francisco Fredems (74) Raúl Petronis, quienes recibiero heridas superficiales.

Por la secuencia que capturaron cámaras de un kiosco de 9 y 163 , todo empezó con Valdemar Policce llegando en una bicicleta a esa esquna.

Se bajó del rodado, se tiró encima de un jubilado y lo apunalo. Geymonat, empleada de la panadería de 9 entre 163 y 164 , escuch los gritos y cruzó para ayudar a

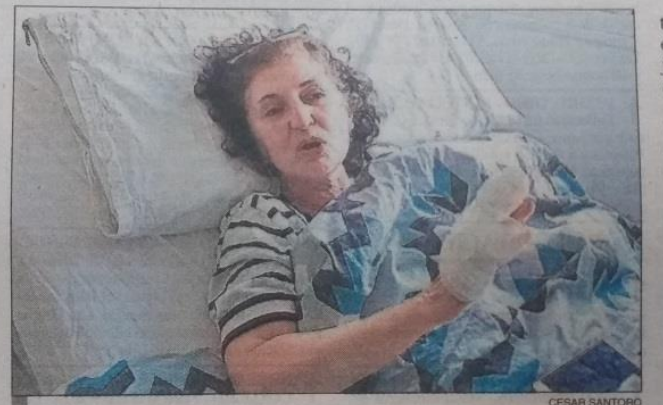

Silvia Geymonat recibió unos 20 cortes al salir en defensa de un jubilado que era apuñalado por el agresor, en 9 y 163 (15 y 20 cortes. entre 15 y 20 cortes.
La escena fue presenciada por un La escena fue presenciada por un
taxista que pasó por el lugar, quien taxista que paso por even, recibió una al recriminarle al joven,

Diario: El Día

Fecha de edición: 4 de septiembre de 2016

Tamaño que ocupa el artículo: Un cuarto de página. Página 37, tercera página de la sección "policiales", sector inferior de la hoja.

Volanta: ---

Título: Es inimputable el acuchillador de Berisso.

Bajada: ----

Firma:

Imágenes: Misma foto que en la versión digital de ese mismo día.

Epígrafe: Silvia Geymonat recibió unos 20 cortes al salir en defensa de un jubilado que era apuñalado por el agresor, en 9 y 163.

Destacado: --- 
Tema que aborda el artículo: Misma nota que en la versión digital del mismo día.

8 de septiembre versión impresa diario El Día

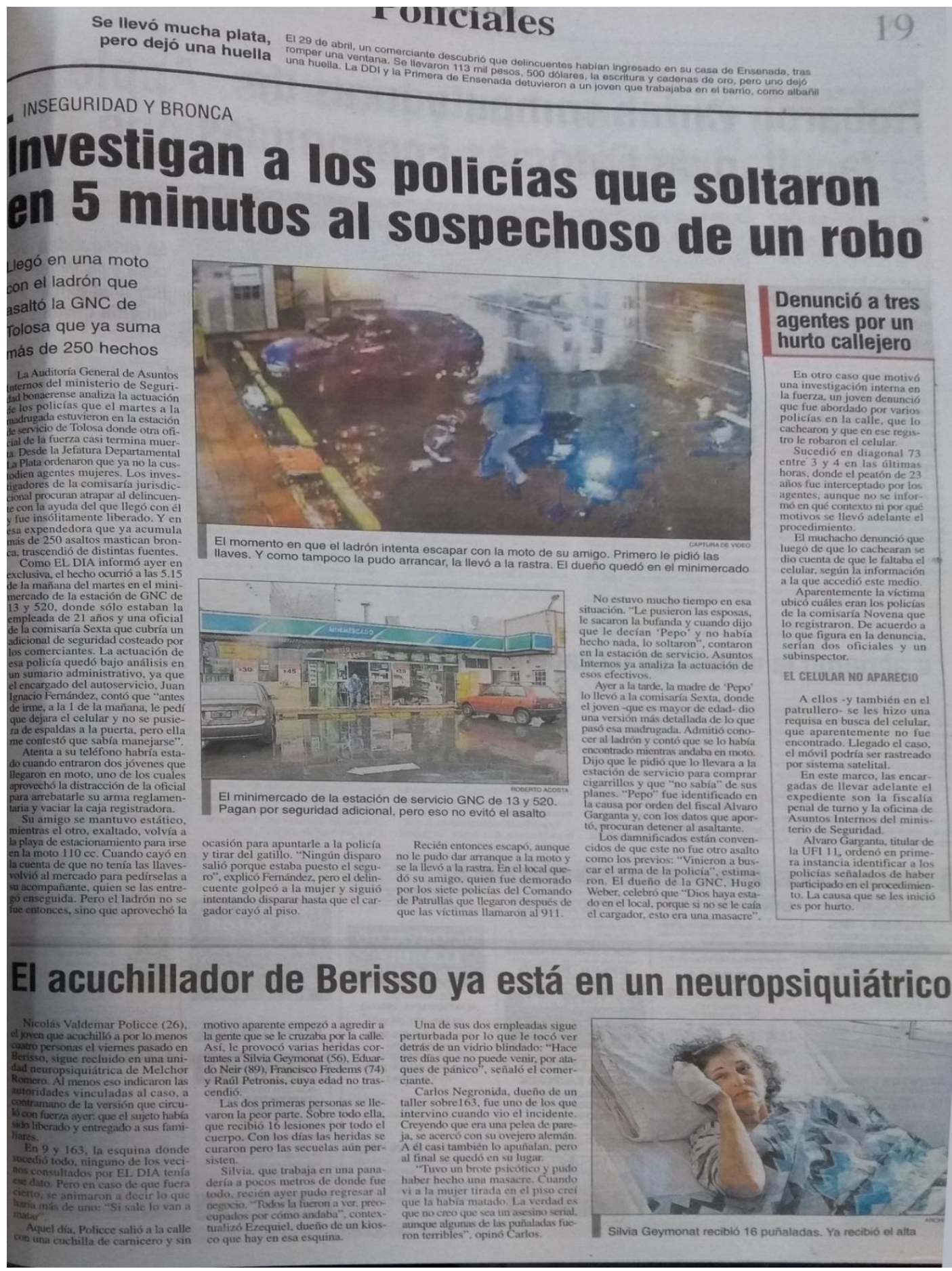




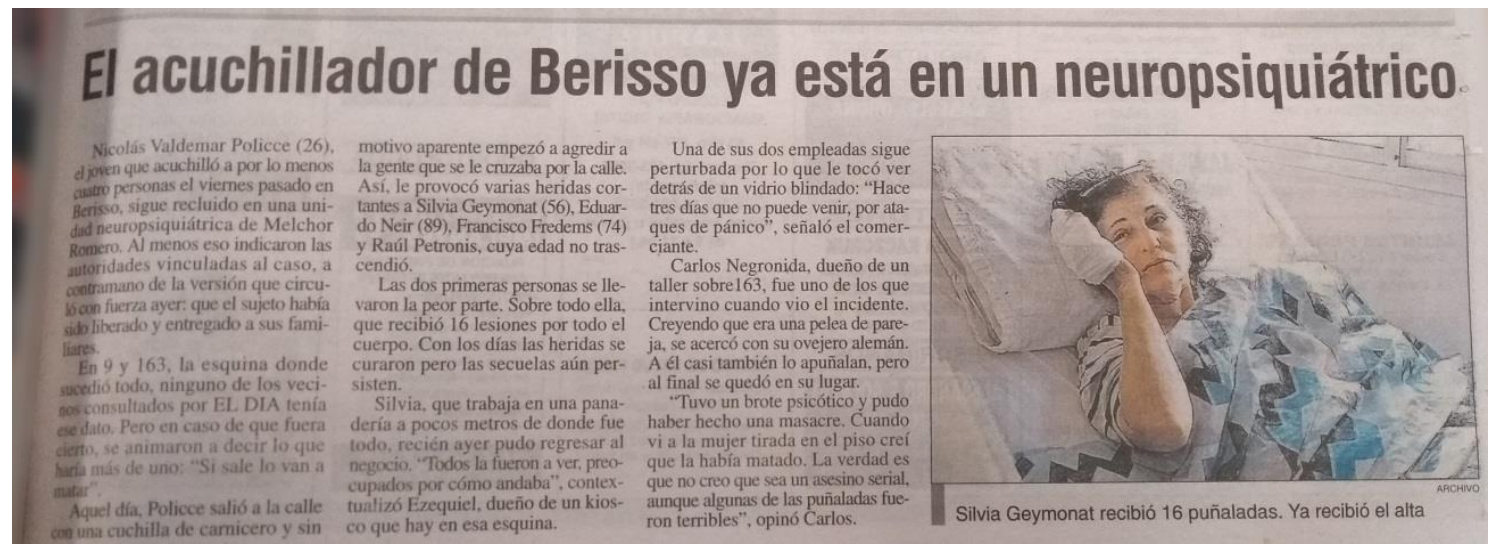

Diario: El Día

Fecha de edición: 8 de septiembre de 2016

Tamaño que ocupa el artículo: un cuarto de página. Sector inferior de la hoja, primera plana de la sección "Policiales".

\section{Volanta:--}

Título: El acuchillador de Berisso ya está en un neuropsiquiátrico.

\section{Bajada: ----}

Firma: ---

Imágenes: misma foto que en la versión digital de ese mismo día.

Epígrafe: Silvia Geymonat recibió 16 puñaladas. Ya recibió el alta.

Tema que aborda el artículo: misma nota que en la versión digital de ese día (que se analiza a continuación).

El 8 de septiembre, sale en la versión digital del diario El Día ${ }^{x \times x i}$, la última noticia que se ha podido rastrear sobre este caso en ese matutino hasta el 2 de noviembre de 2018. La misma, da cuenta de la internación de Nicolás en un neuropsiquiátrico de la ciudad de La Plata. 


\section{H}

三Menú La Región Deportes $\mid$ Policiales Espectáculos $\mid$ Política y Economía $\mid$ El mundo Sociedad Opinión

\section{El acuchillador de Berisso ya está en un neuropsiquiátrico}

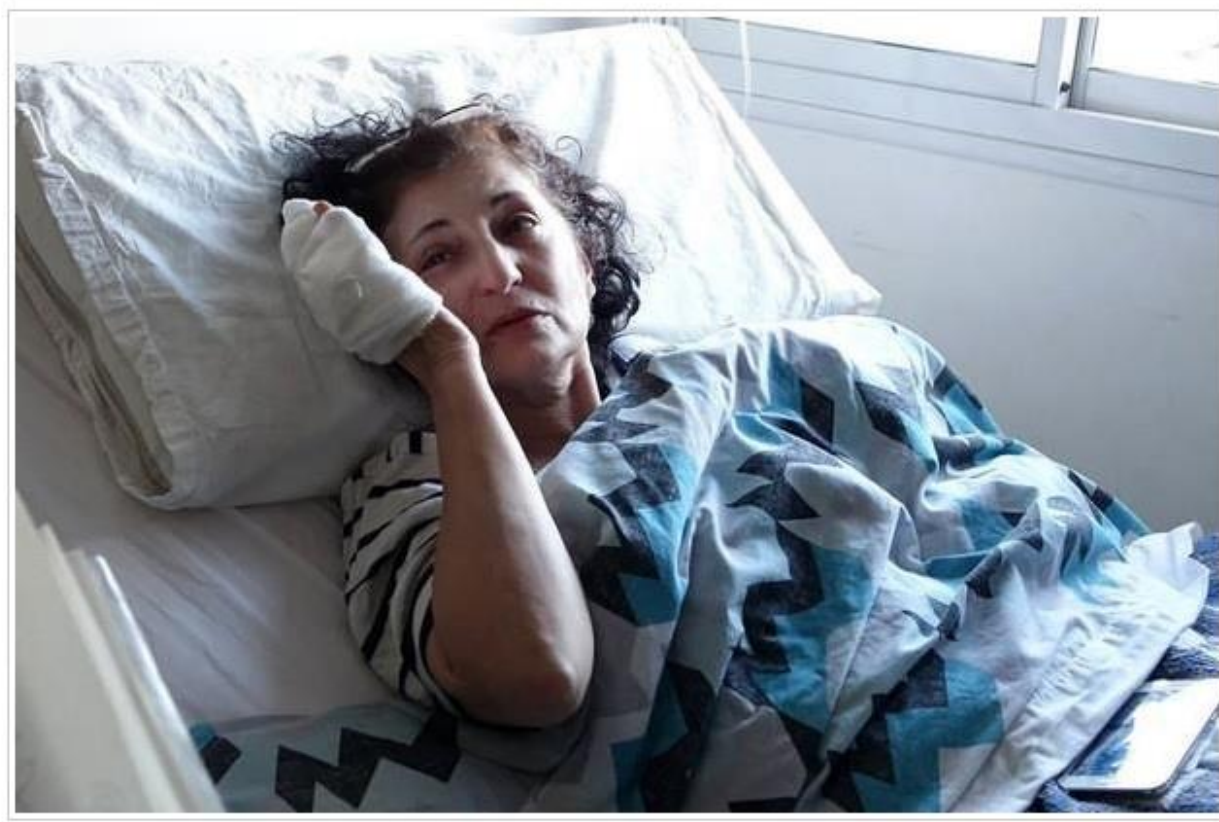

SILVIA GEYMONAT RECIBIÓ 16 PUÑALADAS. YA RECIBIÓ EL ALTA 
Nicolás Valdemar Policce (26), el joven que acuchilló a por lo menos cuatro personas el viernes pasado en Berisso, sigue recluido en una unidad neuropsiquiátrica de Melchor Romero. Al menos eso indicaron las autoridades vinculadas al caso, a contramano de la versión que circuló con fuerza ayer: que el sujeto había sido liberado y entregado a sus familiares.

En 9 y 163, la esquina donde sucedió todo, ninguno de los vecinos consultados por EL DIA tenía ese dato. Pero en caso de que fuera cierto, se animaron a decir lo que haría más de uno: "Si sale lo van a matar".

Aquel día, Policce salió a la calle con una cuchilla de carnicero y sin motivo aparente empezó a agredir a la gente que se le cruzaba por la calle. Así, le provocó varias heridas cortantes a Silvia Geymonat (56), Eduardo Neir (89), Francisco Fredems (74) y Raúl Petronis, cuya edad no trascendió.

Las dos primeras personas se llevaron la peor parte. Sobre todo ella, que recibió 16 lesiones por todo el cuerpo. Con los días las heridas se curaron pero las secuelas aún persisten.

Silvia, que trabaja en una panadería a pocos metros de donde fue todo, recién ayer pudo regresar al negocio. "Todos la fueron a ver, preocupados por cómo andaba", contextualizó Ezequiel, dueño de un kiosco que hay en esa esquina.

Una de sus dos empleadas sigue perturbada por lo que le tocó ver detrás de un vidrio blindado: "Hace tres días que no puede venir, por ataques de pánico", señaló el comerciante.

Carlos Negronida, dueño de un taller sobre163, fue uno de los que intervino cuando vio el incidente. Creyendo que era una pelea de pareja, se acercó con su ovejero alemán. A él casi también lo apuñalan, pero al final se quedó en su lugar.

"Tuvo un brote psicótico y pudo haber hecho una masacre. Cuando vi a la mujer tirada en el piso creí que la había matado. La verdad es que no creo que sea un asesino serial, aunque algunas de las puñaladas fueron terribles", opinó Carlos.

\section{Diario: El Día}

Fecha de edición: 8 de septiembre de 2016

Volanta: ---

Título: El acuchillador de Berisso ya está en un neuropsiquiátrico 
Bajada: ----

Firma:

Imágenes: nuevamente foto de la señora que salió de la panadería para defender a otra de las víctimas, en la cama del hospital.

Epígrafe: Silvia Geymonat recibió 16 puñaladas. Ya recibió el alta.

Tema que aborda el artículo: Toda la nueva información que aporta el artículo sobre el caso se encuentra en el primer párrafo, en donde indica que Nicolás se encuentra en una Unidad penitenciaria neuropsiquiátrica (contrario a lo que podría pensarse con el título respecto a que podría estar en un hospital, se encuentra en una cárcel). El título es significativo en tanto indica que "ya" se encuentra en un neuropsiquiátrico, como si ese fue el destino esperable sin dudas para este sujeto, lo cual da la pauta del imaginario respecto al lugar que le corresponde al "loco peligroso". Abona esta construcción el hecho de que, en el resto de la nota, lo que vuelve a aparecer es la reiteración de los datos ya sabidos sobre la situación que llevó a Nicolás al centro de la escena, y nuevamente haciendo foco sobre las víctimas, donde la foto de una de ellas vuelve una vez más a ser la cara visible de esta noticia, aunque lo que se busque informar no sea sobre la víctima sino sobre el destino de Nicolás.

Aparece también en el título, la nominación del acusado como "El acuchillador de Berisso", reduciendo al joven al hecho que lo tuvo como protagonista.

Salvo el párrafo que dedican a informar sobre la situación actual del joven, y en el cual no se da a conocer la fuente mediante la cual llegaron a ese dato, el resto de la nota está construido sobre la base de los testimonios de víctimas y testigos, desvestidos absolutamente de objetividad.

Resulta llamativo también que en otras oportunidades se menciona que Silvia recibió "20 puñaladas", "cerca de 20 puñaladas" o "al menos 20 puñaladas" y en esta publicación dicen "16 puñaladas", demostrando una falta de certeza absoluta respecto a la información precisa sobre el caso. 
En otros medios, continuó saliendo información sobre este caso que da cuenta del avance de la causa. Se reproducen a continuación algunas de esas publicaciones, ya que resulta significativo el "olvido" de Nicolás por parte de El Día, quien pareciera que, para ese medio, dejó de ser noticia una vez que fue trasladado a la Unidad neuropsiquiátrica N ${ }^{\circ} 34$ de La Plata. Con relación a esta desaparición del seguimiento por parte del medio analizado, Villarruel (2014) sostiene que:

Los medios suelen cubrir el comienzo del evento -las detenciones, el velatorio del asesinado, los allanamientos en búsqueda de acusados- y luego abandonan la cobertura. Como la parte más "morbosa" del caso ya sucedió y ya no vende, no sabemos si el detenido del comienzo de la noticia era o no el asesino (pág. 30).

La noticia constituye solamente un producto a la venta, que en cuanto deja de producir interés en la audiencia, es olvidado, al igual que los actores que fueron protagonistas de la escena. Es lo que Zaffaroni refiere respecto al "uso" que hacen los medios de las personas, sin importarle los efectos que en ellos produzca.

Diario Hoy, 4 de octubre de $2016^{\text {xxxii }}$ 


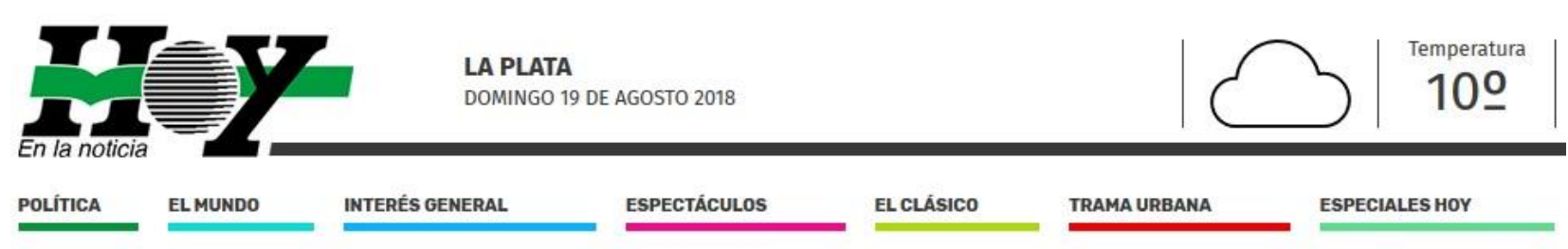

\section{Loco del cuchillo: el acusado es psicótico y tiene delirios místicos}

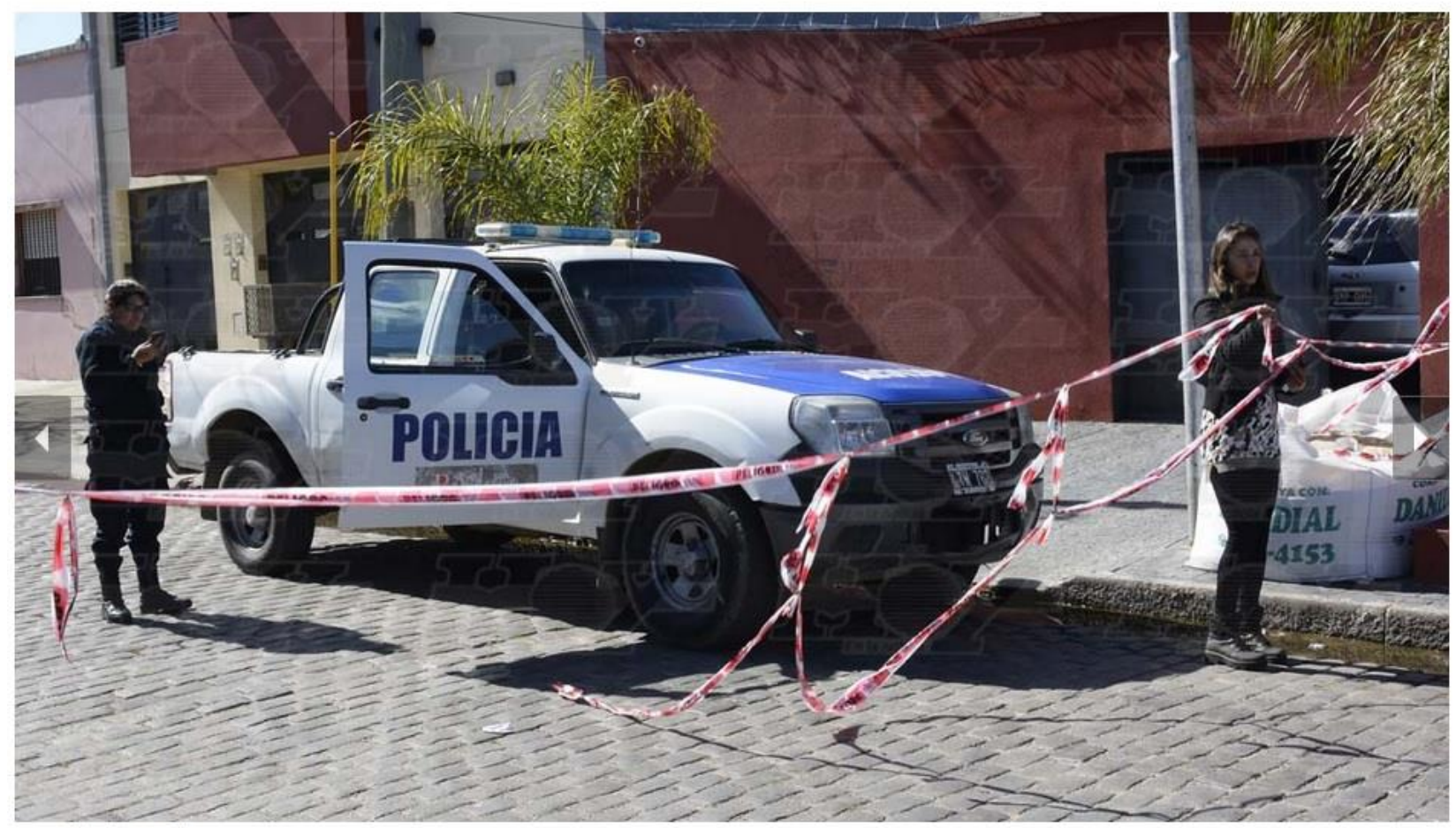

Foto diario Hoy / D.A. 
TRAMA URBANA De esta manera lo determinaron las pericias, por lo cual es inimputable. El sujeto

04/10/2016 - 19:54hs

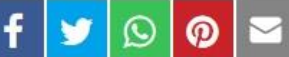

\author{
apuñaló a cuatro personas a principios de septiembre.
}

\begin{abstract}
Los resultados de las pericias realizadas a Nicolás Pollice Waldemar (26), quien apuñaló a cuatro personas en Berisso el 3 de septiembre último, determinaron que presenta
\end{abstract} "psicopatología con criterios suficientes para conformar un cuadro de características psicóticas".

\begin{abstract}
De acuerdo al informe psiquiátrico al que accedió HOY, el sujeto se presentó a la entrevista "orientado en tiempo y espacio; la atención se encuentra inestable, dirigida al entrevistador y por momentos a sus vivencias internas.Presenta fallas mnésicas globales".

"El pensamiento se encuentra enlentecido en su curso, no pudiendo mantener la idea directriz, dada la arborización ideativa que presenta siendo su contenido delirante. Si bien la ideación continua presentando contenidos patológicos autorreferenciales de perjuicio, de jerarquía delirante a un mecanismo interpretativo, suegen también contenidos místicos. Juicio crítico-valorativo desviado de la realidad", agrega el informe de la especialista.
\end{abstract}

El hecho ocurrió durante la mañana del 3 de septiembre último, cuando cuatro personas resultaron brutalmente apuñaladas a en Berisso -en los alrededores de calle 9 entre 162 y 163-, al ser atacadas por un joven que manipulaba un cuchillo de carnicero.

Luego de ser detenido, las primeras hipótesis señalaron que Waldemar no tenía noción de sus actos, lo que fue corroborado por la perito. La misma concluyó que "al momento del hecho que se le imputa, por presentar alteración morbosa de sus facultades mentales no pudo comprender la criminalidad del acto y/o dirigir sus acciones".

"Por continuar las causales de peligrosidad para sí y/o terceros, Pollice debe continuar bajo tratamiento psiquiátrico", agrega el escrito. El acusado está representado por los abogados Marcelo Botindari y Santiago Irisarri, por intermedio de su familia.

\section{Diario: Hoy}

Fecha de edición: 4 de octubre de 2016

Volanta: ---

Título: Loco del cuchillo: el acusado es psicótico y tiene delirios místicos

Bajada: De esta manera lo determinaron las pericias, por lo cual es inimputable. El sujeto apuñaló a cuatro personas a principios de septiembre.

Firma: ---

Imágenes: Foto de una escena delimitada con cintas de seguridad y un móvil policial, presuntamente del momento del hecho.

Epígrafe: Foto Diario Hoy. D/A.

Destacado: bajada en cursiva. 
Tema que aborda el artículo: El título de la publicación comienza con la nominación del sujeto como el "loco del cuchillo", denominación que acompaña todas las notas elaboradas por este medio. El artículo da cuenta del diagnóstico al que supuestamente arribaron los profesionales cuando evaluaron a Nicolás, indicando una psicopatología con características psicóticas. En los párrafos siguientes, se transcriben pasajes del informe al que el medio ha accedido y que sería el que se encuentra en el expediente judicial del caso. El artículo concluye indicando que el sujeto continúa en tratamiento y que es representado por dos abogados que se encuentran en contacto con la familia del acusado. Resulta significativo que se haga referencia a que el joven "es" inimputable, lo cual implica una falacia desde el punto de vista jurídico, dado que, como se desarrolló previamente en este trabajo, las personas no "son" inimputables, sino que se les declara la inimputabilidad por la comisión de una acción antijurídica por no comprender en ese momento la criminalidad del hecho, pero tranquilamente pueden ser imputados de otro hecho si al momento del mismo sí pudiera comprender la criminalidad del mismo. Por lo tanto, la inimputabilidad no es una condición del sujeto.

Lo que también llama la atención del abordaje que realiza este medio, es el énfasis que pone en la presunta psicopatología del sujeto, reforzando la etiqueta que le otorgan a Nicolás como "el loco del cuchillo".

Diario Hoy $27 / 10$ versión digital ${ }^{\text {xxiii }}$ 


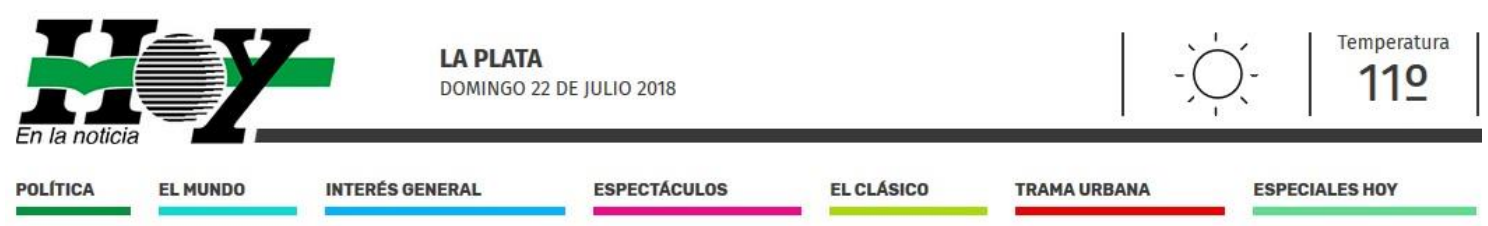

\section{“Loco del cuchillo", absuelto por inimputable}

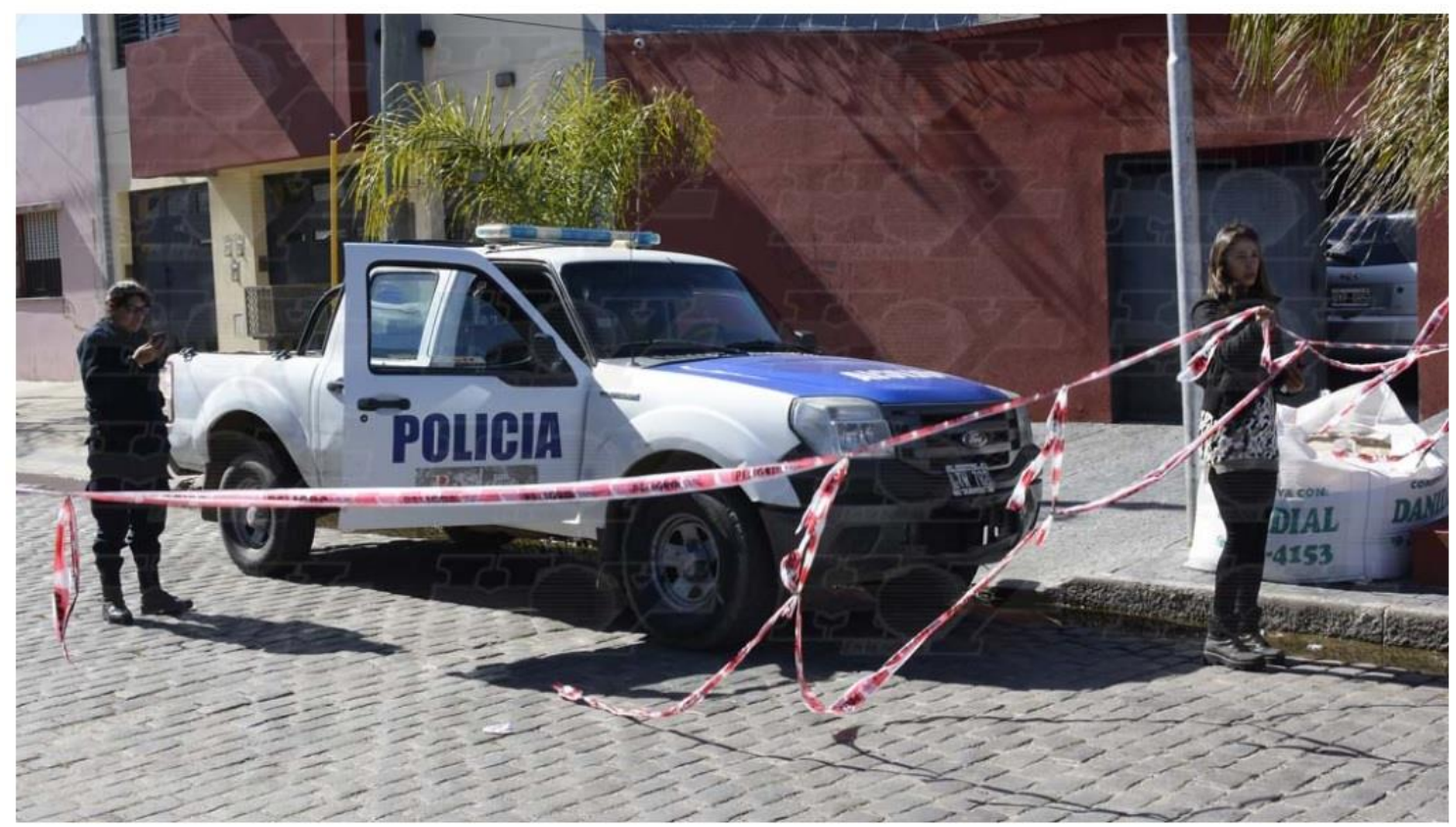

TRAMA URBANA Así lo resolvió el juez Guillermo Atencio. La pericia determinó que el agresor, Pollice mes pasado en Berisso

El juez de Garantías N1, Guillermo Atencio, absolvió a Nicolás Pollice Waldemar (26), quien apuñaló a cuatro personas en Berisso el 3 de septiembre último, por ser inimputable.

El magistrado tomó esa decisión por pedido del fiscal Álvaro Garganta, teniendo en cuenta, además, la pericia psiquiátrica realizada al acusado. En la misma se indicó que la persona en cuestión presenta "psicopatología con criterios suficientes para conformar un cuadro de características psicóticas".

Según el informe, el sujeto llegó a la entrevista "orientado en tiempo y espacio, pero su atención se encontraba inestable, dirigida al entrevistador y por momentos a sus vivencias internas, presentando fallas mnésicas globales (conservación de recuerdos). El pensamiento se encuentra enlentecido en su curso, no pudiendo mantener la idea directriz, dada la arborización ideativa que presenta, siendo su contenido delirante. Si bien la ideación continúa presentando contenidos patológicos autorreferenciales de perjuicio, de jerarquía delirante a un mecanismo interpretativo, surgen también contenidos místicos. Juicio crítico-valorativo desviado de la realidad", agrega el escrito de la especialista. 


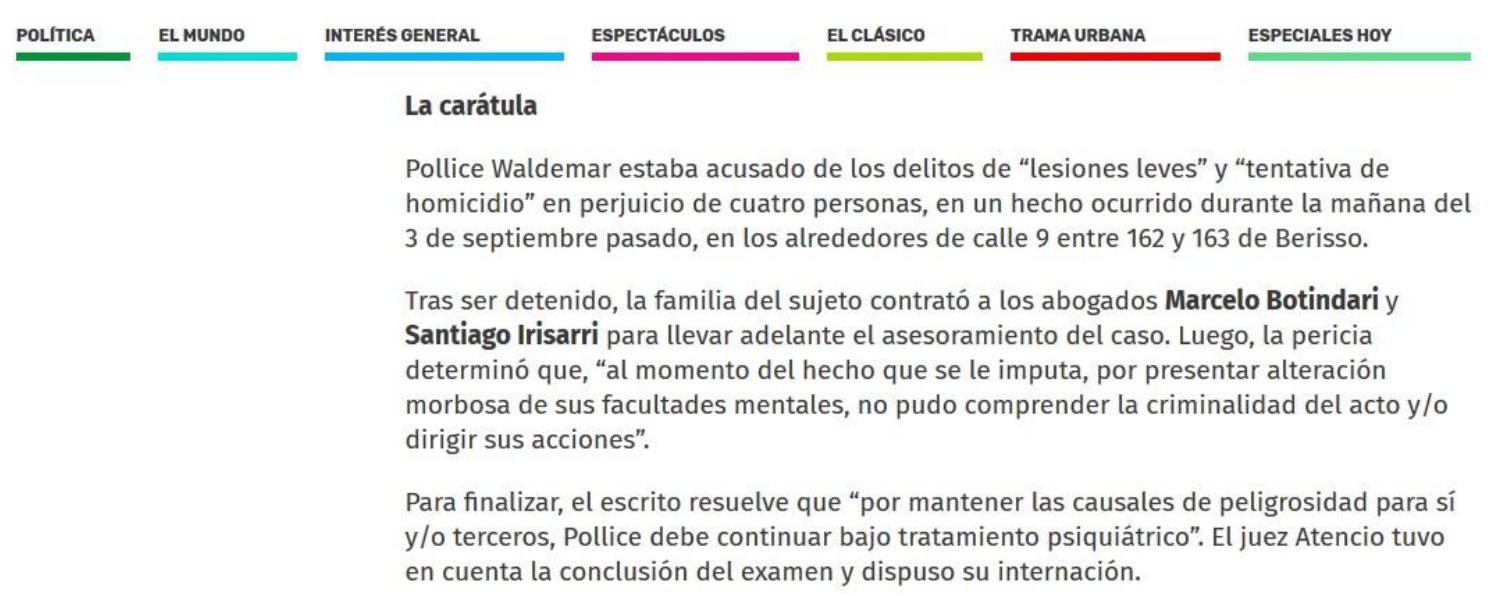

\section{f}

Diario: Hoy

Fecha de edición: 10 de octubre de 2016

Volanta: ---

Título: "Loco del cuchillo", absuelto por inimputable

Bajada: Así lo resolvió el juez Guillermo Atencio. La pericia determinó que el agresor, Pollice Waldemar, es psicótico y tiene delirios místicos. Había apuñalado a cuatro personas el mes pasado en Berisso

Firma: ----

Imágenes: Foto de una escena delimitada con cintas de seguridad y un móvil policial, presuntamente del momento del hecho (misma foto que el 4 de octubre).

\section{Epígrafe:}

Destacado: el texto que aparece en la bajada

\section{Subnotas: ---}

Tema que aborda el artículo: Este diario vuelve a llamar a Nicolás como "el loco del cuchillo", nominación que es tomada también por otros medios digitales y portales de información. El artículo cuenta -sin citar fuentes- acerca de la situación procesal de Nicolás, quien habría sido absuelto por el juez de garantías por considerarlo inimputable. Para dar cuenta de la inimputabilidad 
del joven, se utiliza como fuente parte textual de la pericia de los profesionales que determinaron un cuadro psicótico en el joven al momento de la comisión de la acción antijurídica. Asimismo, se hace referencia a la carátula de la causa y culmina el artículo haciendo mención de que por su situación de "peligrosidad" el sujeto debe continuar en tratamiento, por lo que seguirá "internado".

Diario Hoy, 16 de febrero de $2018^{\text {xxiv }}$

Enla noticia

\section{En diciembre será el juicio al "Loco del cuchillo"}

El próximo 5 de diciembre, el Tribunal Oral en lo Criminal №5 de La Plata comenzará el juicio a Nicolás Pollice Waldemar (26), acusado de apuñalar a cuatro personas en Berisso el 3 de septiembre de 2017. Según la evaluación de los psiquiatras, el joven es inimputable.

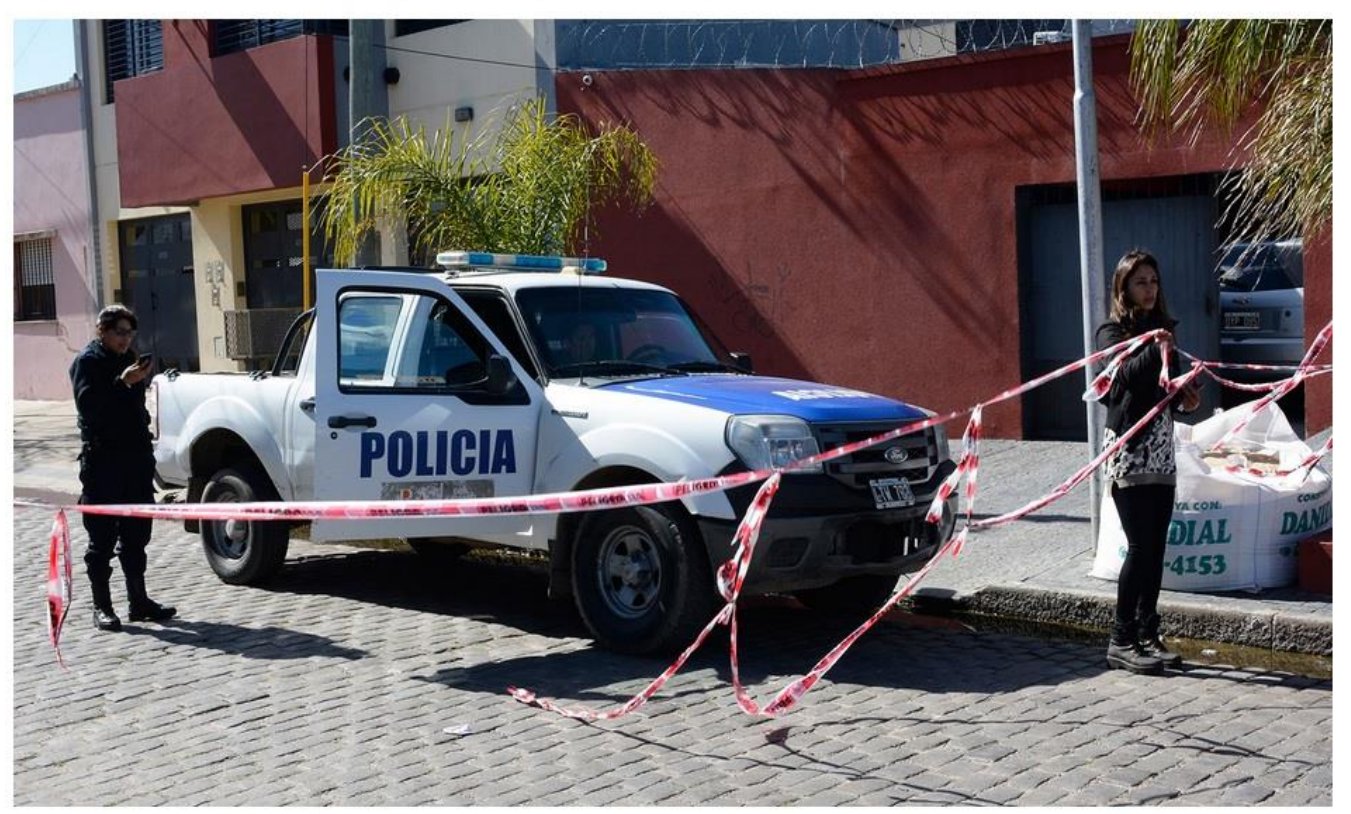


TRAMA URBANA 16/02/2018- 09:10hs

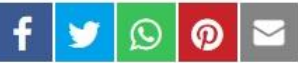

El próximo 5 de diciembre, el Tribunal Oral en lo Criminal №5 de La Plata comenzará el juicio a Nicolás Pollice Waldemar (26), acusado de apuñalar a cuatro personas en Berisso el 3 de septiembre de 2017. Según la evaluación de los psiquiatras, el joven es inimputable.

Luego de que ocurrieron los ataques, el juez Guillermo Atencio ordenó que se le realizaran pericias al imputado, además de su internación en el Neuropsiquiátrico de Melchor Romero. Los estudios señalaron que Pollice presenta "psicopatología con criterios suficientes para conformar un cuadro de características psicóticas". Según el informe, el sujeto tiene señales claras de demencia.

En el informe, los psquiatras también expresaron que el acusado no puede mantener una idea, ya que en la misma hay "contenido delirante, con contenidos místicos que desvían la realidad". El imputado está representado por los abogados Marcelo Botindari y Santiago Irisarri; está previsto que el debate dure solo dos días: 5 y 6 de diciembre de este año, tras lo cual los jueces emitirán un veredicto.

Diario: Hoy

Fecha de edición: 16 de febrero de 2018

Volanta: ---

Título: En diciembre será el juicio al "Loco del cuchillo"

Bajada: El próximo 5 de diciembre, el Tribunal Oral en lo Criminal No5 de La Plata comenzará el juicio a Nicolás Pollice Waldemar (26), acusado de apuñalar a cuatro personas en Berisso el 3 de septiembre de 2017. Según la evaluación de los psiquiatras, el joven es inimputable.

Firma: ---

Imágenes: Foto de una escena delimitada con cintas de seguridad y un móvil policial, presuntamente del momento del hecho (misma foto que el 4 y 10 de octubre de 2016).

\section{Epígrafe: ---}

\section{Destacado: ---}

Tema que aborda el artículo: El título de la nota vuelve a nominar al sujeto como el "loco del cuchillo", como en publicaciones previas del mismo medio. El artículo es breve y relata que se ha fijado fecha para juicio a Nicolás, para los días 5 y 6 de diciembre, luego de lo cual el tribunal dictará un veredicto. El resto de la información que figura en esta noticia, son elementos que ya han sido expresados en artículos anteriores publicados por este mismo 
medio, como frases extraídas de los informes periciales y los abogados que lo representan. Lo interesante de esta noticia en particular es que se hace referencia a la inimputabilidad del acusado y que se ha fijado fecha de juicio, sin un tratamiento de lo que esto implica, ¿qué tipo de juicio es el que se va a llevar a cabo? Porque si se ha declarado la inimputabilidad y el sobreseimiento del sujeto, el juicio no podría ser para determinar su culpabilidad en el hecho del 2 de septiembre de 2016, dado que la justicia ya lo habría declarado irresponsable por no comprender al momento del hecho la antijuridicidad de la acción cometida. Estas contradicciones encontradas en la información jurídica del caso son las que dan cuenta de lo que plantea Villarruel (2014) respecto de la ignorancia de los periodistas a la hora de informar sobre temas en los cuales no tienen formación, multiplicando la desinformación. No importa tanto difundir la verdad de lo ocurrido, sino construir una verdad que venda, la información precisa, en ese caso, es totalmente accesoria.

Diario El Día, 2 de noviembre de 2018. Al cierre de esta tesis, sale un nuevo artículo periodístico sobre el caso en análisis. En esta oportunidad, respecto a la declaración de inimputabilidad de Nicolás por el hecho del 3 de septiembre de 2016. La información publicada pudo corroborarse con fuentes cercanas al protagonista de la historia.

Diario El Día del 2 de noviembre de 2018, versión digital ${ }^{\mathrm{xx} \times \mathrm{v}}$ 


\section{H.}

EMenú La Región Deportes Policiales Espectáculos Políticay Economía El mundo Sociedad Opinión

POLICIALES

EN BERISSO

\section{Declararon inimputable al joven que atacó a 4 vecinos}

2 de Noviembre de 2018 |03-56 | Publicado en Edición Impresa

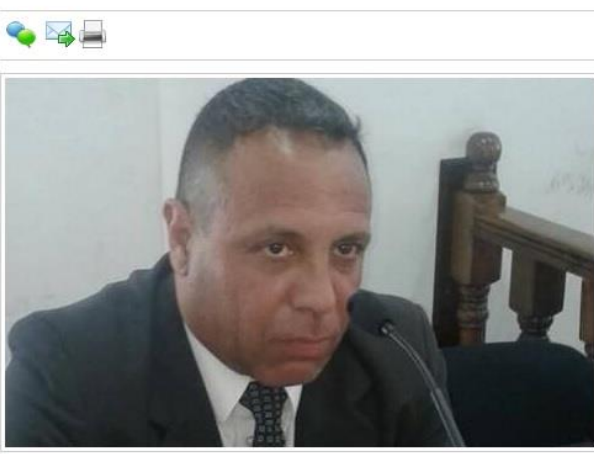

M. BOTINDARI, DEFENSOR in $y f_{i}$

[AA $A A^{*}$

Nicolás Waldemar Pollice (28), el joven que hace poco más de dos años atacó a cuchilladas a cuatro personas en Berisso, fue declarado inimputable por la jueza María Isabel Martiarena, del Tribunal Oral y Criminal V.

En el veredicto absolutorio, la jueza dispuso la aplicación de una medida de seguridad curativa para Pollice a cumplir "en el ámbito de del Servicio Penitenciario Bonaerense, con los resguardos y tratamientos sugeridos", para que "se le brinde tratamiento psicológico, psiquiátrico, terapéutico y farmacológico de manera permanente”, se indicó en la resolución a la que accedió este diario.

Esa medida se implementará hasta que "sea viable el alta médica y la desaparición de la peligrosidad del causante para sí y/o terceros, cesando en esa oportunidad la intervención del presente fuero penal”, agrega el fallo, aclarando que el tratamiento continuará luego de manera permanente, bajo la órbita de un juzgado de familia competente.

INESPERADO

El hecho ocurrió el 3 de septiembre de 2016 en los alrededores de 9 entre 162 y 163 de Berisso, cuando el muchacho, que no tenía antecedentes psiquiátricos, atacó a cuatro vecinos con un cuchillo, sin motivos.

Una de las pocas personas que intentó ayudarlo fue una mujer de 56 años que recibió entre 15 y 20 cortes y tuvo que ser internada en el hospital Larrain, igual que un jubilado de 89 años.

Los otros dos heridos sufrieron heridas leves.

En la primera audiencia del juicio la fiscal Leila Aguilar y los defensores particulares de Pollice, Marcelo Botindari y Santiago Irisarri, coincidieron en que el acusado fue el autor de los ataques, como en el hecho de que al momento de ejecutarlos el joven estaba "bajo el padecimiento de una psicopatología con criterio suficiente para conformar un cuadro de características psicopáticas retrospectivas”. Dicho en otras palabras, presentaba una alteración morbosa de sus facultades mentales, que le impidió "comprender la criminalidad de sus actos", concluyó la justicia en virtud de los informes periciales. 
Diario: El Día

Fecha de edición: 2 de noviembre de 2018

Volanta: ---

Título: Declararon inimputable al joven que atacó a 4 vecinos

Bajada: Nicolás Waldemar Pollice (28), el joven que hace poco más de dos años atacó a cuchilladas a cuatro personas en Berisso, fue declarado inimputable por la jueza María Isabel Martiarena, del Tribunal Oral y Criminal V.

En el veredicto absolutorio, la jueza dispuso la aplicación de una medida de seguridad curativa para Pollice a cumplir "en el ámbito de del Servicio Penitenciario Bonaerense, con los resguardos y tratamientos sugeridos", para que "se le brinde tratamiento psicológico, psiquiátrico, terapéutico y farmacológico de manera permanente", se indicó en la resolución a la que accedió este diario.

Firma: ----

Imágenes: Foto a color de uno de los abogados defensores de Nicolás.

Epígrafe: M. Botinardi, defensor.

\section{Destacado:}

\section{Subnotas: ---}

Tema que aborda el artículo: En el artículo se hace referencia a la declaración de inimputabilidad de Nicolás. Llama la atención en las frases textuales tomadas de la resolución dictada por la jueza, el hecho de la aplicación de medida de seguridad "curativa" a cumplirse en el "Servicio Penitenciario Bonaerense", lugar en el cual se encuentra detenido el joven desde el momento del hecho; se hace referencia a que la misma es para que reciba tratamiento psicológico, psiquiátrico, terapéutico y farmacológico de manera permanente", demostrándose un desconocimiento total de lo normado en la ley de salud mental, la cual indica que el abordaje terapéutico de las personas con padecimiento mental deben ser por medio de un equipo interdisciplinario -no diversos tratamientos simultáneos-, atendiendo a la 
integralidad del sujeto, que el dispositivo privilegiado para trabajar debe ser el más cercano a la comunidad, y no el encierro o internación, a menos de encontrarse una situación de riesgo cierto e inminente para sí o para terceros cierto remite a certeza, inminente, a la inmediatez, ahora-, e ignorando también que la ley estipula que la medicación debe ser sólo en casos de considerarse necesario el suministro de la misma, con revisión periódica procurando el retiro de la misma, en caso de ser posible, del todo (la resolución dice "tratamiento farmacológico de manera permanente").

A continuación, se hace mención de que la medida de seguridad será implementada hasta que "sea viable el alta médica y la desaparición de la peligrosidad del causante para sí y/o terceros, cesando en esa oportunidad la intervención del presente fuero penal" y pasando a la órbita del juzgado de familia. En esto puede advertirse cómo el concepto de peligrosidad sigue siendo lo que dirige la determinación por parte de la jueza.

Luego de estos tres párrafos en los que se presenta la novedad del caso, ligada al avance de la causa judicial y esta nueva resolución con respecto a la situación de Nicolás, la información que continúa es la misma que ya se había publicado con anterioridad, dando cuenta del momento del hecho, las víctimas y lo acontecido en la primera audiencia del juicio en donde ya se había solicitado la declaración de inimputabilidad.

Diario El Día, 2 de noviembre de 2018, versión impresa.

Sección Policiales, tercera página. Página 21 del diario. 


\section{Un ferroviario complicó a los policías acusados de matar a un joven en City Bell}

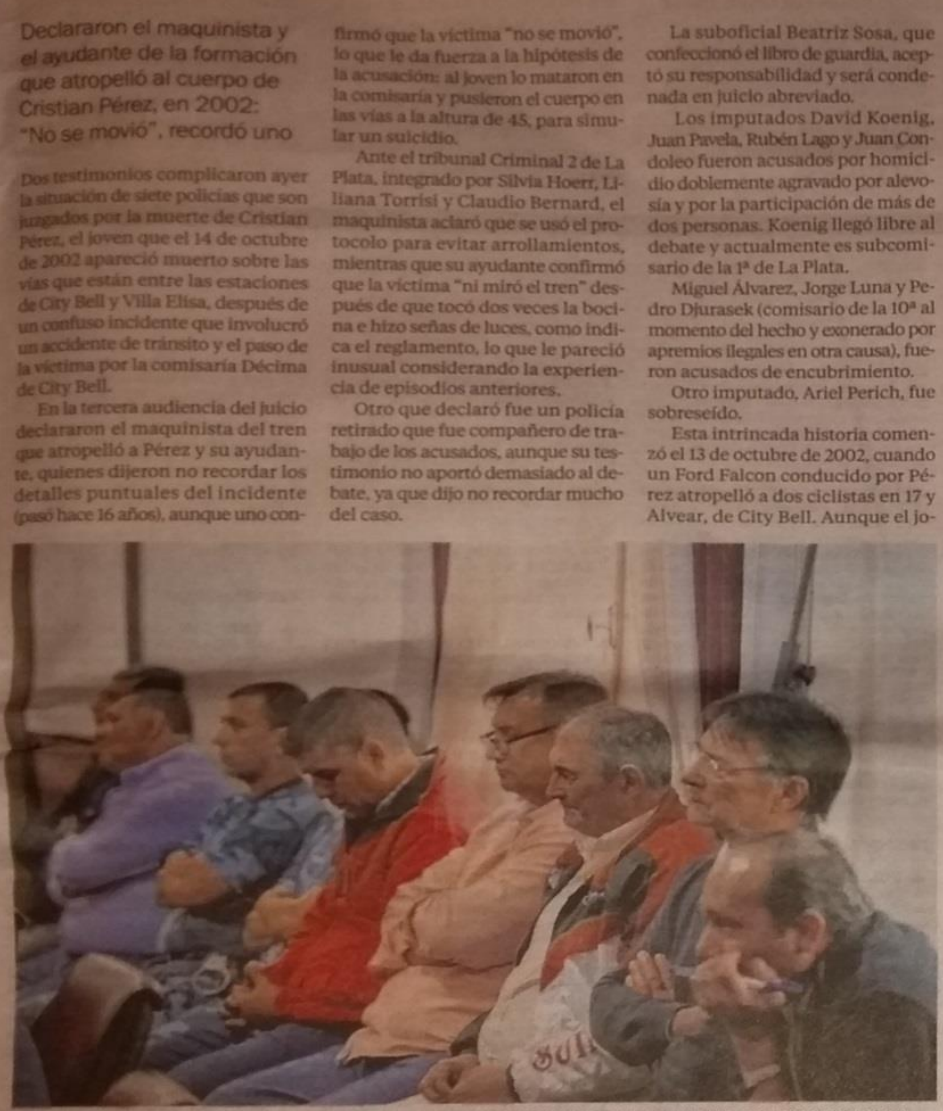

EN EL BANOUILO HAY SIETE POLCIAS, CUATRO ACUSADOS DEL HOMICIDIO Y TRES POR ENCUBRIMIENTO / ROBERTO ACOSTA

UN ADOLESCENTE EN EL BANQUILLOO

La pesquisa y una cámara de vigilancia, en el juicio por el crimen de Abril

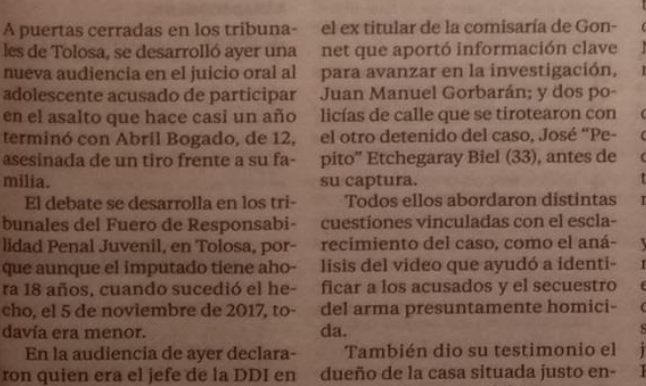
quel momento. Pedro Beltrame; oria del video registrado por las cáe 510 entre 11 y 12 , cuando regre-

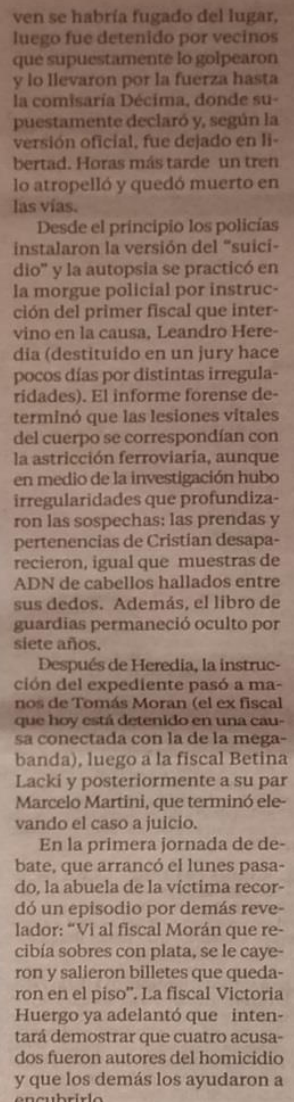
encubrirlo.

yas cámaras grabaron la secuencia completa, quien se límitó a confirmar que ese material era original y to de los pesquisas. Otro testimonio importante fue el del primer médico pediatra que asistió a Abril en el hospital de Gonnet: recordó que la menor ingresó con un paro cardiorrespiratorio y en estado critico, por lo que fue estabilizada y derivada de urgencia al hospital de Niños, donde murí a las pocas ho-

Fuentes judiciales confirmaron que las declaraciones fueron "coincidentes, en términos generales" $\mathrm{y}$ destacaron la contundencia probamaras de seguridad.

El hecho ocurrió en 510 entre 11 12, cuando Cristian Bogado Scenen la entrada de garaje de su casa unto con su esposa Laun, Jugo y sus dos hijes. Abril iba en lasiento trasero del lado del acom- pañante -detrás del abuelo y al ado de la mamá, que llevaba a se colocaron a ambos lados del uto y uno, del lado de Abril, disparó hacia adentro. La chica recibió un tiro en la frente.

Las cámaras registraron esa via, con uno de los ladrones cono a un conductor de un Volkswagen Golf que logró escapar. El ex convicto José "Pepito" tchegaray Biel (quien cumplió condena por robo y tentativa de er el disp) fue acusado de haecha aún no definida.

$\mathrm{El}$ adolescente llegó a juicio cusado de "robo en grado de tentativa en concurso real y homicidio en ocasion de robo, en nal conformado por los jueces Juan Carlos Estrada, Florencia Eutierrez y Juan Pablo Masi. con los familiares de Abril. secuencia, pero también la pre-

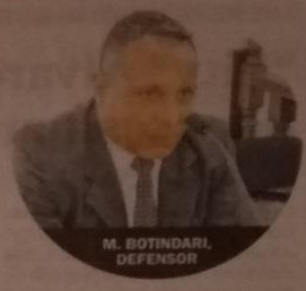

Declararon inimputable al joven que atacó a 4 vecinos

Nicolás Waldemar Pollice (28), el joven que hace poco más de dos personas en Berisso, fue declarado inimputable por la fueza Maria Isabel Martiare
Criminal V.

En el veredicto absolutorio, ia jueza dispuso la aplicación de una Pollice a cumplir "en el ảmbito de del Servicio Penitenciario Bona rense, con los resguardos y tratamientos sugeridos", para que "se le quístrico, terapéutico y farmacolo quiarrico, terapeutico y farmacolodicó en la resolución a la que acceste diario. hasta que -sea viable el alta médisidad del causante para si $y / 0$ terceros, cesando en esa oportunidad la intervencion del presente fuero penal, agrega el falio, aclarando go de manera permanente bajo la órbita de un juzgado de familin competente.

INESPERADO

El hecho ocurrió el 3 de septiembre de 2016 en los alrededores de 9 entre 162 y 163 de Berisso, cuando el muchacho, que no tenía antecedentes psiquiátricos, atacó a cuatro vecinos con un cuchillo, sin mo-

Una de las pocas personas que intentó ayudarlo fue una mujer de 56 años que recibio entre 15 y 20 cortes y tuvo que ser internada en
el hospital Larrain, igual que un ju-
bilado de 89 años.

Los otros dos heridos sufrieron heridas leves.

En la primera audiencia del juifensores particulares de Pollice. Marcelo Botindari y Santiago Irisa. rri, coincidieron en que el acusado fue el autor de los ataques, como en el hecho de que al momento de ejecutarlos el joven estaba "bajo el padecimiento de una psicopatologia con criterio suficiente para conformar un cuadro de caracteristicas psicopáticas retrospectivas". Dicho en otras paiabras, presentaba una alteración morbosa de sus facultades mentales, que ie impidio comprender ia criminalidad de sus actos". concluyó la justicia en vir tud de los informes periciales. Nicolás permanece detenido en la Unidad Penitenciaria 34 de $M$ elnos con pato, que alberga a inter- 


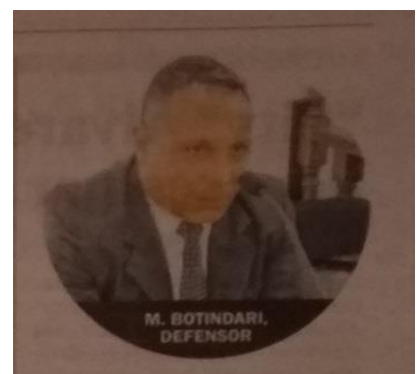

EN BERISSO

Declararon

inimputable al

joven que atacó a 4 vecinos

Nicolás Waidemar Pollice (28), el oven que hace poco más de dos años atacó a cuchilladas a cuatro personas en Berisso, fue declarado inimputable por la jueza Maria Isabel Martiarena, del Tribunal Oral y Criminal V.

En el veredicto absolutorio, 12 jueza dispuso la aplicación de una medida de seguridad curativa para Pollice a cumplir "en el ámbito de del Servicio Penitenciario Bonaerense, con los resguardos y tratemientos sugeridos", pare que "se le brinde tratamiento psicolónico, psiquí́stico, terapéutico y farmacoloquiáfrico, teraptutico y farmacologico de me, dicó en la reste diario.

Esa medida se implementar hasta que "sea via ca y la desaparición de la peligrosidad del causante para sí y/o terceros, cesando en esa oportunidad la intervención del presente fuero penal", agrega el fallo, aclarando penel agrega el fallo, aclarando que de manera permanente, bajo petente.

INESPERADO

El hecho ocurrió el 3 de septiembre de 2016 en los alrededores de 9 entre 162 y 163 de Berisso, cuando el muchacho, que no tenía antecedentes psiquiátricos, atacó a cuatro vecinos con un cuchillo, sin motivos.

Una de las pocas personas que intentó ayudarlo fue una mujer de 56 años que recibió entre 15 y 20 cortes y tuvo que ser internada en el hospital Larrain, igual que un juel hospital Larrain, ig

bilado de 89 años.
Los otros dos heridos sufrieron Los otros dos
heridas leves.

En la primera audiencia del juicio la fiscal Leila Aguilar y los defensores particulares de Pollice, Marcelo Botindari y Santiago Irisarri, coincidieron en que el acusado fue el autor de los ataques, como en el hecho de que al momento de ejecutarlos el joven estaba "bajo el padecimiento de una psicopatologia con criterio suficiente para conformar un cuadro de característiformar un cuadro de caracteristicas psicopáticas retrospectivas". Dicho en otras palabras, presentab. una alteración morbosa de sus ia"comprender la criminalidad de sus actos", concluyo la justicia en virtud de los informes periciales.

Nicolás permanece detenido en la Unidad Penitenciaria 34 de Melchor Pomero, que alberga a internos con patologfas pstquitíricas. 
Diario: El Día

Fecha de edición: 2 de noviembre de 2018 (misma nota que para la versión digital)

Volanta: ---

Título: Declararon inimputable al joven que atacó a 4 vecinos

Espacio que ocupa la nota: un cuarto de página, sector derecho de la hoja, en numeración impar.

Bajada: misma que para la versión digital

Firma

Imágenes: Foto a color de uno de los abogados defensores de Nicolás.

Epígrafe: M. Botinardi, defensor.

Destacado:

Subnotas: ---

Tema que aborda el artículo: misma nota que en la versión digital.

Análisis e interrogantes del abordaje mediático del caso del "loco del cuchillo"

Luego de realizar el rastreo del caso seleccionado para el análisis de tratamiento y construcción mediática de una noticia, puede llegarse a varias conclusiones.

La primera de ellas es la fragilidad de las fuentes utilizadas por los medios analizados para la redacción de los artículos periodísticos. En su gran mayoría se privilegia la voz de las víctimas y testigos, pero sin profundizar demasiado. Por más que las afirmaciones de las personas consultadas sean "porque les dijeron" o "porque lo suponen", esa información igualmente forma parte de la noticia, como si fuesen verdades; pero asegurándose de encomillar las frases, para que, en caso de no poder corroborarse esos dichos con la realidad, se 
desresponsabilice al medio en tanto no es algo que ellos afirman, sino el entrevistado.

Convertir a las víctimas en "corresponsales" de los medios, implica restar objetividad a la publicación, dado que esa información que se pone a circular no sólo es subjetiva, sino parcial. Al respecto señala Villarruel (2014):

Nosotros los periodistas, debemos tratar de investigar o llevar al público la verdad de los hechos, no nuestro pesar por el dolor de las víctimas. Sin embargo, se cae fácilmente en el horror periodístico de opinar desde el lugar de la víctima. Al hacerlo, se reduce a la simpleza de necesitar culpables inmediatos, cuando el derrotero de una causa penal no funciona de esa manera (pág. 31).

Puede advertirse que no hay un acercamiento del medio a la zona de los hechos, en tanto las fotos que aparecen en las publicaciones son siempre las mismas, y en algunos casos, de cámaras de seguridad.

Es llamativo cómo para el diario El Día, una noticia que fue nota de tapa, ocupando un lugar central y estratégico en la primera plana, pasados cinco días de la primera publicación, no vuelve a ser mencionado hasta noviembre de 2018, momento en el que finalmente se le declara la inimputabilidad a Nicolás por el episodio del 2 de septiembre de 2016. Esto daría cuenta de que, para ese medio, el caso del "acuchillador de Berisso" dejó de ser noticia en cuanto fue trasladado a un neuropsiquiátrico y la última víctima fue dada de alta y retorna a la escena ante la novedad judicial.

Al momento de tener que emitir información sobre la situación procesal del joven detenido, se encuentra que aparecen datos mencionados sin dar cuenta de la fuente consultada, utilizándose términos jurídicos de manera concluyente, afirmándose hechos que, en el seguimiento del caso, resultan contradictorios entre sí. Poco pareciera importar la veracidad o la pertinencia del uso de ciertos conceptos o nominaciones a la hora de comunicar. 
Esto pudo advertirse sobre todo al encontrar una contradicción desde el punto de vista jurídico entre la supuesta absolución por declaración de inimputabilidad del joven, y el llamado a juicio para fines de este año. Tal lo desarrollado en capítulos precedentes, si efectivamente se hubiese dado lo primero (absolución por declaración de inimputabilidad), no debiera llevarse al sujeto a juicio (porque no sería capaz de responder por la acción cometida por no comprender al momento del hecho la criminalidad de ésta). Esto llevó a realizar algunas averiguaciones al respecto, pudiendo encontrar que lo que los medios efectivamente informaron, no se correspondía con lo que ocurría en la causa. Una "verdad a medias" que se terminó convirtiendo en información falsa. Lo interesante en este punto es que, a menos que exista un conocimiento por parte del lector respecto al tratamiento jurídico de una causa, es poco probable que estas contradicciones pudiesen ser advertidas. Allí radica la ética del periodista de intentar informar lo más certeramente posible a la población, de lo contrario esta "deformación" en la comunicación, no hace más que construir realidades que luego son reproducidas por los receptores. Pudiendo repetir, por ejemplo, que una persona con declaración de inimputabilidad por una acción cometida es llevada juicio.

En las averiguaciones que se pudieron realizar por fuera del tratamiento mediático -consultando a profesionales que cuentan con información de primera mano sobre el caso-, pudo saberse que Nicolás se encuentra en la Unidad 34 de Melchor Romero -La Plata- desde momentos posteriores a su detención, y continúa allí.

En la presentación que se hizo en primera instancia frente al juez de garantías, tanto la defensa como la fiscalía -a partir de las conclusiones arrojadas por las pericias profesionales- solicitaron la absolución por inimputabilidad. Esta solicitud fue desestimada por el juez. De ese modo, se abre el proceso judicial contra Nicolás, en donde interviene otro fiscal, que es quien realiza el llamado a juicio.

Esta información adicional que no ha salido publicada en ningún medio no resultó difícil de conseguir, si el medio verdaderamente hubiese tenido la 
intención de realizar una investigación que permitiera difundir datos precisos y correctos, hubiese alcanzado con comunicarse con fuentes de primera mano, cercanas al expediente. A quien escribe este trabajo, sólo le costó realizar un llamado telefónico.

En el último artículo que aparece sobre el caso, justo al cierre de la redacción de esta tesis, se presentan novedades en relación con la situación judicial de Nicolás, donde se da cuenta de la declaración de inimputabilidad por el hecho del 3 de septiembre de 2016. En las frases que allí se retoman de la resolución judicial en forma textual, se advierten aspectos que han sido abordados a lo largo de este trabajo en relación con el tratamiento de las personas con padecimiento mental que han cometido una acción antijurídica y el desconocimiento u olvido de la ley de salud mental a la hora de tomar una decisión respecto al destino de los sujetos.

Allí se menciona que la jueza ha decidido la aplicación de medida de seguridad "curativa" a cumplirse en el "Servicio Penitenciario Bonaerense", más precisamente en la Unidad Penitenciaria N. ${ }^{\circ} 34$ de Melchor Romero, lugar en el cual se encuentra detenido el joven desde el momento del hecho; se hace referencia a que la misma es para que reciba "tratamiento psicológico, psiquiátrico, terapéutico y farmacológico de manera permanente", demostrándose desconocimiento de lo normado en la ley de salud mental, la cual indica que el abordaje terapéutico de las personas con padecimiento mental deben ser por medio de un equipo interdisciplinario -no diversos tratamientos simultáneos, lo cual constituiría multidisciplinar-, atendiendo a la integralidad del sujeto, que el dispositivo privilegiado para trabajar debe ser el más cercano a la comunidad, y no el encierro o internación, a menos de encontrarse una situación de riesgo cierto e inminente para sí o para terceros cierto remite a certeza, inminente, a la inmediatez, ahora-.

Respecto a lo que menciona en relación con el tratamiento farmacológico, la resolución dice "tratamiento farmacológico de manera permanente", cuando la ley estipula que la medicación debe ser sólo en casos de considerarse necesario el suministro de ésta, con revisión periódica por parte del equipo 
interdisciplinario que atiende al sujeto y procurando el retiro la misma, en caso de ser posible, del todo.

Respecto a la posibilidad de libertad de Nicolás, se hace mención de que la medida de seguridad será implementada hasta que "sea viable el alta médica y la desaparición de la peligrosidad del causante para sí y/o terceros, cesando en esa oportunidad la intervención del presente fuero penal" y pasando a la órbita del juzgado de familia.

En esto puede advertirse cómo el concepto de peligrosidad sigue siendo lo que dirige la determinación por parte de la jueza, primando la segregación y aislamiento, resultando muy difícil poder anticipar en qué momento el sujeto podrá volver a vivir en comunidad, pudiendo ser que su tiempo de reclusión sea mayor que el que le hubiesen otorgado de haber sido encontrado imputable y culpable de la acción de la que se lo acusa.

El diario El Día vuelve a tomar la noticia en tanto lo que aparece como novedad es la confirmación en relación con la "locura" del sujeto y con información en la que se resalta solamente lo referido a la medida de seguridad a aplicar, un recorte que da cuenta de la intencionalidad editorial respecto al caso. Nada se dice respecto de cómo ha avanzado -o no- el tratamiento del sujeto desde su traslado a la Unidad Penitenciaria en septiembre de 2016 a la fecha. 


\section{CONCLUSIONES}

Palabras clave: peligrosidad, hegemonía, criminología, medios

Al comenzar con este trabajo se partió de la premisa de que los medios de comunicación no son entes abstractos ni ingenuos, sino que son actores políticos, económicos, empresariales, sociales, educativos y culturales que influyen en los imaginarios sociales y construyen sentidos. También se señaló que éstos se encuentran en un contexto social y cultural en el que se producen y enmarcan. Por otra parte, los medios de comunicación no sólo informan sobre los hechos que acontecen, sino que interpretan esos hechos y los convierten en noticiables.

Como actores de poder, los medios de comunicación reproducen el statu quo hegemónico porque son parte de éste. Esto lo hacen a partir de generar un consentimiento aparentemente voluntario de las clases menos favorecidas para con el sistema a través de la construcción de un sentido común, que lo que hará es seguir sosteniendo esa subordinación, es la reproducción del sistema de dominación. El sentido común lo que produce es que todas las personas piensen igual sobre los temas esenciales de una sociedad, estableciendo una disputa entre el pensamiento autónomo de los sujetos y el pensamiento del poder. El poder mediático triunfa cuando logra imponer el sentido común como pensamiento de todos.

Se pudo situar también que la subjetividad -social o singular- es el resultado de la puesta en práctica de discursos que construyen una cultura determinada, de la historia y de la sociedad, por lo que no se la puede comprender sin abordar el contexto de surgimiento. La producción de subjetividad estará sujeta a las variables contextuales propias de una sociedad y de un momento histórico social particular.

En esta construcción de subjetividades, juegan un papel importante las normas sociales, las leyes, cuya función es la regulación los vínculos y los lazos en la sociedad, lo que se constituye como lo "socialmente aceptable" - 
normas, pautas culturales-, y que tampoco no son ni neutrales ni objetivas, sino que tienen como origen los intereses de quienes ejercen el poder social, y que buscan mantener esos espacios de poder. Allí la clave se encuentra en producir una naturalización de las pautas con su incorporación al sentido común compartido. En esto, los medios de comunicación, con su función reproductora, tienen un papel fundamental.

El poder, al tener el poder de lo comunicacional, difunde sobre la población un discurso y un pensamiento que expresa los intereses de la clase dominante: se difunde lo que esos sectores quieren o necesitan que el resto de la población piense, para que actúe en consecuencia, siendo funcional a la reproducción de un statu quo. El modo en el que esto se lleva a cabo es mediante la producción y reproducción de un "sentido común" que tiene la particularidad de ser el pensamiento del poder.

Los medios son actores activos de transformaciones sociales, toman una porción parcializada de la realidad y generan verdades a partir de sus propios intereses ideológicos $\mathrm{y}$, de este modo, construyen percepciones en la sociedad. Se trata de la construcción, selección y jerarquización de la información en tanto los medios son quienes legitiman la palabra de unos por sobre la de otros, se selecciona qué se difunde y qué se oculta es una decisión subjetiva, y se hace en forma intencional.

La selección, jerarquización e intencionalidad editorial, que forman parte de la construcción de una noticia, constituyen decisiones políticas del medio.

Esto pudo observarse en el desarrollo del trabajo al abordar conceptualmente la "criminología mediática", que lo que hace es crear una realidad -una entre muchas posibles- y presentarla como "la" realidad, donde aparecen enfrentadas las "personas decentes" con el grupo de "criminales" los cuales son identificados por el estereotipo que permite sostener esa distinción.

Pero allí también se dijo que para que esta diferenciación perdure en el tiempo y resulte creíble, no queda otra opción más que "inflar" las características negativas de quien porta el estereotipo sobre la base del 
peligrosismo y es allí donde el concepto de peligro se une al de seguridad, reduciendo a la inseguridad solamente a situaciones que tienen que ver con la violencia del robo.

A la par de la reproducción de noticias que apuntan a aterrar a la población, aparece la construcción del estereotipo de quien es el "encargado" de sembrar el miedo, es decir, el estereotipo del "delincuente".

Todas las sociedades, históricamente, se han creado un estereotipo de "delincuente". En la actualidad, es el del joven o menor de edad, de barrios carenciados, con ciertos rasgos físicos que se exacerban en la transmisión de la imagen como por ejemplo ser morocho, cierto modo de vestir, como el usar viseras, piercings, tatuajes, camperas holgadas. De este modo, se termina homologando pobreza con peligrosidad.

El estereotipo asignado al sujeto que será indicado como el potencial delincuente, se pudo concluir desarrollar que sostiene en una premisa biologicista, dado que mientras porte el estereotipo -a lo largo de toda la vida si no cambia el chivo emisario de la sociedad- el sujeto seguirá siendo peligroso, por lo que cualquier intento de respeto de sus garantías procesales será tomado por la sociedad como una aberración de la justicia que falla en detrimento de la "sociedad" -porque quienes portan el estereotipo no son considerados "gente como uno", sino que son excluidos y marginados-.

Al mismo tiempo, la sociedad comienza a solicitar penas más duras, baja en la edad de imputabilidad, ejerciendo presión que, en ocasiones, termina modificando las legislaciones. Es por esto por lo que los medios de comunicación pueden considerarse segmentos del sistema penal, porque luego con esas leyes todos somos regulados, además de que ese "empuje" a la asunción de un rol previamente establecido y reproducido por los medios de comunicación es lo que hace al sujeto susceptible de ser captado por el sistema penal, es lo que R. Zaffaroni (1998) llama la "vulnerabilidad sociopenal". 
Esta construcción que realizan los medios de comunicación se caracteriza por la deformación de la realidad, en donde se enfrentan dos bandos, los buenos y los malos, construyendo la certeza de que el único modo de hacer algo con los conflictos tiene que ver con la punición y la violencia. Esta construcción es posible en tanto pensemos a los medios como mediadores, como actores políticos, sociales, culturales y económicos.

Si bien en la actualidad se asiste a momentos de fuerte presencia mediática y tecnológica en la vida de las personas, siempre los medios de comunicación y la criminología han tenido una relación estrecha, donde los primeros ayudan a legitimar a la segunda y justificar una modalidad de control social punitivo-represivo institucionalizado, desde un modelo reproductivista acrítico.

A lo largo del desarrollo de este trabajo también se pudo arribar a la conclusión de que en la actualidad, si bien la postura peligrosista ha tenido sus críticas y detractores -sobre todo a partir de la década de 1940-, lo cierto es que en las prácticas, sigue imperando el positivismo criminológico italiano en el Sistema Penal argentino, en tanto se sigue basando en la selección, estigmatización y criminalización de ciertas porciones de la población que son quienes son captadas por el sistema penal, siendo estos mecanismos funcionales a la lógica reproductivista del mismo.

En lo que tiene que ver con el tema particular del tratamiento del padecimiento mental en ocasión de la realización de una acción antijurídica, se pudo situar a la "locura" como una categoría producto de un contexto, a la cual es posible darle fecha de nacimiento $\mathrm{y}$, por medio de un estudio bibliográfico, se dio cuenta de que históricamente el tratamiento de la salud mental ha sido distinto, lo cual abona la afirmación precedente.

Los medios de comunicación contribuyen a la creación y reproducción del estereotipo del "loco peligroso" en los casos de sujetos con padecimiento mental que realizan alguna acción antijurídica en una situación en la que no se encuentran en posibilidades de comprender la criminalidad del hecho. La 
información que se brinda resulta en la mayoría de los casos parcializada y fala de objetividad, con errores en el tratamiento de los procedimientos jurídicos. Esto se ve acompañado desde lo judicial en tanto en la actualidad puede afirmarse que prima el paradigma humanista que intenta deslindar al sujeto del estereotipo del loco criminal, mediante un cambio de concepción que no reduce al individuo a su padecimiento, pero en las prácticas sigue resistiendo el positivismo, privilegiándose la aplicación de medidas de seguridad en encierro punitivo por sobre medidas tratamentales en comunidad o en sistemas ambulatorios.

Si bien la ley de salud mental no menciona la situación de las personas con padecimiento mental que se encuentran encerradas bajo medida de seguridad en instituciones penitenciarias, desde el derecho, cuando acontece una situación de acción antijurídica cometida por un sujeto que es considerado inimputable, lo que debiera primar es abordarlo desde la ley de salud mental.

De todo el desarrollo precedente surge que, en la actualidad, se sigue utilizando el concepto de peligrosidad tal como lo presentara el positivismo italiano de Lombroso, Ferri y Garófalo; observándose sobre todo en los casos en los que se aplican medidas de seguridad a personas con padecimiento mental que han cometido algún tipo de acción antijurídica.

La privación de libertad en Unidades Penitenciarias Psiquiátricas sigue siendo la medida privilegiada, aun encontrándose vigente la ley Nacional de Salud Mental N. ${ }^{\circ}$ 26.657, y teniendo las recomendaciones de CONISMA (Comisión Interministerial en Políticas de Salud Mental y Adicciones) ${ }^{x x x v i}$ que indican que las medidas que deben utilizarse siempre deben cumplirse en instituciones de salud; así, el "tratamiento" que recibe el sujeto es o bien medicalización o bien aislamiento, cuando no una combinación de ambos, entrando en los términos de la "eliminación" de lo social.

La Ley penal tiene la característica particular de que se aplica una vez que se ha cometido un delito; es por esto que puede sostenerse -luego de todo lo que se ha desarrollado hasta aquí- que la categoría de "peligrosidad" iría 
contra derecho, ya que se basa, sobre todo en la predicción; y, bajo una premisa "preventiva", pone en juego "medidas de seguridad", que nunca son ante un riesgo para sí mismo, sino para terceros: ¿peligroso para quién? Para el orden social.

La aplicación del concepto "peligrosidad" para indicar medidas de seguridad en personas con padecimiento mental va contra derecho pensado en términos democráticos y se constituye como la piedra angular de un Derecho Penal peligrosista y subjetivo.

Esto se pone en relación con lo que sostiene Ziffer (2006) cuando plantea la imposibilidad de legitimar la privación de libertad de cualquier persona basada en una sospecha, cuyo único objetivo sería paliar el temor de la sociedad hacia determinadas personas.

Si aquel que comete un delito es una persona que porta un padecimiento mental se asiste, en la mayoría de los casos, a tal confusión que tiene por punto de llegada la equiparación de padecimiento mental con peligrosidad.

Los medios de comunicación contribuyen a la construcción, difusión y perpetuación del estereotipo del "peligroso", ya sea del "loco peligroso" o del peligroso de moda del momento (que bien puede ser el "pibe chorro" en época electoral, momento en el que más se pide la baja de edad de imputabilidad).

En el análisis que se ha realizado sobre el seguimiento de una noticia periodística, ha quedado demostrado cómo los medios que se han estudiado realizan una selección, jerarquización, construcción y tratamiento de la información en el que se muestra cómo se judicializa al sujeto, pero dejando de lado que es un sujeto de derecho. Lo que queda en evidencia es que lejos de interesarle al medio informar a la población sobre determinado hecho, lo que le importa es la venta de un producto, sin tener en cuenta las repercusiones que sobre los sujetos tenga el tratamiento realizado y difundido. 
La imposición de la etiqueta "el loco del cuchillo", atribuida a una persona de la cual se revelan sus datos personales, constituye una situación sin retorno, afectando directamente el honor de ésta (Villarruel, 2014, pág. 35).

Esta falta en el sentido de la ética de la labor periodística y de los editores responsables de decidir qué se publica, cómo y dónde, el valor de las palabras utilizadas, la adjetivación, entre otras cuestiones que hacen al texto y al paratexto, son las que permiten situar a los medios de comunicación como agentes de criminalización secundaria, en tanto seleccionan un hecho a ser difundido -sin importar, ya se ha dicho, la veracidad del contenido a publicar-, siempre desde una posición parcial y subjetiva -privilegiando el relato y palabra de las víctimas- y durante el tiempo que el medio considere que es rentable, luego la historia cae en el olvido, pero no los imaginarios que se han construido socialmente en el sentido común, los cuales siguen teniendo efecto y se seguirán reproduciendo.

Es el pasaje de los medios a las mediaciones, que aborda Martín Jesús Barbero (1987), quien sostiene que la información pasa a estar mediada por la ideología que conforma la intencionalidad editorial del medio, siempre investida del pensamiento hegemónico que es necesario sostener en la lógica reproductivista del neoliberalismo. Es la construcción de un sentido común que divide a la sociedad al generar odio, discriminación, divisiones, la noción del "enemigo interno" de la seguridad ciudadana. En el caso analizado y desarrollado en este trabajo, por medio de la criminalización mediática.

Históricamente los imaginarios sociales en relación con la noción de peligrosidad se han desarrollado y sostenido de esa manera. Cambia el chivo expiatorio, la noción de peligrosidad sigue resistiendo a pesar del paso del tiempo.

Es por todo esto que se hace necesario comenzar a pensar en la construcción de un contra discurso que ponga en "primera plana" el accionar de los medios de comunicación tal como se lo ha descrito en este trabajo: carente de ingenuidad y cargado de ideología hegemónica. Sólo promoviendo y 
fomentando un posicionamiento crítico en la lectura de la "información" que producen y reproducen los medios, existe la posibilidad de alcanzar una mayor libertad en el pensamiento y en la vida, al estilo de lo que se planteara previamente respecto de dejar de ser sujetos sujetados, y por ende moldeados.

Si bien los medios no ocultan su ideología, tampoco la explicitan, lo cual hace que no sea develable por todos, ya que no se encuentra a simple vista para los usuarios de los medios.

Es necesario realizar una operación de deconstrucción de la posición de receptor para hacer el movimiento que permita visualizar la construcción de imaginarios y su repercusión en las subjetividades. En esta operación será fundamentar indagar los "por qué" de este accionar de los medios, cuáles son las ideologías de base, y cuáles los objetivos que persiguen (la masificación, el control de la población, la manipulación, la división de la población para perpetuar modelos de control social punitivo-represivos).

El modo privilegiado para poder generar y sostener un contra discurso en materia de criminología, tiene que ver con fortalecer al Estado. En esto será primordial fomentar lazos sociales que sean más estables, que tiendan a la inclusión y que permita la desestigmatización del diferente, del pobre, del marginado. El otro no es más que un semejante vulnerable.

Si el Estado y la población como parte integrante, lograran tomar conciencia de la corresponsabilidad implícita en el haber dejado avanzar el proceso de vulnerabilidad de los sujetos de sectores marginales y comprendieran que la seguridad también tiene que ver con tener el mayor acceso posible a los derechos, sería más sencillo poder vislumbrar que el otro no es mi enemigo, sino un semejante que no ha tenido las mismas posibilidades. La estigmatización, la exclusión que ésta conlleva y el castigo violento no se aproximan en lo más mínimo a una solución de la criminalidad, sino que más bien pareciera ocurrir todo lo contrario.

Como se menciona a lo largo de este trabajo, no puede plantearse la posibilidad de un cambio o de reversión de la situación actual desde un 
alejamiento o abandono del uso de medios, sino todo lo contrario: se debe utilizar a los propios medios para comenzar a pensar en un cambio que se produzca "desde adentro". Una aliada fundamental en este sentido será la educación. Pero no la educación en tanto mera transmisión de conocimientos o saberes conceptuales, sino una educación que permita a las personas posicionarse críticamente frente a los conocimientos, los conceptos y puedan contrastarlos con la realidad, una realidad vivida y no contada por los medios.

Esto implicaría no solamente una modificación en los contenidos y estrategias curriculares, sino también una exigencia en la formación de los docentes para ser también promotores de ese cambio.

"Libres son quienes crean, no quienes copian; libres son quienes piensan, no quienes obedecen. Enseñar es enseñar a dudar". Eduardo Galeano. 


\section{REFERENCIAS BIBLIOGRÁFICAS}

AA.VV. (2007) Periodismo de calidad: debates y desafíos. Buenos Aires: FOPEA, La Crujía.

Alagia, A. (2013) Hacer sufrir. Buenos Aires: Ediar.

Álvarez Uría, Fernando. Sociologías de la cárcel. Buenos Aires: Revista Archipiélago $\mathrm{N}^{\circ} 3$.

Aniyar de Castro, L. (1987) Conocimiento y orden social: Criminología como legitimación y Criminología de la liberación. Maracaibo: Editorial de la Universidad de Zulía.

Aniyar de Castro. L. (2010) Criminología de los Derechos Humanos. Criminología axiológica como política criminal. Buenos Aires: Ed. Del Puerto.

Aniyar de Castro, L.; Codino, R. (2013) Manual de criminología sociopolítica. Buenos Aires: Ediar.

Baratta, Alessandro. (1990) Resocialización o control social. Ponencia presentada en el seminario "Criminología crítica y sistemapenal", organizado por Comisión Andina Juristas y la Comisión Episcopalde Acción Social, en Lima, del 17 al 21 de Septiembre de 1990.

Baratta, A. (1982) "Observaciones sobre las funciones de la cárcel en la producción de relaciones sociales de desigualdad", en Nuevo Foro Penal. Bogotá: Temis.

Baratta, A. (1987) "Principios de derecho penal mínimo (para una teoría de los derechos humanos como objeto y límite de la ley penal)", en Doctrina Penal, año $10, N^{\circ} 37$ a 40, Depalma, págs. 623 a 650.

Barbero, M. (2010) "Notas para hacer memoria de la investigación cultural latinoamericana" en En torno a los estudios culturales. Buenos Aires: CLACSO

Beccaria, C. (2005) De los delitos y de las penas. Capital Federal: Ediciones Libertador. 
Berger y Luckman. (2008) La construcción social de la realidad. Buenos Aires: Amorrortu Editores.

Bernazza, C. (2013) 2003-2013 Diez Años del Proyecto Nacional. Las leyes que cambiaron la(s) historia(s). La Plata: EPC-Edulp.

Blázquez, V.; Ghea, M. E.; Vialey, P. (2009) El valor de las palabras ¿A qué se refiere el concepto de construcción, selección y jerarquización de la información? Ficha de cátedra Taller de Análisis de la Información. La Plata: Facultad de Periodismo y Comunicación Social.

Bourdieu, P. (1997) Sobre la televisión. Buenos Aires: Editorial Anagrama.

Cabello, V. (1963) "Peligrosidad penal de los enfermos mentales. La fórmula de los cinco elementos". En Revista La Ley. Argentina. v. 112; p 876-882.

Camargo, L. (2005) Encrucijadas del campo psi-jurídico. Buenos Aires: Ed. Letra Viva.

Castells, M. (2009) Comunicación, poder y contrapoder en la sociedad en red. Los medios y la política. Buenos Aires: Revista Telos.

Chomsky, N. (Sin Fecha) 10 Estrategias de manipulación mediática. Recuperado de https://www.revistacomunicar.com/pdf/noam-chomsky-la$\underline{\text { manipulacion.pdf }}$

Chomsky, N (2007) Ilusiones necesarias. La Plata: Caronte ensayos.

Comité contra la Tortura (2013) Informe Anual. Recuperado en internet de: http://www.comisionporlamemoria.org/comite/informes/anuales/informe\%20201 3FINAL\%20b.pdf

Comité contra la Tortura-CELS (2012) Informe para el Subcomité de Prevención de la Tortura (ONU). Recuperado en internet de: http://www.comisionporlamemoria.org/comite/informes/internacionales/Informe \%20CCT-CELS-PBA-SPT-Marzo\%202012\%20Final.pdf. 
Cornejo, A. (1991) Los delitos del tráfico de estupefacientes. Capital Federal: Alfa Beta.

Creazzo, G. (2007) El positivismo criminológico italiano en la Argentina. Buenos Aires: Ediar.

De Foncuberta, M.; Borrat, H. (2006) Periódicos: sistemas complejos, narradores en interacción. Buenos Aires: Editorial La Crujía.

Degano, J. (2011) La responsabilidad precluida en el goce y en el tratamiento judicial. Buenos Aires: Letra Viva.

Di Nella, Yago -comp.- (2011) Psicología Forense y Derechos Humanos. Vol 2: El Sujeto, la ley y la Salud Mental. Buenos Aires: Koyatún.

Domínguez Lostaló, J. C. (1996) Diagnóstico de Vulnerabilidad Psicosocial. Ficha de Cátedra Psicología Forense. La Plata: UNLP.

Domínguez Lostaló, J. C. (1997) Vulnerabilidad. Aportes a la discusión de un concepto que rompe un paradigma Ficha de Cátedra. Psicología Forense. La Plata: UNLP.

Domínguez Lostaló, J. C.; Facio Fernández, T. Administración de justicia: Política y burocracia. Ficha de Cátedra Psicología Forense. La Plata: UNLP.

Domínguez Lostaló, J. C. (1999) Los pibes marginados. La Plata: Cuadernos Cuadernos del Caleuche.

Dorfman y Mattelart (1972) Para leer al Pato Donald. Buenos Aires: Siglo XXI Editores.

Elbert, C. A. (1998) Manual Básico de Criminología. Buenos Aires: Eudeba

Elíades, A. (2012) El derecho de rectificación o respuesta en la jurisprudencia de la Corte Suprema de Justicia de la Nación. La Plata: Facultad de Periodismo y Comunicación Social.

Fallo Gramajo SCJN sobre Inconstitucionalidad del art. 52. 
Faraone, S. y A. Valero (2012) Dilemas en Salud Mental. Sustitución de lógicas manicomiales. Buenos Aires: Ed. Madres de Plaza de Mayo.

Feinman, J.P. (2013) Filosofía política del poder mediático. Buenos Aires: Editorial Planeta.

Foucault, M. (2008) El orden del discurso. Buenos Aires: Fabula Tusquets Editores.

Foucault, M. (1980) La Verdad y las Formas Jurídicas. Buenos Aires: Gedisa.

Foucault, M. (2008) Vigilar y Castigar. Buenos Aires: Siglo XXI Editores.

Foucault, M. (2010) Defender la sociedad. Buenos Aires: Fondo de cultura económica.

Foucault, M. (2015) Historia de la locura en la época clásica. México: Fondo de cultura económica.

Freud, S. (2007) Obras Completas. Buenos Aires: Amorrortu Ediciones.

Freud, S. (1991) Tótem y Tabú. Buenos Aires: Amorrortu.

Fucito, F. (1999) Sociología del Derecho. Buenos Aires: Editorial Universidad.

García, A.; De Molina, P. (2008) Criminología. España: Ed. Tirant lo Blanch libros.

Ghea, E.; Vialey, P. (2010) Más allá de lo que publican los medios de comunicación. Ficha de cátedra Taller de Análisis de la Información. La Plata: Facultad de Periodismo y Comunicación Social.

Goffman, I. (1993) Internados. Buenos Aires: Editorial Amorrortu.

González, J. (2012) Los frentes culturales: culturas, mapas, poderes y luchas por las definiciones legítimas de los sentidos sociales de la vida. México: Universidad Autónoma de México. 
González, J. (2015) Los frentes culturales: culturas, mapas, poderes y luchas por las definiciones legítimas de los sentidos sociales de la vida. En Diá-logos de la Comunicación $N^{\circ} 26$.

Hall, S. (1996) "Codificar/Decodificar", en Culture, Media, Lenguaje. Working Papers in Cultural Studies, 1927-79.Londres Routledge \& The CCCS University of Birmingham. Traducción de Alejandra García Vargas. Material de uso interno de la cátedra de Sociología de la Comunicación, Facultad de Humanidades y Ciencias Sociales, Universidad Nacional de Jujuy.

Halperin, L. Crisis del sistema penitenciario ¿Qué crisis? Buenos Aires: Revista jurídica del centro de estudiantes.

Lacan, J. (1949) "El estadío del espejo como formador del yo (je) tal como se nos revela en la experiencia psicoanalítica." En Escritos 1. Buenos Aires: Editorial Siglo XXI.

Martínez, M. (2015) Derecho y Salud Mental. Historia del tratamiento jurídico de la locura en la República Argentina. Rosario: Editorial Juris.

Messuti, A. (2008) El tiempo como pena. Buenos Aires: Ediar.

Ministerio de Salud-Ministerio de Justicia y Derechos Humanos (2011) Programa Interministerial de Salud Mental Argentino (PRISMA). Serie 4: Presidencia de la Nación. 2011. Serie 4: Normativas. Buenos Aires: Dirección Nacional de Salud Mental y Adicciones

Moro, T. (1994) Utopía. Barcelona: Editorial Fontana.

Muñagorri Laguía, I (2006) "Políticas de seguridad, control preventivo y peligrosidad. La construcción del orden social seguritario". En Revista Delito y Sociedad. Programa de Estudios de Control Social (PECOS) del Instituto de Investigaciones Gino Germani y de la cátedra Delito y Sociedad: sociología del sistema penal. Buenos Aires: Facultad de Ciencias Sociales, UBA.

Niño, L. (sin fecha) Apuntes para una reflexión de los estudiantes de Derecho sobre la cárcel. La Plata: Revista jurídica del Centro de Estudiantes. 
Ruano y Ortiz, J. (2012) Historia y estado actual de la ciencia criminológica. Acatlam: UNAM

Ruiz- Funes, M. (2010) "Peligro, posibilidad, probabilidad". En Revista Jurídica La Ley, Argentina. v. 39, pág. 1029.

Ruiz-Funes, M. (2011) "Algunos conceptos sobre la peligrosidad". En Revista La Ley. Argentina. v. 3; p.943-950.

Saintout, F. (2011) "Los estudios socioculturales y la comunicación: un mapa desplazado". Revista. ALAIC, 8-9. Soriano, Jaume

Szasz, T. (2005). La fabricación de la locura. Barcelona: Editorial Kirós.

Soler, S. (1929) Exposición y crítica de la teoría del Estado Peligroso. Buenos Aires: Valerio Abeledo Editor.

Spitz, R. (1965) El primer año de vida del niño. Buenos Aires: Fondo de cultura económica.

Taylor, Walton y Yang (1997) La nueva Criminología. Buenos Aires: Editorial Amorrortu.

Villarruel, D. (2014) (In)justicia mediática. Buenos Aires: Editorial Sudamericana.

Williams, R. (2009) Marxismo y Literatura. Buenos Aires: Editorial Las cuarenta.

Zaffaroni, R. (2010) La cuestión criminal. Buenos Aires: Editorial Planeta.

Zaffaroni, R. (1998) En busca de las penas perdidas. Buenos Aires: Editorial Temis.

Zaffaroni R. (1993) Criminología: aproximación desde un margen. Buenos Aires: Editorial Temis.

Zaffaroni, R. (2011) La palabra de los muertos. Conferencias de criminología cautelar. Buenos Aires: EDIAR. 
Zaffaroni, R. (2005) "La criminología como curso", en En torno de la cuestión penal. Montevideo-Buenos Aires: Ed. BdeF.

Zaffaroni, R. (2010) "Larvas y semillas. Lineamientos para un replanteo criminológico", en Investigaciones $N^{0} 1$ año 2010. Instituto de investigaciones de la Corte Suprema de Justicia de la Nación. Dossier Genocidio y Lesa humanidad. Páginas $11-32$.

Zaffaroni, R. (2008) "Criminología y Psiquiatría. El trauma del primer encuentro". En Revista Digital de la Academia Bolivariana de Ciencias Jurídico Penales.

http://www.nunezdearco.com/ABCJP/R.D._2_zaffaroni.htm

Zaffaroni, R. (2012) La medida del castigo. Buenos Aires: Ediar.

Zaffaroni, R. (2009) El enemigo en el derecho penal. Buenos Aires: Ediar.

Zaffaroni, R.; Alagia, A.; Slokar, A. (2006) Manual de derecho penal. Parte general. Buenos Aires: Ediar.

Ziffer, P. (2006) "La idea de "peligrosidad" como factor de prevención especial. A propósito del fallo de la Corte Interamericana de Derechos Humanos en el Caso "Fermín Ramírez"." En Suplemento La Ley de Derecho Constitucional, pp. $45 / 56$.

\footnotetext{
i Perfil de la propuesta de la Maestría en Comunicación y Criminología Mediática, (2014), visible en http://www.perio.unlp.edu.ar/node/3138

Decreto Reglamentario Ley N. ${ }^{0} 26.657$ (15 de septiembre de 2017) visible en https://www.cels.org.ar/web/wp-content/uploads/2017/11/decreto-1.pdf

iii Unidad 34 - Melchor Romero, Calle 520 y 176 (CP 1903) - Melchor Romero. "Fue inaugurado el 14 de abril de 1999, en un principio como Sub Unidad de la existente Unidad 10 que funciona desde el año 1965, y siendo autónoma en el año 2001.

"Los internos alojados son los declarados inimputables, sobreseídos definitivamente por el artículo 34 inciso $1^{\circ}$ del Código Penal y procesados en estudio a la espera del dictamen pericial psiquiátrico cuya internación halla dispuesto el Juez competente. Además, son alojados internos que el Magistrado de este, ordena exámenes con el objeto de constatar o no la existencia de una posible enfermedad mental o ya cumpliendo su sentencia condenatoria presentan descompensación psiquiátrica y son derivados para su tratamiento.

"Funciona con el régimen cerrado, para sumar a la atención un criterio preventivo y asistencial para los cuadros agudos de patologías mentales que incluían la auto agresión y tentativa de suicidio. Con la aplicación de un tratamiento de abordaje múltiple e interdisciplinario".

Unidad 34 Melchor Romero (sin fecha), SPB. Recuperado de
} http://www.spb.gba.gov.ar/site/index.php/unidad-34-melchor-romero 
Ubicación: Google (Sin Fecha) Unidad 34 Melchor Romero. Disponible en

https://www.google.com/maps/place/Unidad+N\%C2\%BA+34/@-34.9594306,-

58.0554227,17z/data=!4m13!1 m7!3m6!1s0x95a2dcd48cee9041:0xd3cd656a67931ae1!2sCalle+179+\%26

+Avenida+520,+Melchor+Romero,+Buenos+Aires!3b1!8m2!3d-34.9582787!4d-

58.057032!3m4!1s0x95a2c2d573543d77:0x8294647597ef431d!8m2!3d-34.9607211!4d-58.0512857

iv Mapa de ubicación: Google (Sin Fecha) Neuropsiquiátrico Alejandro Korn. Disponible en https://www.google.com/search?client=firefox-b-

ab\&q=hospital+neuropsiqui\%C3\%A1trico+Alejandro+Korn\&npsic=0\&rflfq=1\&rlha=0\&rllag=-34952257,-

58050041,348\&tbm=Icl\&ved=0ahUKEwjEteio5f3bAhWCC5AKHUvcAN4QtgMIKQ\&tbs=Irf:!2m1!1e2!3sIAE, If:1, If ui:2\&rldoc=1\#rlfi=hd:;si:6697591528393389309;mv:!1m3!1d8669.29431172722!2d-

$58.04246569539794 ! 3 d-34.95293964381896 ! 3 m 2 ! 1$ i946!2i509!4f13.1

v Minuto uno. (9 de enero de 2016). Cómo fue la fuga de los hermanos Lanatta y Schillaci. Recuperado de https://www.minutouno.com/notas/1463522-minuto-minuto-como-fue-la-fuga-los-hermanos-lanatta-yschillaci

vi Infobae. (24 de octubre de 2016). María Eugenia Vidal removió a toda la cúpula del servicio penitenciario bonaerense. Recuperado en https://www.infobae.com/politica/2016/10/24/maria-eugeniavidal-removio-a-toda-la-cupula-del-servicio-penitenciario-bonaerense/

vii TV Pública Noticias [Televisión Pública Noticias] (25 de octubre de 2016) Vidal intervino el Servicio Penitenciario Bonaerense [ https://www.youtube.com/watch?v=146mgJ2qqMI].

viii Magister en Derecho Administrativo y se desempeñó anteriormente como Coordinador General de Gestión de la Asesoría General de Gobierno de la provincia de Buenos Aires. También fue concejal de la localidad bonaerense de San Martín por Unión-Pro durante el período 2009-2013.

ix Infocielo.( 24 de abril de 2018). Vidal Designó al nuevo interventor del servicio penitenciario bonaerense. Recuperado

https://infocielo.com/nota/90939/vidal designo al nuevo interventor del servicio penitenciario bonaere nsel,

$x$ Todo Noticias. (4 de noviembre de 2014). Furia en Palermo. Recuperado de http://tn.com.ar/policiales/furia-en-palermo-como-estacionaron-en-su-garaje-les-destrozo-el-auto-con-unhacha 542255

xi Todo Noticias. (5 de noviembre de 2014). El loco del hacha de Palermo estuvo preso y cumple dos probations. Recuperado de http://tn.com.ar/policiales/el-loco-del-hacha-de-palermo-estuvo-preso-ycumple-dos-probations 542605

xii Su primer ejemplar apareció el 02/03/1884, se edita en la Ciudad de La Plata, Capital de la Provincia de Buenos Aires. Fue fundado por Manuel Lainez, Arturo Ugalde, Martín Biedma y Julio Bonet. Tuvo como primer editor a José María Mendía. En 1889 marcó un récord de tirada para la época: la cantidad de ejemplares editados era equivalente al total de la población de la ciudad. Hugo Stunz (padre) dirigió el periódico en dos etapas (1894-1900 y 1918-29); luego su hijo asumió la conducción en 1932. Este medio cuenta con una tirada de 38.000 ejemplares. Desde 1961 hasta 1974 fue dirigido por David Kraiserburd, actualmente ese rol lo desempeña su hijo Raúl (PK). Hasta 2008 conservó un diseño sábana tradicional, tras realizar una consulta entre sus lectores, la empresa lo reemplazó por un formato tabloide. (El Día Argentina (sin fecha) en Fundación Konex. Recuperado el día 17/11/2018) https://www.fundacionkonex.org/b1618-diario-el-dia-la-plata

xiii El Día. (2 de septiembre de 2016). Imágenes de terror en Berisso. Recuperado de https://www.eldia.com/nota/2016-9-2-imagenes-de-terror-en-berisso-apunalo-a-4-personas-en-plena-calle xiv Diario Hoy. (3 de septiembre de 2016). Loco del cuchillo apuñaló a cuatro personas en Berisso. Recuperado en https://diariohoy.net/trama-urbana/loco-del-cuchillo-apunalo-a-cuatro-personas-enberisso-76643

xv Filosofía aquí y ahora José Pablo Feinmann despliega las propuestas de los grandes pensadores de todos los tiempos y presenta sus escritos esenciales para pensar la historia del mundo y de la actualidad desde un marco filosófico. Un abordaje didáctico y desde la particular mirada de este escritor, filósofo, guionista. Pensadores universales, las bases del pensamiento argentino y el latinoamericano, las ideas en torno a los derechos humanos, los movimientos políticos de la Argentina del siglo XX y mucho más. (Filosofía aquí y ahora (Sin fecha) En Encuentro. Recuperado el 17/11/2018. Disponible en http://encuentro.gob.ar/programas/serie/8011) 
xvi “El Tío Tom es el personaje protagonista de la novela de Harriet Beecher StoweLa cabaña del tío Tom (UncleTom'sCabin), en la que se narra la triste historia de un esclavo bueno y su familia, quienes a pesar de las múltiples desgracias que les acontecen siguen siendo buenos cristianos y aceptan su destino y su situación con respecto a los blancos.". Fuente: Wikipedia (Sin Fecha) Tío Tom, recuperado el 26 de julio de 2018 de https://es.wikipedia.org/wiki/T\%C3\%ADo Tom

xvii Chomsky, N. Sin Fecha. 10 Estrategias de manipulación mediática. Recuperado de https://www.revistacomunicar.com/pdf/noam-chomsky-la-manipulacion.pdf

xviii Mephystoles [Mephystoles] (1 de junio de 2015) Feinmann, José Pablo, Filosofía aquí y ahora, capítulo 1 sobre Michel Foucault, [archivo de video], recuperado de: https://www.youtube.com/watch?v=oIpyDIA gE

xix Julian Paul Assange (n.Townsville,Queensland, 3 de julio de 1971), ${ }^{1}$ conocido como Julian Assange, es un programador,ciberactivista,periodista y activista de Internetaustraliano y nacionalizado ecuatoriano, conocido por ser el fundador, editor y portavoz del sitio webWikiLeaks. Fuente: Julian Asange (sin fecha) en Wikipedia, Recuperado el 26 de julio de 2018 de https://es.wikipedia.org/wiki/Julian Assange $\mathrm{xx}$ "Criminólogo y penalista italiano, fue autor de referencia por casi tres décadas en el ámbito de la criminología, el derecho penal contemporáneo, los derechos humanos, la filosofía y la sociología del derecho. Formador de ideas en torno a la "criminología crítica", Baratta señaló que el sistema punitivo produce más problemas de los que intenta resolver, y que reprime conflictos en lugar de resolverlos. Este académico sostuvo asimismo que, por su estructura organizativa y por su modo de funcionar, el sistema penal es absolutamente inadecuado para realizar las funciones socialmente útiles declaradas por parte de su saber oficial; es decir, aquellas que se encuentran en el centro de la ideología de la defensa social y de las teorías utilitarias de la pena. Se desempeñó como profesor titular en la Universität des Saarlandes de Alemania hasta su muerte, en junio de 2002.".

Fuente: Siglo XXI Editores (Sin fecha) Autores. AlessandroBaratta. Recuperado de http://www.sigloxxieditores.com.ar/fichaAutor.php?idAutor=983

xxi La guía (12 de abril de 2013) Ley Blumberg. Recuperado de https://derecho.laguia2000.com/derechopenal/ley-blumberg

xxii Página 12 (26 de septiembre de 2008) Vidas robadas. Recuperado de https://www.pagina12.com.ar/diario/suplementos/las12/subnotas/4397-446-2008-09-29.html

xxiii El Trece TV (14 de agosto de 2008) Cuestión de peso logró que se apruebe la "Ley de Obesidad". Recuperado de

https://www.eltrecetv.com.ar/cuestion-de-peso-2008/cuestion-de-peso-logro-que-se-apruebe-la-leyde 002059

xxiv xxiv(Landshut, actual Alemania, 1804 - Nuremberg, id., 1872) Filósofo alemán. Abandonó sus estudios de teología para estudiar filosofía en Berlín junto a Hegel, a quien más tarde se opondría. Centró sus intereses en la elaboración de una interpretación humanística de la teología, en obras como Pensamientos sobre la muerte y la inmortalidad (1830) y La esencia del cristianismo (1841), su obra más destacada, en la que considera a Dios como una hipóstasis del hombre. Definido en términos abstractos pero pensado como ente sensible, Dios es en sí mismo una noción contradictoria según Feuerbach; su filosofía trata de reconducir esta y otras «espiritualizaciones» a la realidad del "hombre singular», el hombre físico, con sus sentimientos y necesidades concretas. Ludwig Feuerbach es una de las principales figuras del llamado «hegelianismo de izquierdas». Fuente: Ludwig Feuerbach (Sin Fecha) en

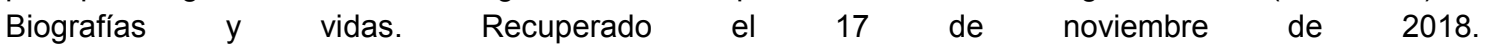
https://www.biografiasyvidas.com/biografia/f/feuerbach.htm

xxv (Buenos Aires, 1877 - 1925) Filósofo argentino. Estudió medicina en la Universidad de Buenos Aires, y fue profesor de psicología experimental en esa universidad. Está considerado como uno de los máximos representantes del positivismo en Latinoamérica.

Escribió su tesis doctoral, La simulación en la lucha por la vida (1903), en clara consonancia con la corriente darwinista que prevalecía en Argentina por aquella época. A ese respecto, y como miembro del Partido Socialista, defendió también la idea de que la lucha de clases era una de las múltiples manifestaciones de la lucha por la vida.

Fuente: Biografías y vidas (Sin Fecha) José Ingenieros. Recuperado el 26 de julio de 2018 de https://www. biografiasyvidas.com/biografia/i/ingenieros.htm

xxvi En la reglamentación de la Ley, se utiliza la nomenclatura "sufrimiento psíquico". En el Plan Nacional de Salud Mental, se retoma en el prólogo, la nominación de "persona con padecimiento mental", explicando que se utiliza para desterrar la noción de "enfermo mental", asimismo, en el documento 
mencionado, se tomará la acepción de "procesos de atención" en lugar de "tratamiento" para separar a la enfermedad -en tanto se piensa como un objeto ficticio- de la integralidad del sujeto.

xxvii Berisso es la ciudad cabecera del partido homónimo de la provincia de Buenos Aires, Argentina.

Fuente: https://es.wikipedia.org/wiki/Berisso

xxviii El Día (2 de septiembre de 2016) Imágenes de terror en Berisso. Recuperado de https://www.eldia.com/nota/2016-9-2-imagenes-de-terror-en-berisso-apunalo-a-4-personas-en-plena-calle xxix (El Día (2 de septiembre de 2016) Terror en Berisso: un hombre apuñaló a cuatro personas y fue detenido, Recuperado en https://www.facebook.com/eldialp/posts/1142170092493142)

xxx El Día (4 de septiembre de 2016) Es inimputable el acuchillador de Berisso, Recuperado en https://www.eldia.com/nota/2016-9-4-es-inimputable-el-acuchillador-de-berisso

xxxi El Día (8 de septiembre de 2016) El acuchillador de Berisso ya está en un neuropsiquiátrico, recuperado de https://www.eldia.com/nota/2016-9-8-el-acuchillador-de-berisso-ya-esta-en-unneuropsiquiatrico

xxxii Diario Hoy (4 de octubre de 2016) Loco del cuchillo: el acusado es psicótico y tiene delirios místicos. Recuperado en https://diariohoy.net/trama-urbana/loco-del-cuchillo-el-acusado-es-psicotico-y-tienedelirios-misticos-79346

xxxiii Diario Hoy (10 de octubre de 2016) "Loco del cuchillo", absuelto por inimputable. Recuperado de https://diariohoy.net/trama-urbana/loco-del-cuchillo-absuelto-por-inimputable-81024

xxxiv Diario Hoy (16 de febrero de 2018) En diciembre será el juicio al "Loco del cuchillo". Recuperado de https://diariohoy.net/trama-urbana/en-diciembre-sera-el-juicio-al-loco-del-cuchillo-116147

xxxv El Día (2 de noviembre de 2018) Declararon inimputable al joven que atacó a 4 vecinos. Recuperado de https://www.eldia.com/nota/2018-11-2-3-56-27-declararon-inimputable-al-joven-que-ataco-a-4-vecinospoliciales

xxxvi Comisión Interministerial en Políticas de Salud Mental y Adicciones (CONISMA), más información disponible en: http://adesam.org.ar/tag/comision-nacional-interministerial-de-politicas-de-salud-mental-yadicciones/ 